NBER WORKING PAPER SERIES

\title{
LAW AND EMPLOYMENT: \\ LESSONS FROM LATIN AMERICA AND THE CARIBBEAN
}

James Heckman

Carmen Pagés

Working Paper 10129

http://www.nber.org/papers/w10129

\section{NATIONAL BUREAU OF ECONOMIC RESEARCH 1050 Massachusetts Avenue Cambridge, MA 02138}

December 2003

We thank Ricardo Avelino, Giuseppe Bertola, John Donohue, David Bravo, Fernanda Ruiz, Jagadeesh Sividasan, Sergio Urzua, and two anonymous referees for helpful comments. Heckman.s contribution to this work was supported by the American Bar Foundation. The views expressed in this paper are those of the authors and not necessarily those of the Inter-American Development Bank or its board of directors. The views expressed herein are those of the authors and not necessarily those of the National Bureau of Economic Research.

(C2003 by James Heckman and Carmen Pagés. All rights reserved. Short sections of text, not to exceed two paragraphs, may be quoted without explicit permission provided that full credit, including (C notice, is given to the source. 
Law and Employment: Lessons from Latin America and the Caribbean

James Heckman and Carmen Pagés

NBER Working Paper No. 10129

December 2003

JEL No. K31, L50

\title{
ABSTRACT
}

This paper summarizes the main lessons learned from Law and Employment: Lessons from Latin America and the Caribbean, a forthcoming NBER book. It places Latin American economies and economic policies in a world context. The paper quantifies the cost of regulation in Latin America and OECD Europe and discusses the origin of regulation. It shows the fragility of time series data analyses of the sort widely used to analyze the impact of regulation in OECD Europe and the benefits of using microdata data. The evidence shows that regulation reduces labor market flexibility, reduces the employment of marginal workers and generates inequality in the larger society.

\author{
James Heckman \\ Department of Economics \\ University of Chicago \\ 1126 East $59^{\text {th }}$ Street \\ Chicago, IL 60637 \\ and NBER \\ j-heckman@uchicago.edu \\ Carmen Pagés \\ Inter American Development Bank \\ 1300 New York Avenue \\ Washington, DC 20057 \\ carmenpag@iadb.org
}


Law \& Employment: Lessons From Latin America and The Caribbean Table of Contents

1. Law and Employment: Lessons From Latin America and The Caribbean. An Introduction

By James Heckman and Carmen Pagés

2. Measuring the Impact of Minimum Wages: Evidence from Latin America By William F. Maloney and Jairo Nuñez Mendez

3. Labor Market Reforms and their Impact over Formal Labor Demand and Job Market Turnover: The case of Peru

By Jaime Saavedra and Máximo Torero

4. The Effect of Job Security Regulations on Labor Market Flexibility: Evidence from the Colombian Labor Market Reform

By Adriana Kugler

5. Determinants of Labor Demand in Colombia: 1976-1996.

By Mauricio Cardenas and Raquel Bernal

6. The Impact of Regulations on Brazilian Labor Market Performance

By Ricardo Paes de Barros and Carlos H. Corseuil

7. The Effect of Labor Market Regulations on Employment Decisions by Firms: Empirical Evidence for Argentina

By Guillermo Mondino and Silvia Montoya

8. Who Benefits from Labor Regulation? Chile 1960-1998.

By Claudio E. Montenegro and Carmen Pagés

9. Unions and Employment in Uruguay

By Adriana Cassoni, Steven G.Allen and Gaston J. Labadie 
10. Labor Market Policies and Employment Duration: The Effects on Labor Market Reform in Argentina

By Hugo A. Hopenhayn

11. Labor Market Regulation and Employment in the Caribbean

By Andrew Downes, Nlandu Mamingi and Rose-Marie Antoine

12. Labor Demand in Latin America and The Caribbean: What Does it Tell Us?

By Daniel S. Hamermesh 


\section{Introduction}

This book uses microdata from diverse Latin American and Caribbean countries to investigate the impact of regulation on their labor markets. Common methodologies are applied to extract empirical regularities from the region. Latin America and the Caribbean are of interest in their own right. But for several reasons, the lessons learned from studies of these labor markets have much greater generality.

The shifts in the policy regimes experienced in the region are dramatic by OECD standards, and many of these regime shifts are exogenous. This large and exogenous variation provides identifying power not available to analysts studying regulation in Europe and North America. Given the evidence on the comparability of labor demand functions around the world summarized in Hamermesh (1993 and this volume), lessons about the impact of regulation learned from Latin labor markets apply more generally.

The studies in this volume are based on microdata. Use of such data avoids reliance on fragile country aggregate statistics that have been the main source of information used to study European regulation (see, e.g. the evidence summarized in Nickell and Layard, 1999). Countries have diverse economic regions and agents and aggregation over these regions and their economic agents masks this diversity. In this chapter, we show the sensitivity of estimates of the impact of regulation obtained from conventional pooled time series-cross sections of countries to alternative choices of samples and models, although a few important empirical regularities established at the microlevel hold up in macrodata. Our analysis builds the case for doing disaggregated analyses of the type reported in this book.

The evidence presented here challenges one prevailing view that labor market regulations affect only the distribution of labor incomes and have minor effects on 
efficiency. ${ }^{4}$ The results presented in this volume suggest that mandated benefits reduce employment and that job security regulations have a substantial impact on the distribution of employment and on turnover rates. The most adverse impact of regulation is on youth, marginal workers, and unskilled workers. Insiders and entrenched workers gain from regulation but outsiders suffer. As a consequence, job security regulations promote inequality among demographic groups. Most of the individual country studies demonstrate that regulations promoting job security reduce covered worker exit rates out of employment and out of unemployment, and on net reduce employment.

This introductory essay has three main goals. (1) It summarizes the main lessons to be drawn from the studies assembled here. (2) It places Latin American and Caribbean (LAC) regulatory burden in an international context by comparing the level and changes in LAC labor regulation policies with those in OECD countries as well as providing some historical context about the origins of this regulation. (3) It updates the work of Heckman and Pagés (2000) with an expanded sample and better measures of regulation, providing a cross-country time-series analysis of the impact of regulation on employment and unemployment. We quantify the cost of regulation in LAC and OECD region. The fragility of the macro-based estimates documented in our paper suggests one reason why relatively little is known about the impact of regulations in Europe despite an abundance of crosscountry time-series papers analyzing policies in that region. However, the macro timeseries literature does produce some empirical regularities. The methods used to analyze the micro-evidence presented in this book should be extended to produce more convincing evidence of the impacts of regulations on employment in the OECD region ${ }^{5}$.

\footnotetext{
${ }^{4}$ Freeman (2000) and Nickell and Layard (1999), among others, adopt this view.

${ }^{5}$ See, however, the studies of Abowd et al. (1997, 1999, 2000), Machin and Stewart (1996), Kugler, Jimeno and Hernanz (2002) and others, who use microdata to investigate the impact of regulation in Europe.
} 
This Chapter proceeds in the following way. Section 2 provides background on Latin American economic and labor market performance. Section 3 presents some basic facts about regulation in LAC, and compares LAC with OECD countries both in terms of the level and composition of labor cost and in terms of the labor market reforms experienced in the region. Section 4 summarizes the main lessons from the essays presented in this book. Section 5 updates Heckman and Pagés (2000) and uses the cost measures derived in Section 3 to examine the impacts of labor regulation on Latin American and OECD employment and unemployment rates. Section 6 concludes and makes suggestions for future work on regulation in Latin American and OECD labor markets. We first present some background on Latin America and the nature of labor market regulation in the region.

\section{Latin American Economic and Labor Market Performance}

Latin American economic performance has been quite disappointing. Since 1970, growth of income per capita has been just over one percent a year, higher than in Africa or the Middle East, but much lower than in Asia or in the developed countries (Figure 1). Up to the 1980 s, trade policies heavily protected Latin economies from foreign competition. There was a substantial degree of intervention by the state in the economy. The collapse of most economies during that decade due to growing fiscal and monetary imbalances led many countries to implement large structural reforms towards the end of the 1980s and early 1990s. Macroeconomic stabilization policies reduced fiscal deficits and brought inflation under control. Sweeping, fast-paced trade reforms lowered substantial tariff barriers on manufactured goods. Governments undertook fiscal reforms, lifted control over financial markets and privatized most state-owned firms. Some countries also embarked on 
labor reforms described in the next section. While growth rates in the 1990s were higher than they were during the 1980s, the rates of growth in this period still fell short of those attained in other parts of the world.

Among the countries covered in this volume (Argentina, Brazil, Chile, Colombia, Peru, Uruguay, Barbados, Jamaica and Trinidad and Tobago), Chile was the best performer, with an average growth rate of GDP of 4.8 during the period 1980-2001 (see Table 1). Argentina and Trinidad and Tobago experienced the lowest average growth during the past two decades, despite high average growth rates during the nineties.

In spite of this weak economic performance, GDP per capita (PPP US\$ adjusted) levels in Latin American countries are higher than those of other developing regions. According to the World Bank Development Indicators, in 2001, the average GDP per capita in the Latin America and the Caribbean region was $\$ 7,050$, considerably higher than that of East Asia and the Pacific (4,233), Central and Eastern Europe (6,598), South Asia (2,730), Sub-Saharan Africa $(1,831)$ or the Arab States $(5,038)$. Similarly, the regional Human Development Index computed by the United Nations for LAC (0.77) was almost as high as in Central and Eastern Europe (0.78) and higher than in any other region except for the OECD (0.90). Among the countries whose labor markets are analyzed in this volume, Barbados and Argentina exhibited the highest income per capita and human development indexes while Jamaica and Peru rank the lowest among the countries both in per capita income and in human development (see Table 1).

While GDP growth rates were not high, during the period 1980-1999 employment rates grew in the nine countries studied here. The highest growth rates were recorded in Colombia and Peru, countries that also experienced fast growth in female labor force participation. In contrast, average employment growth rates were low in Trinidad and 
Tobago and in Argentina. According to International Labor Organisation (ILO) and Economics Commission For Latin America and The Caribbean (ECLAC) data, average urban unemployment rates during the eighties and nineties exceeded 8 percent in all countries analyzed in this book except for Brazil. Unemployment comparisons should be treated cautiously because they are not strictly comparable. For instance, in the Caribbean countries, the unemployment rates include discouraged workers (those who drop out of the labor force), while such workers are excluded in the Latin American countries, which compute unemployment rates according to more traditional definitions. ${ }^{6}$ Many have remarked that the high level of regulation of economic activity in the region accounts for problems in the labor markets in the region, and the essays assembled here shed light on this conjecture.

\section{Labor Market Regulations and Institutions in Latin America and the Caribbean}

This section sketches the history of labor market regulation in the region and describes and quantifies the regulatory environment in Latin America and the Caribbean. It compares the level of regulation and pace of regulatory reform in LAC countries and OECD countries. When it is credible to do so, we also make an effort to quantify the monetary costs (as a percentage of wages) of full compliance with regulations without discussing whether costs are borne by workers or firms. We discuss this issue more extensively in sections 4 and 5.

\section{Regulations governing individual contracts}

\footnotetext{
${ }^{6}$ That is, they only include persons that are available for work and who are taking specific steps to search for a job.
} 
Throughout Latin America, labor codes determine the types of contracts, the lengths of trial periods, and the conditions of part-time work. Regulations favor full-time, indefinite contracts over part-time, fixed-term or temporary contracts. As a form of worker protection, labor codes mandate a minimum advance notice period prior to termination, specify which causes are considered justified causes for dismissal, and establish compensation to be awarded to workers depending on the reason for the termination. In contrast, temporary contracts can be terminated at no cost provided that the duration of the contract has expired. To prevent firms from exclusively hiring workers under temporary contracts, in most countries the use of such arrangements is severely restricted. Labor codes also limit trial periods - that is, the period of time during which a firm can test and dismiss a worker at no cost if his or her performance is considered unsatisfactory.

Although most OECD countries began regulating their labor markets when they had attained relatively high income per capita, Latin America and other developing countries started regulating their markets much earlier in the development process (Lindauer, 1999). The first regulations date from the beginning of the twentieth century. The motivation for these regulations was the perceived need to protect the welfare of workers against the excessive power of employers, and to insure workers against the risk of job loss and income security (Lindauer, 1999). The Mexican constitution of 1917 articulated the principle that protecting workers was one of the duties of the State. By the 1930s and 1940s most countries had a Labor Code. The belief that each new reform should only strengthen the set of warranties and benefits awarded from previous laws became widespread. For many years, successive reforms expanded the protection that the law afforded to workers. There was little examination of the question whether such regulations would affect economic performance. However, until the 1980s most countries in the LAC 
region were isolated and their industries heavily protected. Labor regulations were one way to distributing the rents from protection among covered workers and employers. Regulations are a low cost way (from the point of government fiscal authorities) of providing social insurance to protect workers. The weak fiscal systems in place in the region joined with the low level of income and a tradition of tax evasion, corruption and noncompliance made the social insurance schemes used in more developed countries prohibitively costly.

Military rule often led to deregulation of many labor markets. Unions were frequent targets, as much for political as for economic reasons. The political and economic environment in LAC changed substantially in the 1980s and 1990s. Most countries restored democracy after long periods of military rule. These political changes bred some labor reforms, first to restore union activity, which had been made illegal in many military regimes, and second to reach a new social pact. In Chile, Brazil and the Dominican Republic, at the beginning of the 1990s and later in Nicaragua (1996) these reforms produced more protective labor regulations.

A new Constitution was enacted in 1988 in Brazil as part of the process of redemocratization during the second half of the 1980s (See Paes de Barros and Corseuil, this volume). This new Constitution revised labor regulations and changed many labor codes that had been in place since the 1940s. The new Constitution reduced the maximum working hours per week from 48 to 44 hours; reduced the maximum number of hours for a continuous work shift from 8 to 6 hours; increased the minimum overtime premium from 20 percent to 50 percent; increased maternity leave from 3 to 4 months; and the value of paid vacations increased from 1 to, at least, $4 / 3$ of the normal monthly wage. The new Constitution also modified the mandatory individual saving accounts system created in 
1966. Prior to the reforms, the law required employers to deposit 8 percent of employees' wages in a worker-owned account. In case of separation, workers could withdraw the accumulated funds (plus the interest rate). In addition, if a firm initiated a separation it had to pay a penalty equivalent to 10 percent of the amount accumulated in the account. As part of the 1988 reform, this penalty was increased to 40 percent, considerably increasing the cost of dismissing a worker.

In the case of Chile, the 1990 reform introduced with the return to democracy reestablished some of the protection to workers that had been eliminated during the military regime. Under the dictatorship, union activity had been severely restricted and some benefits, such as indemnities for dismissal had been substantially reduced. ${ }^{7}$ See Montenegro and Pagés (this volume). In 1990, the new law increased maximum indemnities from 5 to 11 months of pay. It also re-introduced the need for firms to prove just cause for dismissal, although unlike the case in other countries, the new law considered the economic needs of the firm a just cause.

While in some countries lawmakers were busy increasing legal protection for workers, the economic environment was changing substantially. The deep economic crisis that ensued with the Debt Crisis of the early 1980s called into question the protectionist model. The relatively good performance of the Chilean economy, which in the mid 1970s opened to trade and introduced many pro-market reforms, spawned imitators all across Latin America. By the second half of the 1980s and the early 1990s, most countries had drastically reduced tariffs on imports. The new openness to international trade increased the demand for labor market flexibility. It was argued that without sweeping labor market reforms, Latin American economies would not be able to compete internationally. This

\footnotetext{
${ }^{7}$ See Montenegro and Pagés, this volume.
} 
was the main motivation behind the reforms that introduced temporary contracts in Argentina, Colombia, Ecuador, Nicaragua and Peru and that reduced the cost of dismissing workers with indefinite contracts in Colombia (1990) and Peru (1991). Temporary and fixed-term contracts were introduced in Argentina in 1991 and their role was expanded in 1995 (See Hopenhayn, this volume). These changes were influenced by similar reforms in Spain during the 1980s. Special fixed-term duration employment promotion contracts could be awarded to unemployed workers and to workers younger than 25 and older than 40 years old. For some types of contracts, severance pay was reduced by 100 percent. However, these contracts were eliminated in 1998, when the share of persons working under these arrangements had increased substantially. Ecuador, Peru and Colombia also lifted restrictions on the use of these types of programs in the early 1990s. In Peru, the number of workers hired under these contracts increased enormously. In Brazil, the use of such contracts has been liberalized since 1998 .

The 1991 reforms in Peru reduced the cost of dismissing workers hired under indefinite contracts. During 1971-1991, workers who had completed trial periods were granted permanent job security. If a firm dismissed a worker and could not prove "just cause" in labor courts, the worker could choose between being reinstated in his or her job or receiving a severance payment of three monthly wages per year of work (with a maximum of 12 months pay). In practice, since workers could always ask to be reinstated and then settle for a higher severance pay, the mandatory amount was a lower bound of the firing cost. See Saavedra and Torero (this volume).

Beginning in 1991, workers hired after that year could be dismissed at will upon payment of a severance benefit. In addition, "just cause" clauses were extended to allow the dismissal of workers who did not perform up to expectations. The severance pay 
schedule was reduced from three to one wage for every year of tenure for workers with more than one year in the firm, with a minimum of three wages and a maximum of twelve. The 1993 Constitution replaced the right of workers to a permanent job with the right of firms to dismiss workers. In July 1995, a second wave of labor reforms, simplified the severance payment to one month per year of work up to a maximum of 12 months and the two-tier severance system was eliminated. These modifications substantially reduced the cost of dismissing workers. However, in November 1996, the severance payments rule was increased again to one and a half wages per year of work with an unaltered maximum cap of twelve wages.

In Colombia, the 1990 Labor reforms liberalized many aspects of labor regulation. Besides regulations introducing the use of temporary contracts, the most important changes were those in the Cesantias, or severance pay that firms owed to workers at the end of the work relationship regardless of the cause or the party that initiated separation. Prior to the reforms, employers were mandated to pay severance of one month per year at the time of the separation based on the salary at the separation. Workers could obtain advanced payments against their benefits. Such withdrawals were credited against the severance pay due workers at the end of the labor relationship in nominal terms as of the date of the withdrawal. High rates of inflation increased the costs of such schemes to employers. After the reform, the withdrawals were credited in real terms, substantially reducing costs for firms. In addition, the reforms eliminated the right to re-instatement for workers with more than ten years of tenure. Offsetting these cost-reducing features, the reforms increased the cost of indemnities for dismissal.

Panama (1995) and Venezuela (1997) also undertook labor reforms with the goal of increasing labor market flexibility while preserving some form of protection to workers. 
In both countries reforms increased mandatory pay in case of separation, but considerably reduced the additional amount that firms had to pay in case of a firm-initiated dismissal.

In contrast to Latin American regulation, in the Caribbean a mixture of legislation, common law doctrines, custom and policy characterizes the institutional context. At the beginning of the Twentieth Century, in all countries of that region, regulation of the labor market was based on common law rather than on the Civil Law tradition predominant in Latin America (see Downes, Mamingi and Antoine, this volume). While in some countries, like Barbados, most aspects of labor relation are still left to the courts to determine, in others, such as in Trinidad and Tobago, the enactment of different regulations has progressively increased the level of statutory protection to workers. In Barbados (1973), Trinidad \& Tobago (1974) and Jamaica (1985) labor reforms instituted mandatory severance pay, although as shown in the next section at levels that are much lower than those prevalent in Latin America.

\section{Payroll Contributions and other Mandatory Benefits}

As in most industrial countries, in LAC many social protection programs, such as old-age pensions, public health systems, unemployment subsidies, and family allowances are funded from payroll contributions. In addition, regulations mandate other employeepaid benefits such as occupational health and safety provisions, maternity and sick leave, overtime pay and vacations.

Unlike changes in labor codes that tend to be infrequent events, changes in the level of contributions to these programs occur often. In addition, during the 1990s, many countries implemented reforms, which transformed pay-as-you-go systems into full or partial capitalization systems. One of the advantages of such schemes is that they tend to 
increase the link between contributions and benefits. However, at the same time, many countries, most noticeably Colombia, El Salvador, Mexico, Uruguay, and Brazil, increased the level of payroll taxes to reduce the actuarial imbalances present in their social security systems. Below, we quantify the levels and changes in these contributions across Latin America and OECD countries.

\section{Collective Bargaining}

Unions in Latin America tend to be firm or sector-based and weak. In most cases, the state intervenes in union registration and accreditation as well as in the process of collective bargaining. The state authorizes only certain unions to have representation authority (Argentina, Mexico, Peru, Brazil), and intervenes in the resolution of conflicts and the arbitration process (Argentina, Mexico). Only in Brazil and Argentina is collective bargaining highly centralized at the sector level, while in Nicaragua and Colombia, sectorlevel bargaining coexists with firm-based negotiation. In Mexico, collective bargaining takes place at the firm level but a high level of centralization is achieved through a strong corporatist structure and through union discipline (O'Connell, 1999). In contrast, unions are stronger and collective bargaining tends to be national or sector-based in OECD countries with the exception of Canada, New Zealand, the United Kingdom and the United States.

According to data from ILO (97-98), union density as percentage of nonagricultural employment is higher in Brazil, Mexico, Argentina and Nicaragua and smaller in the rest of the Latin American countries. Union affiliation tends to be higher in countries where collective bargaining is more centralized. Overall, union density is lower in Latin 
America (14.7) than in industrial countries (36.6). ${ }^{8}$ There are also large differences in coverage rates. Thus, while collective bargaining agreements in countries such as Spain, France and Greece, which are negotiated by a minority, are extended to almost all employees, in Latin American countries this is generally not the case. As a result, coverage rates in Latin America tend to be much lower than those observed in OECD countries with similar affiliation rates.

The influence that collective bargaining exerts on wage and employment conditions, measured by affiliation rates, is declining over time. Thus, Latin American and Caribbean countries share a trend that has been well documented for OECD countries. Affiliation rates have declined in all of the countries of the region. ${ }^{9}$ This decline has been especially large in Mexico, Argentina, Venezuela, Costa Rica and Uruguay. In this chapter, we only present estimates for Uruguay on the impact of unionization on employment. Cassoni, Allen and Labadie (this volume) estimate a strong adverse impact of unionism on employment in Uruguay. The evidence for other Latin American countries is still too sparse.

\section{Minimum Wages}

Minimum wages are widely used in Latin America to increase the wages of the poorest workers. Figure 2 (taken from Maloney and Nuñez-Mendez, this volume) ranks various Latin American and OECD countries by their minimum wage, standardized by the

\footnotetext{
${ }^{8}$ ILO data corresponds to the mid nineties. The comparison between LAC and Industrial countries reflects the difference between unweighted regional averages. The average for industrial countries includes the following countries (France, Spain, US, Greece, Germany, Italy, UK, Denmark, Belgium, Finland, Iceland, Ireland, Sweden and Canada)

${ }^{9}$ ILO data for 1985 and 1993 indicates that union affiliation increased in Chile during that period. Yet, data from a later period indicates that union affiliation has been declining since 1993 .
} 
mean wage ${ }^{10}$ While some Latin American countries appear in the lower range of this distribution, most notably Uruguay, Bolivia, Brazil, Argentina, Chile and Mexico, others, such as, Venezuela, El Salvador, Paraguay and Honduras have very high minimum to average minimum wages by OECD standards. These high levels suggest that minimum wages are likely to be binding, and, as a result, to reduce employment, and to retard downward wage movements in the presence of adverse demand shocks.

Data on enforcement of the minimum wage is incomplete. However, some evidence available for workers between 25 and 40 years old suggests that about 10 percent of wage employees in that age range earn salaries below the minimum wage (See Table 2). In some countries, such as Mexico, Uruguay, Bolivia and Argentina, the proportion below the minimum in this age range is very small. In other countries, such as Colombia, minimum to average wages are high but a large proportion of the labor force in the 25 to 40 age-range earns wages below the statutory minimum. Whether the adverse effect of a high level of minimum wages is offset by substantial non-compliance remains an open empirical question.

\section{What motivates reforms?}

In studying the effect of reforms in the labor market it is important to examine what factors initiate these relatively infrequent episodes. It could be argued that labor market outcomes are driven by the same events that drive the reforms, and not by the labor reforms themselves. Figures 3A-3F (for Latin America) and 3G-3I (for the Caribbean) plot GDP growth rates and unemployment rates for the countries covered in the individual

\footnotetext{
${ }^{10}$ The observations are from the early nineties for the OECD countries and from the mid and late nineties for LAC. Data from OECD were obtained from Dolado et al (1996), data from LAC comes from IADB (19981999) and Maloney and Nuñez.
} 
country studies of this volume during the period 1980-2000. They also plot major episodes of labor reform (marked with a continuous line if a liberalization of the labor market occurred and dotted line if the reforms increased protection to workers). ${ }^{11}$ In addition, these figures mark episodes of major tariff reductions (double line) or the end of military regimes and the return to democracy (discontinue line).

In Argentina, Colombia, Peru, and Uruguay, reforms that liberalized the labor market occurred within one or two years before or after major reductions in tariffs, and were part of efforts to liberalize economies and increase the participation of the market in the production and allocation of goods and services. In Chile and Brazil, reforms that increased the legal protection of workers occurred in the context of a transition to democracy. In all of these episodes it could be argued that labor reforms were exogenous to the economic system since they were driven either by a new economic philosophy or by profound transformations in political regimes, although one could counter that these political transitions were facilitated by economic developments. Some reforms and transformations are clearly driven by changes in economic activity. There is evidence that many reforms tend to occur around periods of negative economic growth. In the countries and periods analyzed in this volume, there have been at least 15 episodes of reform. Out of these fifteen, six episodes of reform occurred in years in which GDP had declined the year before. However, four of those reforms increased the legal protection to workers and two liberalized the labor market.

Overall there is no empirical relationship between labor reforms and labor market outcomes driven by economic performance. Our cross-country time-series analysis

\footnotetext{
${ }^{11}$ Only major changes in labor codes or other major government interventions in the labor market are included. Changes in social security contributions or payroll taxes, as well as changes in the level of minimum wages -which occur quite frequently-- are not included.
} 
presented in this chapter controls for present and past levels of economic activity, to account for the possibility of endogeneity. The disaggregated studies use year effects and other strategies to control for endogeneity.

\section{Quantifying the Cost of Regulation}

This section constructs measures of labor laws that can be compared across countries and time (see also Heckman and Pagés, 2000). Many studies that summarize institutional data across countries construct qualitative indices that rank variables across countries. For instance, Grubb and Wells (1993) construct a series of indicators of employment protection by ranking different aspects of job protection across countries and averaging these different rankings in one summary indicator. Although such measures summarize many complex institutional features, they are not comparable over time. A second group of studies constructs measures that aggregate institutional aspects of the labor market by assigning to each country/year a value in a certain range, for instance, between zero and one. These measures summarize a large number of interesting aspects and are comparable across time. However, they can also be quite arbitrary since it is difficult to justify any assigned numerical values for qualitative variables and it is difficult to compare one measure against another. Moreover, the measures are very sensitive to the weights assigned to the different components of these measures. From a policy standpoint, summarizing many features of a regulatory system in one indicator makes it impossible to distinguish which components, if any, have an adverse effect on employment.

We take a different route by constructing measures of the direct cost (measured as a fraction of average monthly wages) of complying with labor laws. These measures can be compared not only across countries and over time, but they can also be compared against 
each other. This allows us to quantify, for instance, the share of the total costs given by each type of regulation. Our measure of mandatory total costs $(T C)$ of regulations is:

$$
T C=S S P+J S
$$

It is the sum of the cost of social security payments $(S S P)$ plus the cost of abiding by job security provisions $(J S)$. These costs are expressed as fractions of the average monthly wage.

This measure of the cost of regulation omits some important components of labor cost. For example, the costs of abiding by certain laws are hard to quantify and are omitted. One example of laws whose costs are difficult to quantify, is the prohibition against dismissing workers in bad times. In addition, this measure does not include the cost of regulating the length of the standard workweek and overtime work. It does not include the cost of complying with minimum wage laws or other income floors. We do not include regulations on temporary labor contracts. Although these regulations are likely to have effects on employment and unemployment, we choose to exclude them because comparable data on the share of the labor force affected by these regulations across time and countries are difficult to obtain. We leave the quantification of these features of regulations for future work.

There is one major conceptual problem with this index. It does not distinguish between static and dynamic aspects of the cost of labor. Job security affects both components of costs by raising the total cost of labor and by increasing the cost of adjusting labor. Social security costs affect the unit cost of labor without affecting dynamic costs of labor. Our index of total cost is not a measure of the price of labor facing firms at different stages of the business cycle. We develop this point below and in Appendix B. 


\section{Quantifying Job Security Provisions}

Our index includes in job security legislation those provisions of the law that increase the cost of dismissing a worker for economic reasons. ${ }^{12}$ Across countries, termination laws require firms to incur at least five types of costs: administrative procedures, advance notification, indemnities for dismissal, seniority pay and the legal costs of a trial if workers contest dismissals. Administrative procedures require the firm to notify and seek approval by labor unions or the Ministry of Labor to extend the period between layoff decisions and the actual occurrence of layoffs. They may also involve long negotiations to place workers in alternative jobs. The period of advance notification should also be included in the computation of labor costs because in many countries, laws allow firms to choose between providing advance notice or paying a compensation equivalent to the wages for the corresponding period. Moreover, since productivity declines substantially after notice, advance notification should be considered as a part of dismissal costs even when firms choose to notify workers in advance. Therefore, we assume that employees do not work at full productivity levels after notification. ${ }^{13}$ In most countries, mandatory advance notice periods increase with tenure, and in others they are higher for white-collar than for bluecollar workers.

Most Latin American and OECD countries mandate indemnities in cases of firminitiated dismissal. In general, indemnities are based on multiples of the most recent wage and the years of service. Some countries calculate the amount of mandatory indemnities based on whether the dismissal is deemed just or unjust or whether the worker is blue-

\footnotetext{
${ }^{12}$ In most countries, the law does not mandate compensation for dismissal if the separation is due to employees' misdemeanors. However, if such behavior cannot be proved, the worker has to be compensated at the regular legal rate.

${ }^{13}$ There is some evidence that advance notice stimulates on-the-job search during the notification period (Addison and Portugal 1992), which suggests a reduction in the effort devoted to work.
} 
collar or white-collar. In contrast, seniority pay is only mandated in a few Latin American countries in which the law requires employers to make a payment upon termination of the work relationship regardless of the cause or party initiating the separation. In these countries, firms initiating dismissal are required to pay both indemnities and seniority pay. In some countries, this payment is deposited as a regular contribution to the worker's individual savings account. In these countries, workers can withdraw principal and interest from their account upon separation. In other countries, seniority pay is determined as a given amount that has to be paid to the worker upon termination of the work relationship. ${ }^{14}$ Finally, firms can incur considerable additional costs if workers contest dismissal in courts. If judges rule in favor of workers, firms not only have to pay indemnities, but also the workers' foregone wages during trial.

To compute the monetary cost of labor laws, we improve on the job security measures developed in Heckman and Pagés (2000) in three ways. First, we expand our previous data base to include the 1980s in all OECD countries. This expansion of the data set allows us to capture some additional labor reforms in OECD countries not previously captured. Second, we revise and correct some of our previous data on advance notice and indemnities for a number of countries to better capture the actual cost of the law (see Appendix A for a complete description of the methodology and assumptions involved). Finally, we include the cost of seniority pay in our measure of job security, which we did not include in our previous work.

Our measure of the cost of job security $J S_{j t}$ for country $j$ at time $t$ is constructed from the following formula:

\footnotetext{
${ }^{14}$ For an extensive description of job security measures see $\operatorname{OECD}(1993,1999)$ for OECD countries and IADB (1996).
} 


$$
\begin{aligned}
J S_{j t} & =\sum_{i=1}^{T} \beta^{i} \delta^{i-1}(1-\delta)\left(b_{j, t+i}\right)+\sum_{i=1}^{T} \beta^{i} \delta^{i-1}(1-\delta)\left(a_{j} * y_{j, t+i}^{j c}+\left(1-a_{j}\right) * y_{j, t+i}^{u c}\right)+\sum_{i=0}^{T} \beta^{i} c_{j, t+i} \\
& =A N_{j, t}+I D_{j, t}+\operatorname{SenP}_{j, t} \\
& \begin{array}{l}
\text { Advanced Indemnity } \\
\text { Notice }
\end{array}
\end{aligned}
$$

where $\delta$ is the probability of a worker remaining in a job in a period, $\beta$ is the discount factor, $i$ denotes tenure at the firm, and $T$ is the maximum tenure that a worker can attain in a firm which is assumed to be twenty years $(T=20)$. The expression is broken down into three terms corresponding to advanced notice costs $\left(A N_{j, t}\right)$, indemnity costs $\left(I D_{j, t}\right)$ and seniority pay $\left(\operatorname{Sen} P_{j, t}\right)$. The first term in expression (1) is the discounted cost of future advance notice, weighted by the probability that a worker will be dismissed, after one, two, three, and so on, periods at the firm where $b_{j, t+i}$ is the advance notice to a worker who has been $i$ years at a firm measured in monthly wages. The second term in expression (1) is the discounted cost of future indemnities, weighted by the probability of dismissal after $i$ periods at the firm. In this expression, $a_{j}$ denotes the probability that the economic difficulties of the firm are considered a just cause of dismissal while $y_{j, t+i}^{j c}\left(y_{j, t+i}{ }^{u c}\right)$ is the mandated indemnity in case of just cause (unjust cause) dismissal, again measured in monthly wages. Finally, the third term in expression (1) captures the cost of severance pay, and $c_{j, t+i}$ denotes contributions to a workers' savings account measured in monthly wages. ${ }^{15}$ We assume a common discount and dismissal rate of 8 and 12 percent, respectively across countries. The choice of the discount rate is based on the historical returns of an internationally diversified portfolio. Our choice of the turnover rate is motivated by the concern that turnover rates are affected by the legislation in countries 
with job security provisions. We use a benchmark turnover rate from the United States, a country with lower job security costs than any country in our LAC sample. If intrinsic turnover in LAC is higher than in the U.S, we understate costs. The choice of this benchmark is clearly a rough way to avoid endogeneity problems. To assign values to the discounted future payments of advance notice, indemnities and seniority pay, we use the information contained in Tables A.1 and A.2 in Appendix A. When regulations mandate different provisions for white-collar and blue-collar workers, we take the unweighted average for the two types of workers.

By construction, our job security measures give a higher weight to dismissal costs that may arise soon after a worker is hired since they are discounted less at the time of hiring, while they discount more firing costs that arise further in the future. Our measure captures the expected average cost. Consequently, it does not measure the true marginal labor cost, which is state contingent, nor does it distinguish dynamic from static costs, as we have previously noted. We discuss these issues further in Appendix B.

\section{Quantifying the Cost of Social Security}

To quantify the cost of social security regulations and payroll taxation, we gather data on mandatory payroll contributions to old age, disability and death, sickness and maternity, work injury, unemployment insurance and family allowances programs. Since the nominal incidence of the contributions (whether they fall on the employer or the employee) is irrelevant in measuring total social cost (although it is not irrelevant for the study of labor demand), we add both contributions as a percentage of wages.

\footnotetext{
${ }^{15}$ In countries where the law mandates seniority pay, but this pay is not capitalized in individual savings accounts, $c_{j, t+i}$ measures the costs associated with this provision, which will arise in the future with probability one.
} 
To quantify the cost of social security provisions in a way that is comparable to the cost of job security, we compute the expected cost of social security provisions at the time of hiring as:

$$
S S P_{j t}=\sum_{i=0}^{T} \beta^{i}\left(s s_{j, t+i}^{e}+s s_{j, t+i}^{w}\right)
$$

where $s s_{j, t+i}^{e}$ and $s s_{j, t+i}^{w}$ are, respectively, the costs of payroll taxes paid by the employer and the worker expressed as a percent of wages, and $\beta$ is the discount rate. ${ }^{16}$

\section{The Cost of Labor Laws across Countries}

Table 3 summarizes our measures of the cost associated with different labor regulation regimes. In the first three columns, we summarize the cost of abiding by employment protection laws at the end of the 1990s. We generate these indices for all countries in all years for which we have data. Table 3 only reports those values for the last year of our sample. Column (1) summarizes the cost of giving advance notice to workers. In the Latin American countries, the typical required advance notice is a month or the equivalent to 0.63 monthly wages in expected value terms. Bolivia stands out as the country that requires a longer advance notice period (1.77 months in expected terms), while Peru and Uruguay require no advance notice. Mandatory advance notice provisions tend to be more stringent in OECD countries. Many OECD countries mandate fairly long advance notice periods, particularly for skilled workers. In addition, in most countries, advance notice periods increase with seniority. In Belgium, for instance, the mandatory advance notice for

\footnotetext{
${ }^{16}$ We obtain the information on these contributions from the series "Social Security Programs Throughout the World," edited by the United States Social Security Administration (1983-1999).
} 
skilled workers with 10 years of seniority is 9 months, while for workers with 20 years of seniority it is 15 months. In Sweden, all workers with 10 years of seniority are entitled to an advance notice period of 5 months, whereas for a worker with 20 years of seniority, the mandatory advance notice period is 6 months. The fact that Belgium and Sweden have very similar values in Table 3 reflects the fact that in Belgium very high advance notice only applies to skilled workers whereas in Sweden it applies to all workers. It also reflects the fact that our measure heavily discounts costs that are expected to occur far in the future. On average, mandated advance notice periods are significantly longer in OECD countries than in the Latin American and Caribbean sample.

The second column displays the cost of indemnities for dismissal. Within the LAC sample, Colombia, Peru, Ecuador, Bolivia, El Salvador, and Honduras stand out as countries where the cost of abiding by these regulations is the highest. In the sample of OECD countries, Portugal, Turkey, Korea, Italy and Spain are the ones where indemnities for dismissal laws are more costly (in terms of expected monthly wages), while a number of countries including Belgium, Finland, Germany, Japan, Netherlands, New Zealand, Norway, Poland, Sweden, Switzerland and the United States do not mandate indemnities for dismissal. Comparing the two regional samples, it is clear that, on average, compensation for dismissal is three times larger in LAC than in the OECD countries despite the much lower level of income in the LAC region.

The third column refers to seniority pay. This additional payment is mandatory in only six Latin American countries, but the estimated expected discounted costs are large when this feature is present. In Colombia, Brazil, Ecuador and Peru, employers are required to deposit about one month of pay every year to workers' individual savings accounts. Over the life of a worker, this provision is expected to cost about 10 monthly wages in these four 
countries. Once advance notice, compensation for dismissal and severance pay are added, we find that the cost of job security provisions is much higher in the poorer Latin American and Caribbean region than in the richer OECD sample.

The fourth column reports the expected costs of complying with social security laws. Compared to the costs of employment security, social security costs are very large and therefore constitute the lion's share of the total costs of labor laws. In Argentina, for example, expected discounted costs of social security are 44.5 months of pay while in many OECD countries these costs are even larger. In the average Latin American country, social security payments amount to 82 percent of the total costs of labor laws. This percentage is even larger in OECD countries where, on average, they reach 96 percent of the total regulatory costs.

Once all the costs are aggregated, labor laws impose a much larger cost in OECD countries. However, the composition of these costs is quite different. While the typical Latin American country mandates shorter advance notice periods and lower social security contributions than the average OECD country, job security provisions are substantially higher in LAC.

Latin American and Caribbean countries have a higher burden of regulations that affect adjustment processes in the labor market. European countries have a higher burden of payroll taxation that affects labor demand but not labor adjustment. Both regions have a much higher burden of labor costs than North America.

Exploring the relationship between income per capita and social protection across countries, it is clear that job security provisions are strategies of low income regions. Figure 4 graphs regression relationships for each of our measures of labor cost on GDP per capita (PPP adjusted) and GDP squared. Across countries, advance notice costs tend to 
increase with income; seniority pay and indemnities for dismissal decline with country income. Social security contributions follow an inverted U-shape pattern in income. They tend to increase with income in the Latin American sample and reach a maximum in medium income countries, while they tend to decline with income within the sample of upper-income countries. Regulation is an inferior good. It is the response of poor countries to the demand for worker security. By imposing a mandate on firms, central governments avoid the direct fiscal cost of financing social safety nets albeit at the cost of affecting their labor market performance.

We next examine the evolution of these measures over time. Since the early 80 's there have been few reforms in job security provisions in Latin America and even fewer in OECD countries. Social security contributions have changed more, but even they seldom change drastically. This lack of variability, particularly in job security provisions, poses a challenge for empirical studies of the impact of regulations. Figure 5 shows the level and the changes in job security since the late eighties across Latin American countries. The general view that there have been important reductions in dismissal costs in Latin America is not accurate once we aggregate across all components of job security. Only Colombia, Panama, Peru and Venezuela have experienced a reduction in the costs of terminating indefinite contracts. In Venezuela and Panama, the reduction in indemnities has been partly offset by increases in the costs of severance pay. Our measures reveal that Brazil, the Dominican Republic, Chile and Nicaragua undertook reforms that increased the cost of dismissal. Assembling Latin American and OECD events, there are 13 episodes in which job security provisions were changed. Nine of these episodes occurred in Latin America and four occurred in the OECD sample. Figure 6 shows the percentage change in advance notice and indemnities for dismissal in the countries that have experienced reforms. It 
makes clear that changes in job security costs have been substantial in Latin America relative to the OECD sample. The enormous variation in the Latin American region and the exogeneity of some of the reforms is the reason why we think that the study of Latin American labor markets can inform further analyses of the impacts of regulation in economies around the world.

Figure 7 reports social security contributions (measured in expected discounted cost terms) at the beginning and at the end of the nineties for Latin American Countries. There have been important changes during the last decade. In many countries, social security contributions increased during the nineties as a consequence of pension reforms and population aging. Yet, in some countries, most significantly in Argentina, social security contributions were reduced during the decade.

\section{Enforcement and Informality}

The measures summarized in Table 4 calculate de jure cost of regulations, assuming that firms and workers abide by the text of the law. In practice, however, enforcement is at best weak, and many workers end up not being covered by mandatory regulations. Such workers are often referred to as informal workers. Given the difficulties in measuring the extent of informality, different approaches have been followed in the literature. Some authors follow the traditional ILO approach of classifying as informal those workers who are either self-employed, work for firms with five or less employees, work as unpaid family help or are employed as domestic workers. Although some of these workers may be receiving the benefits prescribed by the law, there tends to be a high correlation between being in any of these categories of employment and not being covered by labor laws. Other authors use a more direct measure of informality, computing the 
percentage of workers who are affiliated with social security programs or have a formal labor contract. All authors in this volume use a "benefits" definition of informality except for the study by Maloney and Nuñez-Mendez, which follows the ILO convention.

Measured by the extent of compliance with social security regulations in Latin America, non-compliance is substantial. According to IADB (2003), only 39 percent of all workers and 60 percent of all wage employees are contributing to such programs (See Table 2). Among the countries covered in the individual studies of this volume, compliance as percentage of total employment is the highest in Chile and Uruguay and the lowest in Peru. Compliance tends to be higher among skilled workers, among workers employed in larger firms and in the manufacturing and high-paying finance and business services sectors. In these latter sectors, the effect of regulations should be easier to detect. Compliance is higher when the burden of regulation is lower.

\section{The Impact of Labor Market Regulations}

This section summarizes the studies of the impact of labor market regulations that are presented in this volume and places them in the context of the literature on more economically developed countries. We distinguish between policies that alter employment levels (generating static costs) from policies that affect employment flows (generating dynamic transition costs). The essays contained in this book present evidence on both types of policies. We also report findings on the effects of temporary contracts and minimum wages.

\subsection{A Static Labor Demand-Labor Supply Analysis}


A convenient starting point from which to assess the impact of labor market regulations on employment levels the standard neoclassical labor demand-labor supply framework. If mandatory legislation increases labor costs, economic theory predicts that a move up the labor demand function produces a fall in employment. The slope of the labor demand schedule provides a good measure of the policy-induced change in employment when governments or trade unions set labor costs administratively. The standard theory is silent about the effects of the regulation on unemployment because it depends on whether the displaced workers drop out of the labor force or attempt to seek new jobs.

Table 4 summarizes estimates of constant-output labor demand elasticities for Latin America. As noted by Hamermesh (this volume), these estimates are comparable to those estimated for other countries. ${ }^{17}$ Although labor demand studies abound, we focus on those studies that use disaggregated industry or individual firm data to infer the labor demand parameters, since models fit on such data produces more reliable estimates of underlying production parameters than models fit on data at higher levels of aggregation (Hamermesh, 1993). Comparisons across types of workers indicate that labor demand elasticities are larger for blue-collar than for white-collar workers, suggesting a lower impact of regulations on the employment rates of the latter. Estimates of labor demand for Latin America tend to be somewhat lower than those obtained for other countries of the world, especially those estimated for Peru and Mexico. (See the estimates from industrial countries in the lower panel of the table.) Nonetheless, all estimates are between 0 and 1.5 , and most of them cluster between -0.2 and -0.6 , well within the range for worldwide

\footnotetext{
${ }^{17}$ A more comprehensive measure of the impact of regulations on employment is given by the total elasticity, that includes the possible scale effects of an increase in regulation including the entry and exit of firms due to changes in labor costs. Unfortunately, there is very little empirical evidence in this book regarding the magnitude of the total elasticity although studies by Hopenhayn and Rogerson (1993) and Nicoletti and Scarpetta (2003) suggest that entry and exit decisions are an important component of the response to regulation.
} 
estimates reported by Hamermesh (1993) for output- constant labor demand elasticities. ${ }^{18}$ This range of estimates implies that a 10 percent increase in labor costs will result in a sizable decline in employment, between 2 percent and 6 percent.

The preceding analysis assumes that the cost of regulations is entirely paid by employers. However, when the supply of labor is not perfectly elastic, part of the increase in labor costs will be compensated by lower wages, reducing the disemployment effect of the regulations. Alternatively, workers may not perceive the cost of regulation as a tax, since higher contributions pay for improved job benefits, which are valued. In this case, workers will be willing to pay for this benefit, reducing their wage demands. This wage offset would also contribute to lessening the impact of regulations on employment.

How likely is it that the costs of labor market regulations are shifted to workers in Latin America? Before reviewing the existing evidence, it is important to note important features of Latin American labor markets. First, high evasion implies that the relevant labor supply to the formal sector in developing countries is likely to be more elastic than in developed ones. Thus, if workers have access to similar jobs in both the formal and informal sectors, the possibilities of shifting costs to workers are lessened, resulting in a high elasticity of labor supply to formal sector firms that comply with regulations. Second, as previously noted, in some countries minimum wages are quite high, both absolutely and in relation to the average wage and this reduces the scope for wage shifts (see Figure 2). Moreover, Maloney and Nuñez-Mendez (this volume) show piling up of workers at minimum wage levels, suggests that compliance with the minimum wage is substantial even in the so called "informal" sectors so that wage shifting will be attenuated in countries with a binding minimum wage that also affects the informal sector. Third,

\footnotetext{
${ }^{18}$ Hamermesh reports a range between -0.15 and -0.75 and an average estimate of -0.45 .
} 
although most social security programs in the region are restricted to covered workers, and this tightens the link between contributions and benefits, the dismal financial condition of some social security systems and the high degree of discretion exercised by governments over the determination of benefits weaken this link. In this respect, the recent social security reforms aimed at privatizing pensions should strengthen the relationship between benefits and costs in many countries of the region.

Several empirical studies have attempted to measure the impact of mandatory benefits on employment rates. Gruber (1994) analyzes the effects of insurance for workplace injuries and mandated maternity benefits in the U.S. and finds that a large share of the cost is shifted to wages with only minor disemployment effects. In contrast, Kaestner (1996) examines the effect of unemployment insurance contributions on the employment of U.S. youth and finds large disemployment effects and little wage shifting. For developing countries, there is some evidence on the magnitude of wage shifts predating the studies collected in this volume. MacIsaac and Rama (1997) assess the fungibility of the cost of mandated benefits in Ecuador. In 1994, the year they study, Ecuador had one of the most cumbersome labor legislation regimes in Latin America. Beyond mandated contributions to social security programs, the law also mandated payment of thirteen, fourteen, fifteen and sixteen-month payments for separation at various times of the same year. MacIsaac and Rama's analysis suggests that while labor market regulations increase labor costs, part of the increase is shifted to workers in the form of lower base wages. Thus, for an average Ecuadorian worker, social security contributions and other mandated benefits amount to at least 57 percent of the base wage. However, workers whose employers comply with regulations earn on average only 18 percent more than workers at non-compliant firms. This difference is explained by a 39 percent 
reduction in the base earnings of workers in compliant firms. Interestingly, these reductions are not uniform across firms; they are smaller in larger firms and essentially zero in the public sector and in unionized firms.

Mondino and Montoya (this volume) and Edwards and Cox-Edwards (1999) explore this topic for Argentina and Chile, respectively, by comparing wages of workers who have access to social security programs with wages of uncovered workers. In Argentina, Mondino and Montoya (this volume) find that during the period 1975-1996, wages of non-covered workers were 8 percent higher than the gross wages of covered workers. Considering that employee-paid payroll contributions average 40 percent of the payroll, the share of contributions paid by workers is around 20 percent of total labor costs. In Chile, Edwards and Cox-Edwards find evidence of a larger wage shift. In 1994, cash wages for workers covered by mandatory pension, health, and life insurance were 14 percent lower than wages for non-covered workers. Since in that year, social security contributions amounted to 20 percent of wages and were nominally paid by workers, their estimates suggest that about 70 percent of the cost of social security contributions were absorbed by workers, while the other 30 percent fell on employers. Gruber (1997) reports evidence of an even larger wage shift in the aftermath of the 1981 pension reform in Chile. The 1981 reform reduced employer-paid labor taxes and increased taxes paid by employees. In addition, the funding of some programs was shifted to general revenue. Using this tax change as a "natural experiment" and data on individual firms" payments in labor taxes and wages, he seeks to determine whether lower employer-paid labor taxes are 
associated with higher wages within a firm. His results suggest a full-shift of payroll taxes to wages and no effect on employment. ${ }^{19}$

Marrufo (2001) examines the 1997 reform in Mexico, which, as in Chile, transformed the pay-as-you-go pension system into an individual retirement accounts (IRA) system. She finds evidence of substantial employment reallocation between noncovered and covered sectors suggesting that the labor supply to covered sectors is fairly elastic. However, she also finds evidence of a wage shift in response to a reform that ties benefits to taxes collected. Decomposing the effect of the reforms into the effect of a tax reduction and the effect of tying benefits to contributions, she finds that increasing social security taxes reduces wages by 43 percent of the tax increase, while increasing benefits decreases wages by 57 percent of the value of benefits.

An important factor determining the extent of wage pass-through is whether minimum wages bind. Maloney and Nuñez-Mendez (this volume) document that the minimum wage binds in Colombia. This explains the weak pass-through effects reported by Cardenas and Bernal (this volume) for Colombia. At the same time, the minimum wage is less binding, and pass-through effects may be more substantial, in Mexico and Chile, and this may explain the Marrufo and Gruber results.

All in all, the available evidence suggests that at least part of the cost of non-wage benefits is passed on to workers in the form of lower wages, and therefore, the employment

\footnotetext{
${ }^{19}$ Measuring the impact of such an "experiment" is complicated by many factors. (See the discussion in Edwards and Cox-Edwards, 2000). First, although payroll taxes declined, worker contributions increased. If measured wage payments by firms include employee contributions, then a decline in employer-paid taxes will be associated with higher measured wages due to higher employee-paid contributions. Second, measurement error in wages biases his estimates toward finding full shifting, as he reports. The quality of his instruments is questionable and he is forced to make strong assumptions to circumvent a severe measurement error problem. Third, at a time when social security reform made work benefits more attractive, he estimates that wages were rising. The only way that wages can rise to match the decreased employer taxes in an environment with an improved link between employee contributions and benefits is if labor supply is perfectly inelastic to covered sector firms, which seems implausible.
} 
cost of such programs will be lower than what is predicted by the elasticity of the labor demand. Combining wage-shift and labor demand estimates indicates that a 10 percent increase in non-wage labor costs can lead to a decline in employment rates ranging between .6 and 4.8 percent with most of the evidence shaded toward the high end of this spectrum.

Given the significance of these estimates for policy decisions, it is important to estimate them as accurately as possible. In this regard, the room for improvement in the literature is still large. As they stand, they might overestimate or underestimate the true employment impact depending on which of the following two effects dominates. On the one hand, the reported estimates are based on constant-output labor demand elasticities, which do not consider the employment effects of regulations through a negative effect on the scale of production of existing firms and on entry and exit decisions of firms. From this perspective, the reported range of estimates provides a lower bound on the disemployment effects of regulation. Moreover, the estimates of the wage shift in MacIsaac and Rama (1997), Mondino and Montoya (this volume) and Edwards and Cox-Edwards (1999) only include the cost of social security programs, but do not include the cost of other regulations such as job security or vacation time. Once the cost of these regulations is taken into account, the computed wage shift could be lower than what we report above, and, therefore, the estimated effects of those costs on employment would be larger.

On the other hand, studies comparing wages of covered and non-covered workers performed using a cross-section of workers, such as most of the ones discussed above, may underestimate wage shifts and overestimate employment costs. It is necessary to model selection into covered sectors. This is because unobserved personal characteristics 
correlated with social security affiliation might explain higher wages in covered sectors. ${ }^{20}$ If this correlation is substantial, it will lead to an underestimation of wage differences between covered and uncovered workers, and hence reduce estimates of the fraction of wage costs shifted to workers. This concern highlights the importance of the Marrufo study because she controls for sectoral self-selection bias and still finds substantial evidence of wage shifting. If her selection adjustments to the Mexican data are typical of what would be found in other Latin American countries, the weight of the evidence in this book and the literature on firm entry in response to incentives, suggest that the studies reported in this volume underestimate the disemployment effects of regulation.

\subsection{Job Security Provisions Alter Hiring and Firing Decisions}

Regulations affecting transition costs are not adequately analyzed within a simple static labor-demand labor-supply framework. Dismissal costs and other regulations not only increase labor costs, but also alter firms' firing and hiring decisions. The importance of dismissal costs in Latin America is clearly shown in Figure 5. Whereas non-wage labor costs are low relative to those of OECD countries, dismissal costs tend to be very high. These costs make Latin American labor markets less flexible than OECD markets and likely impair productivity and adaptation to new technology and trade patterns as they do in Europe (see Heckman, 2003). It is thus important to assess the impact, if any, that such policies have on the functioning of the labor market.

\section{Theoretical Discussion}

\footnotetext{
${ }^{20}$ For instance, if workers covered by social security programs also happen to be more productive, then they will also have higher wages. Yet, higher wages are explained by unobserved productivity and not by social security affiliation.
} 
To analyze the full impact of job security provisions requires a more complex framework that encompasses dynamic decisions of firms. Bertola (1990) and Bentolila and Bertola (1990) develop dynamic partial-equilibrium models to assess how a firm's firing and hiring decisions are affected by dismissal costs. In the face of a given shock, the optimal employment policy of a firm involves one of three state-contingent responses: (i) dismissing workers, (ii) hiring workers or (iii) doing nothing. Appendix B presents a simple two period model of labor adjustment that summarizes the main ideas in this literature.

In the face of a negative shock and declining marginal value of labor, a firm might want to dismiss some workers. However, it faces a dismissal cost in most regulatory regimes in LAC. This cost has the effect of discouraging firms from adjusting their labor force, resulting in fewer dismissals than the number of dismissals that would occur in a scenario in the absence of such costs. Conversely, in the face of a positive shock, firms might want to hire additional workers but would take into account that it would be costly for some workers to be fired if future demand declined. This potential cost acts as a hiring cost, effectively reducing the creation of new jobs in a relatively healthy economy. The net result is lower employment rates in expansions, higher employment rates in recessions and lower turnover rates as firms hire and fire fewer workers than they would in the absence of adjustment costs.

Adjustment costs produce a decline in employment variability associated with firing costs. The implication of these models for average employment is ambiguous. In particular, whether average employment rates increase or decline as a result of firing costs depends on whether over the cycle the decline in hiring rates more than compensates for the reduction in dismissals. Simulations reported in Bertola (1990) and Bentolila and 
Bertola (1990) suggest that average employment in a given firm is likely to increase when firing costs increase. However, these results are quite sensitive to different assumptions about the persistence of shocks, the elasticity of the labor demand, the magnitude of the discount rate, and the functional form of the production function. Less persistent shocks and lower discount rates produce larger negative effects of job security on employment because both factors reduce hiring relative to firing (Bertola, 1992; Bentolila and Saint Paul, 1994). Furthermore, a higher elasticity of the demand for goods implies a larger negative effect of job security on employment rates. In addition, when investment decisions are also considered, firing costs lower profits and discourage investment, increasing the likelihood that they reduce the demand for labor (Risager and Sorensen, 1997).

The Bertola (1990) and Bertola and Bentolila (1990) analyses focus on employment rates in a "representative" firm without considering the impact of firing costs on the extensive margin, that is, on how firing costs affect the creation and destruction of firms. Hopenhayn and Rogerson (1993) develop a general equilibrium model based on the U.S. economy. The partial equilibrium framework of Bertola (1990) is embedded in their model as part of a general equilibrium framework in which jobs and firms are created and destroyed in every period in response to firm-specific shocks. In the context of their model, Hopenhayn and Rogerson find that increasing firing costs in the U.S. would lead to an increase in the average employment of existing firms as a consequence of the reduction in firings. However, they also find that such a policy would result in lower firm entry, and lower job creation in newly created firms. These final two effects could potentially offset the increase in employment in existing firms, and they would thus reduce overall employment rates. 
The recent literature has also emphasized the possible impact of job security regulations on the composition of employment. Kugler (this volume) proposes a model in which job security regulations provide incentives for high turnover firms to operate in the informal sector. This decision would entail producing at a small, less efficient scale in order to remain inconspicuous to tax and labor authorities. In this framework, high job security costs paid by formal sector firms would likely increase informality rates. Pagés and Montenegro (1999) develop a model in which job security provisions, which depend on tenure, bias employment against young workers and in favor of older ones. As severance pay increases with tenure, and tenure tends to increase with age, older workers become more costly to dismiss than younger ones. If wages do not adjust appropriately, negative shocks result in a disproportionate share of layoffs among young workers. Therefore, job security based on tenure results in lower employment rates for the young relative to older workers because it reduces hiring and increases layoffs for young workers. This effect has also been found in studies of European employment. (Heckman, 2003).

Finally, it is important to understand that not all components of dismissal costs may have the same effect on employment and unemployment rates. Thus, in principle, there is an important conceptual distinction between advance notice and indemnities, which are state-contingent and affect the cost of adjustment to different states, and seniority pay provisions, which are paid in all states and do not affect transitions. The latter are more comparable to other non-wage costs such as vacation and other mandatory benefits.

The existing evidence regarding the impact of employment protection is abundant but inconclusive. Table 5 from Addison and Teixeira (2001) summarizes the current literature. While, Addison and Grosso (1996), Grubb and Wells (1993), Lazear (1990), Heckman and Pagés (2000), Nickell (1997) and Nicoletti and Scarpetta (2001) find a 
negative relationship between job security provisions and employment, other studies, such as Addison, Teixeira and Grosso (2000), OECD, (1999), Garibaldi and Mauro (1999) and Freeman (2001) do not find evidence of such a relationship. The evidence on the effects of job security on unemployment is equally ambiguous. Some studies find a positive link between job security and unemployment (Elmeskov, et al., 1998; Lazear, 1990; and Addison and Grosso, 1996) while others find no effect (Blanchard, 1998; Heckman and Pagés, 2000; Nickell, 1997). Our own estimates at the end of this chapter give reasons for these mixed findings. All these studies are based on the analysis of aggregates of crosscountry time-series data with little variation in regulatory policies. The studies presented in this volume surmount some of these difficulties by studying episodes of major labor reform using large micro data sets. Using disaggregated data for single countries, Mondino and Montoya (this volume) and Saavedra and Torero (this volume) find a large negative relationship between employment protection and employment. The studies presented in this volume contribute substantially to a literature that analyzes the consequences of reforms. Recent studies for OECD countries using disaggregated data suggest a negative effect of job security regulations on employment. Autor et al. (2003) estimate the effects of recent common law wrongful discharge doctrines adopted by courts across states in the U.S that limit employment at will. They find that the wrongful discharge doctrine has a negative impact on employment to population rates in state labor markets. Similarly, Kugler et al (2002) find that in Spain a combination of a reduction in payroll taxes and the reduction of dismissal costs increased the employment of workers on permanent contracts. Finally, Acemoglu and Angrist (2001), replicating the earlier work of Deleire (2000), examine the effects of the Americans with Disabilities Act (ADA), which outlaws discrimination against the disabled in hiring, firing and pay on the employment 
rate of workers with disabilities. Their findings and prior work by Deleire suggest that the passage of the Act reduced employment for disabled workers.

\section{Empirical Evidence for Latin America and the Caribbean}

The essays assembled in this volume assess the impact of job security regulation on employment and turnover rates in Latin America and the Caribbean, and provide the first systematic evidence of its impact on the labor market. Several studies assess the impact of job security on turnover rates in the labor market. Changes in turnover are measured using changes in the duration of jobs (tenure), the duration of unemployment and rates of exiting out of employment and unemployment. ${ }^{21}$ Higher employment exit rates indicate more layoffs (or more quits), while higher exit rates out of unemployment and into formal jobs indicate higher job creation in the formal sector. Other studies examine the impact of job security on employment rates. The definition of employment used in the empirical studies varies depending on the country being analyzed. In general, most studies focus on employment in large firms, although some also examine more aggregated measures of employment. In addition, a small group of studies also examine the impact of job security on the composition of employment. See Table 6 for an overview of the empirical evidence for Latin America and the Caribbean presented in this volume.

\section{Turnover Rates}

As predicted by most theoretical models, the bulk of empirical evidence reported in this volume confirms that less stringent job security tends to be associated with higher

\footnotetext{
${ }^{21}$ These studies estimate hazard rates. The hazard rate is defined as the rate at which a given spell of employment or unemployment ends in a given period conditional on having lasted a given period of time in the spell (e.g., one month, one year).
} 
turnover and greater flexibility in the labor market. Kugler (this volume) analyzes the impact of the 1990 labor market reforms in Colombia. She finds that a reduction in job security costs reduces average tenure and increases employment exit rates. ${ }^{22}$ This decline is significantly larger in the formal sector, which is covered by the regulations, than in the uncovered or informal sector. In addition, the increase is greater in large firms than in the smallest ones. Her results show similar patterns within tradable and non-tradable sectors, providing a clear indication that the decline in tenure cannot be attributed to contemporary trade reforms. The increasing use of temporary contracts explains only part of the increase in formal turnover rates since job stability also declined for workers employed at permanent jobs. $^{23}$

Kugler also finds a decline in the average duration of unemployment after the reforms. In addition, exit rates out of unemployment increase more for workers who leave unemployment by going into the formal sector than they do for those who exit into informal jobs. As with average tenure, her results show quite similar patterns across sectors and a higher exit rate toward larger firms. Finally, only two-thirds of the increase in the rate of entry into unemployment can be attributed to higher use of temporary contracts. The rest is explained by increased exit rates into permanent jobs in the formal sector. Saavedra and Torero (this volume) conduct a similar study, evaluating the impact of the 1991 reform in Peru. Like the reform in Colombia, the 1991 Peruvian reform considerably reduced the cost of dismissing workers. Their analysis shows a consistent decline in average tenure from 1991 onward, suggesting higher exit rates from

\footnotetext{
${ }^{22}$ In this study tenure is measured by the duration of incomplete employment spells.

${ }^{23}$ In her study, Kugler performs two types of analyses. First, she uses a difference-in-difference estimator to analyze whether changes in average duration of employment (unemployment) are significantly different in the formal and informal sectors. Second, she estimates an exponential duration model to control for changes in demographic covariates, pooling data from before and after the reform and using interaction terms to assess the differential impact on the formal and informal sectors.
} 
employment. As in the Kugler study, the decline is significantly more pronounced in the formal sector than it is in the informal sector. In addition, the tenure patterns were quite similar across economic sectors, suggesting that these findings cannot be explained by the trade reforms that took place in the early nineties.

In contrast to these findings, Paes de Barros and Corseuil (this volume) find little evidence that the substantial 1988 Brazilian Constitutional reform altered employment exit rates. In that year, the cost of dismissing workers was raised, and therefore a reduction in exit rates would be expected as a result. (Many other reforms were also put in place as well.) Their results indicate that aggregate employment exit rates decline in the formal sector relative to the informal sector for short employment spells (two years or less), but increase for longer spells. Their measured increase in exit rates for long spells could be driven by the special characteristics of the Brazilian system. In this system, employers contribute 8 percent of a worker's wage to the worker's individual account. In case of voluntary dismissal, the worker can claim the principal, the compounded interest rate and a penalty paid by the firm, which in the 1988 reform was raised from 10 percent to 40 percent of principal plus interest. In the case of a voluntary quit, the worker receives nothing. This asymmetry in the treatment of termination induces workers to force dismissal or to collude with firms to obtain the funds accumulated in the account. It can be argued that the 1988 reform greatly increased the incentives to force dismissals, particularly for workers with longer tenures. This may explain the increase in exit rates for workers with longer employment spells.

These three studies use the informal sector as a control group unaffected by the reforms. Their credibility hinges on the validity of this assumption. Kugler shows that estimates based on formal-informal sector comparisons are likely to be biased. However, 
such comparisons are still valid under certain conditions - at least as tests of the null hypothesis of no effect of the reform. ${ }^{24}$ When viewed as a whole, these studies provide evidence that dismissal costs and other employment protection mechanisms reduce worker reallocation in the labor market. Unfortunately, these studies do not identify whether reduced worker reallocation is due to reduced layoffs, lower quits or a mix of both.

Some studies in this book assess the impact of regulations on the speed of adjustment using the length of the lag (the speed of adjustment) as an alternative measure of the constraints faced by firms. The intuition supporting this is based on the original work of Holt, Modigliani, Muth and Simon (1960).

Let $n_{t}^{*}$ be the optimal level of employment at date $t$ determined by some implicit (usually static) theory. Let the cost of being out of equilibrium $c_{t}^{0}$ be quadratic in deviations of current employment from optimal employment:

$$
c_{t}^{0}=\gamma_{0}\left(n_{t}^{*}-n_{t}\right)^{2} \quad \gamma_{0}>0 .
$$

The greater the discrepancy between employment at $t$ and optimal employment, the greater the cost. There is also a cost of adjustment $c_{t}^{a}$, which is also assumed to be quadratic in the adjustment from $n_{t-1}$ to $n_{t}$ :

$$
c_{t}^{a}=\gamma_{a}\left(n_{t}-n_{t-1}\right)^{2} .
$$

Minimizing the sum of these costs produces an optimal labor demand $n_{t}$

\footnotetext{
${ }^{24}$ Kugler shows that lower severance pay may induce high-turnover informal firms to move to the formal sector. Assuming either no overlap in the distribution of turnover between covered and uncovered firms, or that entry to the covered sector comes from the high-end -or at least from the end that is higher than the formal sector, this shift results in higher turnover in both the formal and the informal sector. Higher turnover in the informal sector biases the difference-in-difference estimator downward. Therefore, a positive estimate still provides substantial evidence of increased turnover in the formal sector.
} 


$$
n_{t}=(1-\lambda) n_{t}^{*}+\lambda n_{t-1}
$$

where

$$
\lambda=\frac{\gamma_{a}}{\gamma_{a}+\gamma_{0}} .
$$

The greater the cost of adjustment, the bigger the value of $\lambda$. Abraham and Houseman (1993) and many others use this method to assess the effect of different regulatory regimes across countries on adjustment costs while others interact $\lambda$ with measures of regulations to assess whether the speed of adjustment increases or declines when the regulatory environment is changed. Cardenas and Bernal (this volume), Paes de Barros and Corseuil (this volume) and Saavedra and Torero (this volume) use this methodology to examine whether the speed of adjustment increased or declined after labor reforms. In the study of Saavedra and Torero, their estimated interaction term suggests that more stringent regulations reduce the speed of adjustment, particularly in the pre-reform period, when regulation was very stringent. In the other two studies, this methodology is unable to identify any changes in adjustment due to reforms. This is particularly relevant in the study of Cárdenas and Bernal on Colombia since other methodologies based on duration data (Kugler, this volume) show clear effects of regulation on adjustment. Addison and Teixeira (2001) indicate that "none of the implementations of this (adjustment cost) model in core OECD countries were able to detect a discernible impact of job security regulations on the speed of employment adjustment". In the concluding section of this paper, we discuss why the lag coefficient is not a reliable measure of the regulatory costs, especially when applied to cross country data.

\section{Average Employment}


The available evidence for LAC countries shows a consistent, although not always statistically significant, negative impact of JS provisions on average employment rates. Saavedra and Torero (this volume) and Mondino and Montoya (this volume) use firm-level panel data to estimate the impact of job security on employment in Peru and Argentina, respectively. Both studies estimate labor demand equations in which an explicit measure of job security appears on the right hand side of the equation, and both find evidence that higher job security levels are associated with lower employment rates. ${ }^{25}$ In the case of Peru, Saavedra and Torero find that the size of the impact of regulations is correlated with the magnitude of the regulations themselves. Thus, the impact is very high at the beginning of their sample (1987-1990), coinciding with a period of very high dismissal costs (see their Table 4). Afterward, and coinciding with a period of deregulation, the magnitude of the estimated coefficient declines after a new increase in dismissal costs, only to increase again from 1995 onward. Their estimates for the long-run elasticities of severance pay are very large (in absolute value). Between 1987 and 1990 a 10 percent increase in dismissal costs is estimated to reduce long-run employment rates by 11 percent, keeping wages constant. In subsequent periods, the size of the effect becomes smaller but is still quite large in magnitude (between 3 and 6 percent). In Argentina, the estimated long-run elasticity of a 10 percent increase in dismissal costs is also between 3 and 6 percent. ${ }^{26}$

\footnotetext{
${ }^{25}$ The data for the Peruvian study covers firms with more than 10 employees in all sectors of the economy. The Argentinean study only covers manufacturing firms. Given the nature of these surveys, these studies analyze formal employment rather than employment as a whole. The data used in these two studies does not capture job creation by new firms, since both panels are based on a given balanced panel census of firms, which does not adjust for attrition.

${ }^{26}$ The methodology used by these studies might lead to upward biased estimates of the elasticity of employment to job security. Thus, for example, Mondino and Montoya construct explicit measures of job security based on:

$$
J S_{j t}=\delta_{j} T_{j t} P_{j t} S P_{j t}
$$

Where $\delta_{j}$ is the average layoff rate in sector $j, T_{j t}$ is average tenure in sector $j$, for a time period $t, P_{j t}$ is the share of firms in sector $j$, time period $t$ that are covered by regulations and $S P_{j t}$ is the mandatory severance pay in sector $j$, given average tenure $T_{j t}$. This measure provides variability across sectors and periods, and therefore it yields a more precise estimation of the impact of job security than before-after types of
} 
Kugler (this volume) computes the net impact of the Colombian 1991 labor reform on unemployment rates. Using unemployment and employment exit rate estimates before and after the reform, she finds that the reforms cause a decline in unemployment between 1.3 and 1.7 percentage points. Thus, as in Mondino and Montoya (this volume) and Saavedra and Torero (this volume), Kugler's estimates of the impact of deregulation indicate that the positive impact of reduced labor costs on hiring outweighs the negative impact of reduced severance costs on firing, resulting in a decline in unemployment rates.

Heckman and Pagés' (2000) analysis of cross section-time series aggregates also finds evidence of a negative impact of employment protection on employment. However, the evidence presented at the end of this chapter suggests that their results for Latin America are not robust although their results for OECD Europe are robust. The fragility of their estimates for Latin America based on aggregate data suggests the value of using more disaggregated data in reaching sharp conclusions.

Other studies find negative, but statistically less precisely estimated, effects of job security on average employment rates. Pagés and Montenegro (1999) find that $J S$ has a negative but statistically insignificant effect on overall wage-employment rates in Chile. Similarly, Marquez (1998), using a cross-section sample of Latin American and OECD countries, finds a negative but insignificant coefficient of job security on aggregate employment rates. Table 6 summarizes the various estimates of job security on employment.

Downes et al (this volume) also use aggregate time series data to examine changes in the labor demand associated with changes in the regulatory framework in three

comparisons. Yet, such a measure may also be correlated with the error term in a labor demand equation since both layoffs and the tenure structure of a firm might be correlated with its employment level. However, 
Caribbean countries. Their inconclusive results are typical of an entire literature. They use an indicator variable that measures periods with more or less stringent regulations. Their estimates do not capture changes in labor demand before and after the reform. However, as in the case in most of the OECD-based literature, their sample variation in regulations and institutions may be too limited and the level of aggregation too great to capture any effects of regulation on employment.

\section{The Composition of Employment}

Economists have paid relatively more attention to studying the effects of job security on the level of employment and unemployment than to studying the effects of such policies on the distribution of jobs. However, a few studies shed some light on the impact of job security on the composition of employment in LAC. Marquez (1998) constructs a ranking of the relative severity of labor market regulations (including workweek, contract and other regulations besides job security provisions) for LAC and OECD countries and uses it to estimate the effects of JS on the formal/informal distribution of employment. He finds that across countries more stringent regulations coincide with a larger percentage of self-employed workers. In a study of Chile, Montenegro and Pagés (this volume) use repeated cross-section micro-data spanning forty years of data and substantial variation in labor market policies. They control for year effects that are common across workers, as well as for the differential effects of the business cycle, and other labor market policies on each demographic group. They find that more stringent job security measures reduce the employment rates of youth and the unskilled, while increasing the employment rates of older and skilled workers. Their 
results also suggest that job security regulations increase the self employment of women and unskilled workers, relative to other demographic groups. This evidence is consistent with evidence in Bertola (2001) and Heckman (2003) that job security provisions protect the relatively privileged workers at the expense of the less advantaged ones. In a review of the recent OECD literature, relying on cross-country, time-series analysis, Addison and Teixeira (2001) reach similar conclusions stating that while prime-age male employment rates have not been affected by job security provisions, the employment rates of other groups, most notably younger workers, have been affected.

\subsection{Temporary Contracts}

Hopenhayn (this volume) discusses the impact of temporary contracts on the Argentine labor market. Such contracts were introduced following the Spanish model. $\mathrm{He}$ finds that these contracts induce an increase in hiring and a substitution away from longterm employment toward short-term employment. So, in the short-run, these contracts remove one barrier from the labor market and make it more fluid. At the same time, they tend to promote turnover. Hopenhayn finds that the average hazard rate for the first three months out of employment increased by 30 percent and for tenure above three months by 10 percent. While temporary contracts promote fluidity, they reduce firm attachment and the incentive of firms to invest in workers. Alonso-Borrego and Aguirregabiria (1999) document that in Spanish labor markets, the effect of temporary contracts is to reduce investment in workers and hence to produce lower quality (less skilled) workers in the long run.

still produces positive and statistically significant estimates for the coefficient of the job security measure. 


\subsection{Minimum Wages}

Maloney and Nuñez-Mendez (this volume) present novel estimates of the impact of minimum wages on wage distributions and employment. Their evidence demonstrates convincingly that minimum wages are binding in most Latin American countries and have substantial effects on employment and wage distributions. An important finding in their analysis is that both covered and uncovered sectors ("formal" and "informal" sectors) respond in similar fashion to wage minimums. The informal sector does not show the downward wage flexibility that traditional models of labor market dualism predict. Another important finding is that minimum wages percolate much more widely across wage distributions in Latin America than they do in the U.S. There are substantial effects of minimum wages on wages far up in the distribution of wages. Their study puts to rest the claim that minimum wages are innocuous, even in countries with large "informal" sectors.

Montenegro and Pagés (this volume) study the effects of minimum wages on the distribution of employment in Chile. They find that, like job security provisions, minimum wages reduce the employment probabilities of the young and the unskilled relative to older and more skilled workers. Not surprisingly, as suggested in other studies for developed countries, their results indicate that minimum wages are particularly binding for young unskilled workers. However, their results also indicate an adverse effect of the minimum wage on prime-age unskilled workers. Minimum wages adversely affect disadvantaged workers of all ages.

We next turn to a pooled time series cross-country study of the impact of regulation on employment. The fragility and sensitivity of the estimates for the Latin American region that we find highlight the benefits of the microdata analysis reported in this volume. 


\section{Evidence from A Cross-Section Time-Series Sample of LAC and OECD Countries}

In this section, we summarize and expand on some of the main results of our recent work, updating our earlier paper (Heckman and Pages, 2000). We use time series of crosssections of countries and we exploit the substantial variability in labor laws in Latin America to estimate their effects on employment and unemployment. These studies serve to place the essays in this volume within the broader context of a literature that almost exclusively focuses on time series of cross section averages of countries. Unfortunately, few empirical regularities emerge when an honest sensitivity analysis is conducted. Nonetheless a few robust regularities do appear. Payroll taxes reduce employment and (less robustly) in OECD countries, job security regulation reduces employment.

\section{The Data}

Labor market studies focusing on developing countries are hampered by serious data problems. Thus, labor market variables contained in most cross-country databases suffer from a lack of comparability and reliability. To overcome these problems, we construct a new data set that includes OECD and LAC countries. For OECD countries, we collect employment and unemployment data from the OECD statistics. For the Latin American

sample, we directly construct the same indicators out of a large set of Latin American Household Surveys. See Appendix A for a more detailed description of the employment and unemployment variables as well as the countries and years used to obtain the LAC data. Population variables are obtained from the UN Population database while GDP measures are from the World Bank Development Indicators. To characterize labor market 
regulations we use the set of measures summarized in Table 4, but defined for each year and country.

Our joint sample collects more than 400 data points from 38 countries; 23 in the OECD and 15 in LA. (Mexico is included in the Latin America sample although it belongs to the OECD). We analyze country means and do not disaggregate further. The sample is an unbalanced panel covering the period 1983-1999. Table 7 reports summary statistics of our data for both our whole sample and for the sub-regional ones. There are large differences between the OECD and the LAC samples. GDP per capita measures tend to be substantially lower in the LAC than in the OECD region. Conversely, GDP growth is lower in the latter. Indemnities for dismissal and seniority pay are higher in Latin America than in OECD countries while advance notice provisions and social security contributions are lower. There are important differences in labor market aggregates as well. On average, employment rates are higher in the LAC region than in OECD countries. The reverse is true for unemployment rates. The LAC region also displays a lower percentage of the working age population in the 25 to 54 and the 55 to 65 years old brackets than OECD countries and a higher share of the population in the 15 to 24 years age group. By constructing our own data set from individual household-level surveys, we are guaranteed that all of the labor market variables are comparable and reliable. One drawback of our data is that for the LAC sample, we only have a few time series observations per country (usually six or seven), and not necessarily from consecutive years.

Our objective is to relate our measures of regulations to employment and unemployment outcomes. Although we perform multivariate analyses, it is interesting to examine the bivariate relationship between regulations and employment. This is particularly easy for regulations such as job security provisions that, within our sample, 
change at most once or twice per country. In figures 8 and 9, we graph employment before and after reforms for countries that experienced job security reforms. The graphs for LAC should be interpreted with caution because they have been interpolated from incomplete time series data.

There is little evidence that reforms that reduced job security increased employment rates in Colombia. There is also not much evidence that reforms that increased job security had a deleterious effect on employment in Brazil, Chile or Nicaragua. However, there is some evidence indicating that reforms that liberalized labor markets in Peru increased employment rates, while reforms that increased labor market rigidities reduced employment. For Germany, our data suggest that employment declined at a slower rate after a reform that increased job security, while in Spain and UK the opposite seems to be true after liberalization. These figures suggest that periods of less stringent job security regulations coincide with higher employment rates in some countries, while the reverse is also true in other countries. The data presented in these figures, however, fail to control for contemporaneous changes in economic activity or other factors that could be correlated with employment and labor reforms. In the next section, we perform an empirical analysis in an attempt to control for contemporaneous effects that may be correlated with reforms, employment and unemployment outcomes.

\section{Methodology and Results}

To relate labor market regulations to employment and unemployment outcomes, we estimate the following model:

$$
Y_{i t}=\alpha_{i}+\beta_{1} X_{i t}+\beta_{2} g_{i t}+\beta_{3} G D P P C_{i t}+\beta_{4} Z_{i t}+\varepsilon_{i t}
$$


where $Y_{i t}$ is a labor market variable (employment or unemployment) of country $i$ at period $t, \alpha_{i}$ denotes a country fixed effect, $X_{i t}$ denotes a vector of employment regulation variables, $g_{i t}$ and $G D P P C_{i t}$ denote GDP growth and (log of) GDP per capita, respectively, $Z_{i t}$ is a vector of demographic controls and $\varepsilon_{i t}$ is a mean zero error.

Given the nature of the data with incomplete gaps, we decided not to average observations from a given period to control for business cycle effects, as is often done in OECD studies. Instead, we control for the state of the business cycle in a given year using GDP growth ${ }^{27}$. Although a large part of our variation is cross-sectional, we use fixed effects estimates to control for unobserved variables that may be correlated with measures of regulation across countries. In addition, we control for demographic changes that may be correlated with employment and unemployment rates as well as regulatory variables that change over time. Finally, we use GDP per capita (adjusted by PPP) to control for differences in levels of country economic activity across years. ${ }^{28}$ We estimate a reduced form model to investigate whether periods of high non-wage labor costs stemming from advance notice, indemnities for dismissal, severance pay or social security contributions are associated with lower employment or higher unemployment rates. We thus estimate an average net effect of labor laws as they operate through intermediate variables, which we do not include in the regression. We do not estimate a theoretically more appropriate statecontingent labor demand specification because we lack the information on the firmspecific state of the product market confronting individual firms. Therefore, we only attempt to identify the effect of labor laws through their effect on expected (across labor

\footnotetext{
${ }^{27}$ GDP growth is obtained from the World Bank Development indicators. It turns out that deleting or including this variable has no important effect on our empirical conclusions. Deleting or including GDP per capita (PPP adjusted) does not alter our results, either.
} 
market states) labor cost. This is a severe limitation. However, what we offer is an improvement over the existing literature on cross-country time series that does not quantify labor costs. Appendix B discusses conceptually more appropriate specifications of labor demand functions.

Table 8A displays our estimates for employment in the overall and regional samples. In these and subsequent results, we compute standard errors that are robust to heteroscedasticity. Throughout this analysis, we extend social security data to yearly frequencies since this information is only available biannually. We do so either by interpolating or by inputting each missing data values with the value from the former year. The results of our empirical analysis are robust across methods. The results do not vary either when we consider only the original biennial data. However, in this case, the number of available observations drops substantially.

The coefficients on GDP growth have the expected positive signs and are statistically significant for the overall sample. The coefficients on the demographic variables are positive, suggesting that countries with larger percentages of their working age population above age 25 tend to have higher employment rates. However, none of the coefficients on the demographic variables are statistically significant at conventional levels. A higher GDP per capita tends to coincide with higher employment to population rates. However, this estimated effect is not precisely determined.

Our main interest is on measuring the effect of the labor market regulations. We find that once we expand our sample to include a larger number of OECD and LAC countries, the strong negative effect on employment of indemnities for dismissal reported

\footnotetext{
${ }^{28}$ We control for GDP growth and GDP per capita (PPP adjusted) because we have few data points per country and they are not necessarily contiguous, so we cannot use the simple averaging method employed in OECD studies to control for business cycle effects.
} 
for the pooled sample in Heckman and Pagés (2000) disappears. This is somewhat surprising because not only do we expand the set of countries and periods for which we can construct the measure, but we also revise some of the variables used in our previous analysis to more accurately model the laws. We still estimate a negative, statistically significant, coefficient for indemnities in the OECD specification and this is an important contribution to the European debate on the impact of regulations. This evidence suggests a significant lack of robustness of the estimated effect of regulations that we explore in detail.

With regard to the rest of the regulations, we find a positive although not statistically significant coefficient on advance notice cost both in the joint and in the subregional samples. Since seniority pay regulations only exist in Latin America, we cannot identify the impact of these regulations in the OECD sample. However, we find positive coefficients for this variable both in the LAC and in the pooled sample. Moreover, the coefficient in the joint sample is statistically significant at the 5 percent level. The estimated coefficient suggests that an increase in payments equivalent to one month's pay (in expected present value) increases employment rates by 1.12 percentage points. One might argue that the strong association between contributions and benefits associated with these types of schemes contributes to an expansion of labor supply increasing overall employment rates. However, the coefficients on advance notice and on indemnities are also positive. In contrast to these results, our estimates suggest a negative effect of social security contributions on employment both in the joint and the sub-regional samples. (Recall this is the total contribution of employers and workers). This effect is statistically significant. According to our estimates, a reduction in the social security contributions from the OECD to the LAC average (see Table 4) would increase employment by 3.25 
percentage points for the coefficients from the joint sample or by 4.26 points if the OECD coefficient is used (table 8a, columns (1) and (6), respectively).

Since there is substantial correlation among our measures of labor market regulation, we also estimate specifications that include these measures one at a time. ${ }^{29}$ The number of observations used in each regression varies because there are countries for which we do not have information for all the regulation measures. The results are unchanged if we restrict all regressions to have the same observations than the ones used in column (1). Adding the regulation measures separately tends to produce smaller coefficients for each of them, suggesting that there are important complementarities that are not captured by the one-at-a-time specifications. We strongly reject the hypothesis that the four measures are not jointly significant (last row, Table 8A) and therefore include them together in the remaining analysis.

Table $8 \mathrm{~B}$ presents the estimates for unemployment. As for employment, indemnities for dismissal have a strong positive effect on unemployment in the OECD sample but no effect in the Latin America or the joint sample. The coefficient on advance notice is negative in the overall and OECD samples, but not in the LAC sample. However the coefficient is not statistically significant in any sample. The coefficient on seniority pay is also positive, suggesting that these schemes increase labor supply. However, the coefficient is not statistically significant. Finally, and consistent with our results on employment, we find that higher social security contributions are associated with higher levels of unemployment in the three samples considered. Our point estimates suggest that reducing social security contributions from the OECD to the LAC average reduces

\footnotetext{
${ }^{29}$ The correlation coefficient between advance notice, indemnities for dismissal and seniority pay is between .15 and .21 (in absolute value) and statistically significant. Social security contributions are positively and
} 
unemployment by 2.54 percentage points if we use the estimate for the joint sample or 3.11 points if we use the OECD one. As with the case of employment, adding the regulatory measures one-at-a-time produces smaller coefficients for each of the measures. As before, we reject the hypothesis that the coefficients of the four variables are jointly equal to zero, and therefore we will include them in the rest of the unemployment analysis.

Our results in Tables $8 \mathrm{~A}-8 \mathrm{~B}$ suggest that not all regulations have the same effect on employment and unemployment rates. Since all regulations are measured in multiples of monthly wages we can compare the coefficients of the four regulations studied and assess whether they have similar effects. In Table 9 we report the results of testing the hypothesis of equality of coefficients. We reject the null hypothesis of identical coefficients for the four measures in the employment, but not the unemployment, specifications. Interestingly, we are also able to reject the hypothesis that social security payments exert the same effect on employment as seniority pay, despite the fact that both variables imply mandatory contributions defined as fraction of wages. Perhaps because contributions to finance seniority pay are capitalized in individual accounts, the link between contributions and payments is strengthened, and this reduces or eliminates the "tax" effect. Instead, our results suggest that social security contributions tend to be perceived as taxes on labor and therefore reduce the demand of labor above and beyond a possible reduction in the supply of labor. Moreover, we reject the hypothesis that indemnities for dismissal and seniority pay have the same coefficient or that all components of job security (advance notice, indemnities for dismissal and seniority pay) have the same coefficient. When we impose this (incorrect) constraint on the data, we obtain a positive and statistically significant

significantly correlated with advance notice, but the correlation with the other measures is close to zero and not statistically significant. 
coefficient, while the coefficient on social security regulations remains negative and statistically significant.

Finally, although we reject the hypothesis that all four regulations have the same effect on employment, imposing this constraint yields a negative, statistically significant coefficient on employment and a positive, statistically significant coefficient on unemployment. Moreover, the size of the coefficients is very similar to the ones reported in Table 8.A and 8.B for social security. This is not surprising, since social security regulations constitute the lion's share of the total cost of regulations.

In summary, our results suggest that not all regulations have the same effect on employment rates. Thus, while social security contributions are negatively associated with employment (and positively associated with unemployment), the effect of job security measures on employment is ambiguous. While in the joint and LAC samples, advance notice and indemnities for dismissal have positive, although not statistically significant coefficients, the coefficient on indemnities in the OECD sample is negative and statistically significant at conventional levels. Seniority pay is positively associated with employment and the coefficients on this variable are statistically significant in most specifications. We also reject the hypothesis that the coefficients on seniority pay and the coefficients on the rest of the components of job security are the same. These differences in results across regions, specifications and samples, relative to our previous work, suggest a lack of robustness that we further explore. Before turning to a robustness analysis, we first consider the evidence on the shifting of the payroll tax.

\section{Wage shifts}


What is the estimated wage pass-through implied by our coefficients on social security contributions? The social security effect is a robust finding of our aggregate country analysis and so is worth exploring further. Define $\alpha$ as the elasticity of employment with respect to the cost of labor. Assume that social security taxes are expressed as a percentage of wages. Writing labor demand as a function of wages inclusive of taxes in log linear form, we obtain:

$$
\ln \operatorname{Emp}(S S)=\alpha \ln [W(S S)(1+S S)]+C
$$

where $S S$ is the fraction of wages marked up by social security and $W(S S)$ is the wage which depends on $S S$ through equilibrium shifting effects and $C$ is a constant standing in for all other factors. Taking derivatives with respect to the $S S$ markup, we obtain:

$$
\frac{\partial \ln E M P(S S)}{\partial \ln S S}=\alpha\left[\frac{\partial \ln W(S S)}{\partial \ln (S S)}+1\right] .
$$

Solving for $\frac{\partial \ln W(S S)}{\partial \ln S S}$, we obtain:

$$
\frac{\partial \ln W(S S)}{\partial \ln S S}=\frac{1}{\alpha}\left[\frac{\partial \ln E M P(S S)}{\partial \ln S S}-\alpha\right] .
$$

To estimate the wage shift, we estimate $\frac{\partial \ln E M P(S S)}{\partial \ln S S}$ from a specification with the same control variables as the specification reported in table 8.A, column 1, but where the dependent variable is in logs, advance notice, indemnities for dismissal and seniority pay are defined in logs and social security contributions are defined as fractions of gross wages and we use $\ln (1+S S)$ as a regressor. Finally, $\frac{\partial \ln E m p}{\partial \ln W}$ is assumed to be within the ranges 
of estimates reported in Table 4 and consistent with the estimates reported in these studies. With all of these elements, we obtain the estimates presented in Table $10 .^{30}$

We find that the elasticity of employment with respect to social security contributions is -.7 for the whole sample, around -1 for the OECD sample and -.447 for Latin America. This implies that increasing social security contributions by 10 percent will lower employment by 7 percent in the overall sample, 10 percent in the OECD and 4.5 percent in Latin America. These are large numbers. They also imply that for a large range of labor demand elasticities the estimated pass through is zero, particularly for the OECD sample. Thus, for a labor demand elasticity of -.7 , the pass through is zero in OECD and 36 percent in LA. Although this larger pass through in Latin America is at odds with the presumption of a very elastic labor supply to the formal sector, it is consistent with a much higher wage flexibility in Latin America than in industrial countries due to greater inflation in the region (see IADB, 2003). All in all, this evidence suggests that part of the cost of regulations is borne by workers, but that social security contributions tend to be perceived as taxes on labor. Increasing social security taxes leads to substantial costs in terms of reductions in employment and increases in unemployment.

\section{The effect of recent social security reforms}

Our negative coefficients on social security contributions suggest that the benefits associated with these contributions are valued at less than 100 percent of their cost. An interesting question is whether the recent wave of pension reforms in Latin America have contributed to strengthen the link between contributions and benefits as well as to increase the size of the wage pass-through. This is especially relevant because most reforms

\footnotetext{
${ }^{30}$ Hamermesh (1993) reports a range of elasticities between -.15 and -.7. We constrain wage effects of SS in
} 
transformed pay-as-you-go systems into full or partial capitalization systems. To examine this possibility we create a dummy variable Reform, which, for each country, takes the value of zero in the period pre-reform and 1 from the period of reform onward. We add this variable and an interaction of reform with the cost of social security payments to the specification given by expression (2). Our results suggest contemporaneous positive effects of pension reforms on employment. (See Table 11) However, it is unclear whether this positive effect is associated with the reforms themselves or with other factors. Thus, we find a positive and statistically significant coefficient on the Reform variable, suggesting an increase in employment rates in the post-reform period. However, the interaction term with social security reform is negative and statistically significant, indicating that social security taxes have larger disemployment effects after the reforms. This higher disincentive could be due to the mixed effects resulting from the transition to the new system. As workers move from the pay-as-you-go to the capitalization system, contributions to social security finance individual accounts and, in many instances, the pensions of those left in the old system. The contribution to fund the old system is likely to be viewed as a pure tax on employment.

\section{Robustness}

The results reported in this section are based on larger samples and depart substantially from those reported in Heckman and Pagés (2000). ${ }^{31}$ Unfortunately, a lack of robustness to changes in specification or sample size is all too common in the cross-section time-series literature that uses aggregate data. However, fragility is not the entire story.

\footnotetext{
Table 10 to be non-positive.

${ }^{31}$ We are greatly indebted to David Bravo and Sergio Urzua, who made us aware that adding Chile to the original sample used in Heckman and Pagés (2000) substantially changes our earlier conclusions.
} 
The estimated payroll tax effects are robust as are the negative effects of indemnities on employment. Given this potential weakness, we investigate whether our new results are robust to changes in estimation method, measures of regulations, specification and sample size, as well as to the exclusion of outliers.

Given the limited variance of the job security variables, it is interesting to compare our fixed effects coefficients with the results obtained from estimating our main equation using random effects (RE) (see Table 12) We reject the hypothesis of consistency of the RE estimator for employment in the joint sample at 10 percent. The most substantial difference is the considerably smaller magnitude of the coefficient on indemnities for the OECD sample in the RE model. While in the OECD sample we still find a negative effect of indemnities on employment and a positive effect on unemployment, these effects are no longer statistically significant at conventional levels. The coefficient on advance notice is now positive and statistically significant in the employment regressions and negative and statistically significant in the unemployment regressions. The size and significance of the social security contribution coefficients are robust to the change in method of estimation.

In unreported results available upon request, we also examine whether our results are robust to alternative measurements of the cost of regulations that do not require assumptions about discount or layoff rates. Following Lazear (1990), we measure job security regulations as the mandatory amount (in multiples of monthly wages) that should be paid to a worker who is dismissed after 10 years of tenure. A major disadvantage of this measure is that it only reflects job security in one point of the job security-tenure schedule. In our samples both his measure and our measure yield similar results.

We also assess the sensitivity of our results to the inclusion or exclusion of additional control variables such as year effects, region-specific year effects, time trends 
and region-specific time trends. The results on the effect of social security contributions on employment and unemployment are very robust to changes in specification. Other results are less robust. For instance, in a specification with region-specific year fixed-effects the coefficient on seniority pay is still positive but it is no longer statistically significant at conventional levels. Adding or deleting either g or GDP levels does not change our conclusions.

Important differences also arise when we assess the sensitivity of our baseline results to changes in sample size. In particular, we find that both the coefficients on advance notice provisions and indemnities for dismissal are sensitive to the inclusion/exclusion of some countries in the sample while the coefficients on social security payments and seniority pay do not change. For instance, excluding Germany from the sample greatly increases the coefficient on advance notice in the baseline employment specification. Similarly, excluding Brazil or Peru changes the coefficient on indemnities for dismissal in the employment regressions.

Finally, we check whether our results are robust to the exclusion of outliers, which are defined as those observations for which the difference in the regression coefficient when the $i$-th observation is included and when it is not, scaling the difference by the estimated standard error of the coefficient, is larger than $2 / \sqrt{n}$ (Belsley, et al., 1980). Our results confirm that there are no outliers that alter the coefficients for social security contributions. There are a few outliers that modify the coefficients on job security provisions (advance notice, indemnities and seniority pay). However, they do not qualitatively alter our baseline results.

Taken as a whole, our results suggest that the negative (and statistically significant) association between social security contributions and employment, as well as a 
positive association between social security contributions and unemployment is very robust to changes in estimation method, specification, regional sample, sample size and outliers. The coefficients on our job security measures are much less robust. Thus, while the FE estimates provide some evidence that in some OECD countries reducing indemnities results in higher employment rates, the evidence across countries provided by our RE estimates is less conclusive. One component of job security, seniority pay, is positively correlated with employment.

\section{Endogeneity}

It is often argued that labor reforms are put in place when labor market performance is poor. As demonstrated in the Figure 3 plots, this is sometimes true for reforms in the LAC region. If a decline in employment rates (and an increase in unemployment rates) prompts a reduction in labor market regulations, then least squares estimates will be upward biased, potentially underestimating a negative relationship between job security or social security taxes and employment. Our baseline specification partly controls for the possibility of such reverse causality because the propensity for reform is partly captured by changes in the GDP or demographic conditions. Another source of concern is the timing of reforms. If labor reforms that liberalize the labor market are undertaken at particularly bad times, an estimated negative relationship between employment and regulations could just be the consequence of mean reversion.

In the results available on request, we address these issues in various ways. First, we attempt to control for differences in the propensity to reform at different points in time by including current and past GDP rates up to five lags. Since presumably, bad employment outcomes are strongly associated with poor GDP outcomes, the inclusion of 
this set of variables will control for the propensity to reform. Secondly, we control for the timing of reforms by interacting changes in regulatory variables with a variable that measures the distance (in years) between the current year and the last business cycle trough. Finally, we directly address the problem of reverse causality by using the dependency ratio, defined as the ratio of population 65 and older to the population in working age (15 to 64$)$, as an instrument for social security contributions. ${ }^{32}$ Our results suggest that controlling for either the propensity or the timing of reforms does not alter the conclusions of our analysis. $^{33}$

Regarding our instrumental variable estimates, Table 13 indicates that in the three samples considered, social security contributions increase with the dependency ratio. In addition, demographic changes explain a substantial share of the within-country time variation in social security contributions. The average dependency ratio in our sample is 0.17, while in OECD and LA are 0.19 and 0.08 respectively. The coefficients in Table 13 suggest that if the dependency ratio increases in one percentage point, expected discounted social security contributions increase in 1.12 months for the total sample, 1.02 for the OECD and 2.83 for Latin America. Moreover, our instrumental variable estimates (Table 14) suggest that there is a causal relation between changes in social security contributions and changes in employment and unemployment rates at least in the overall and OECD sample. In these two samples, IV estimates produce larger coefficients than the FE regressions. Instead, the Latin America IV estimates yield coefficients with opposite signs to the ones obtained with the FE regressions. However, such coefficients are not

\footnotetext{
${ }^{32}$ The source of this data is the UN Population Statistics, 1998.

${ }^{33}$ Another way to control for endogeneity is to use the information in the Figure 3 sequence to break out episodes of reform that were not preceded by major downturns (or upturns) of the economy from other episodes and analyze the latter. The problem with this approach in our sample is that it uses up too many scarce degrees of freedom.
} 
statistically significant. The small number of observations available for Latin America is not sufficient to obtain precise IV estimates in this region.

\section{Summary}

Our analysis of pooled time-series cross-sections of countries underscores why the studies examining the impact of regulations in OECD countries based on such data have produced such ambiguous results. Lack of variation in the relevant policy measures and poor measures of regulation have hampered empirical analyses of the effect of regulations on labor market outcomes. To surmount these problems we have expanded the number of countries comprising the LAC region, included more within-country variation, and improved the measures of regulation. Contrary to previously reported estimates, we have found little evidence of a systematic relationship between advance notice and indemnities for dismissal on employment or unemployment in our improved and expanded sample for Latin America. Estimates vary across countries with some countries showing gains in employment after reducing job security, and others showing little benefit to the employment rate or even employment reductions after such reforms, but no clear pattern emerges from the aggregates.

However, we find robust evidence that social security contributions are not fully shifted to workers. Payroll taxation tends to reduce employment and increase unemployment rates across samples and specifications. At the aggregate level, our analyses of reforms intended to increase the link between contributions and payments show mixed results.

\section{Conclusions and Directions for Future Research}


Summarizing an entire school of thought, Freeman (2000) writes that "the institutional organization of the labor market has identifiable large effects on distribution, but modest hard-to-uncover effects on efficiency." This view is shared by many economists. However, the microevidence summarized in this volume suggests that mandated benefits and job security regulations have a substantial allocative impact both in Latin America and in OECD countries.

What policy lessons can be drawn from the essays in this volume? The evidence assembled in this volume suggests that labor market regulations are an inequalityincreasing mechanism, because some workers benefit while many others are hurt. The benefits of programs funded with mandatory payroll contributions should be weighed against their costs in terms of employment. Funding such programs with general revenues does not necessarily reduce employment costs (see Nickell, 1997), but strengthening the link between payments and benefits contributes to shifting the cost of such programs to workers, at least in the long run. Regulation acts unevenly across different groups in society. Young, uneducated, and rural workers are much less likely to enjoy coverage than older, skilled and urban workers.

While the aggregate evidence on the effects of job security on the level of employment is inconclusive, the microstudies assembled here find a large and negative effect of job security on employment. Individual country studies based on microdata reduce the fragility and lack of robustness problems that pervade the cross-section of countries time-series literature.

\section{Lessons For Future Research}


While these essays demonstrate that firms and workers respond to incentives in predictable ways, and that regulation reduces employment and labor market turnover, more precise quantitative estimates would be desirable. We conclude with a discussion of the main areas in which future research could improve upon the current estimates.

\section{(a) Incidence of Payroll Taxes and General Equilibrium}

Several essays in this volume take significant steps towards addressing whether workers accept lower wages if they receive mandated benefits. These estimates of incidence can be improved. Comparing the wages of covered and uncovered sectors to see if covered workers get lower wages, as in Cardenas and Bernal (this volume) and several other essays in this volume, fails to control for self-selection into these sectors which several studies in this volume have documented to be important. The method fails to adjust for general equilibrium effects arising from induced entry and exit and the willingness of workers to purchase benefits by accepting reduced wages.

The most comprehensive approach to the incidence question is the analysis of Marrufo (2001), which finds that controlling for self-selection and accounting for general equilibrium effects substantially affects estimates of tax incidence and difference-indifference estimates understate the true extent of wage adjustment. As argued by Kugler, the simple difference-in-differences method is downward biased so that the estimates reported in this volume are conservative.

\section{(b) Dynamic Labor Demand}

The empirical models of labor demand estimated by the authors in this volume are traditional static models and dynamic labor demand models based on the assumption of symmetric adjustment costs. They abstract from the asymmetries in labor demand that are

produced by severance and indemnity systems. Appendix B sketches out the main ideas in 
the asymmetric demand literature using a two-period model. Alonso-Borrego and Aguirregabiria (1999) develops the econometrics needed to estimate such models but the methods remain to be implemented on LAC data. Given that all of the labor demand models estimated in this book assume symmetric adjustment costs, it would be productive to rework these studies using more advanced methods. As previously noted, the inconclusive evidence on the effect of job security on firm adjustment dynamics may be an artifact of the symmetry assumption.

In this class of models, it would also be useful to account for general equilibrium effects of entry and exit of firms. Hopenhayn and Rogerson (1993) demonstrate that in principle accounting for general equilibrium effects can reverse the predictions of partial equilibrium models.

\section{(c) Accounting for Nonstationarity}

All of the duration models used to determine the impacts of regulation on labor market turnover assume stationary environments. Any student of Latin America knows how poor that assumption is. The high volatility of economic outcomes in Latin America suggests that this assumption does not adequately characterize the region. Accounting for nonstationarity more systematically would improve econometric estimates of behavioral parameters for the region.

\section{(d) Accounting for The Effects of Regulation on Output}

All the labor demand studies estimate output-constant wage elasticities. Abstracting from the potentially important econometric problem of endogeneity of output, outputconstant demand functions are more robust because they allow the analyst to abstract from product market adjustments to relative price changes. At the firm level, the output-constant effects of regulation understate the total effect of regulation if regulation raises the 
marginal cost of labor to the firm and costs cannot be shifted onto wages or other factor costs. The estimates reported here underestimate the full disemployment effects of deregulation in sectors adversely impacted. At the level of the national economy, the effects are more ambiguous because the burden of regulation may impact industries differently although it will still have efficiency losses by distorting sectoral allocations. In a closed economy, relative output prices adjust and will lead to an expansion of output in those sectors least impacted. So in those sectors, greater regulation may lead to greater employment. In an open economy facing world prices, when regulations are not accommodated by a downward adjustment of factor prices, regulation reduces output and accentuates reductions in employment.

A complete analysis of the impact of regulation would require accounting for both product market and factor market adjustments. The presumption is that a full account would produce disemployment effect of regulation on the overall economy but not necessarily in each sector.

Notice, however, that even if wages adjust fully and there are no adverse effects of regulation on labor demand, regulation may still have substantial effects on the welfare of workers. If a job security mandate is offset by lower wages, worker welfare is not necessarily improved, at least not for all workers. It may be higher or lower depending on how much the mandate differs from what workers and firms would mutually agree upon in an unregulated environment.

\section{(e) Accounting for serial correlation}

While most of the studies summarized in this volume measure the cost of regulations by elaborating direct monetary measures of their cost to employers, several authors use the length of the lag (the speed of adjustment) as an alternative measure of the 
cost of regulation facing the firm. The intuition supporting this is based on the original work of Holt, Modisliani, Muth, and Simon (1960), as previously described in section 4.2.

In the simple model of equations (2) and (3), if we introduce an error term, and an implicit theory of optimal employment as a function of the real wage $W_{t}$, we obtain

$$
n_{t}^{*}=a+b W_{t}+\varepsilon_{t}, \quad b \leq 0 .
$$

If $\varepsilon_{t}$ is serially correlated, we obtain

$$
\varepsilon_{t}=\rho \varepsilon_{t-1}+u_{t}
$$

where $u_{t}$ has zero mean and is independently and identically distributed and $\rho$ is the first order serial correlation. Analysts obtain a high estimated value of $\lambda$ (the coefficient on lagged labor) from a least squares estimation that does not correct for serial correlation since

$$
n_{t}=(1-\lambda)\left(a+b W_{t}\right)+\lambda n_{t-1}+(1-\lambda) \mathcal{E}_{t}
$$

If $1<\lambda<1, \rho>0$, OLS estimates of $\lambda$ are upward biased. An asymptotically unbiased estimator that accounts for this serial correlation is based on

$$
n_{t}=(1-\lambda)(1-\rho) a+(1-\lambda) b\left(W_{t}-\rho W_{t-1}\right)+(\lambda+\rho) n_{t-1}-\lambda \rho n_{t-2}+(1-\lambda) u_{t}
$$

which is derived from (6) by lagging it one period, solving for $(1-\lambda) \mathcal{E}_{t-1}$, writing $\varepsilon_{t}=\rho \varepsilon_{t-1}+u_{t}$ in (6) and substituting for $\varepsilon_{t-1}$. This bias is especially important in making cross country comparisons where serial correlation coefficients may differ greatly across economies. For studies of regulations in a single country, this bias will not affect estimates of the relative cost of different reforms if the serial correlation pattern is invariant across reforms. However, no meaning can be attached to the absolute value of the lag coefficient. This conventional model assumes symmetric hiring and firing costs. Yet even in the original Holt et al study, this assumption was only introduced as a mathematically simplifying one that was contrary to their evidence. A more accurate description of the 
data from Latin America and other regions is that there are substantial asymmetric adjustment costs.

A measurement model accounting for asymmetric adjustment costs requires a new econometric approach. In work available on request, we consider a model of asymmetric hiring and firing costs based on Hopenhayn and Rogerson (1993). The coefficient on lagged labor is not necessarily monotonic in the cost of labor regulations. This may account for the ambiguous evidence on the impact of regulation on the cost of adjustment obtained from the conventional estimates. ${ }^{34}$

\section{Taking Stock}

Although there is clearly room for improvement, the body of evidence summarized in this chapter, and reported in this book, demonstrates that regulation matters, that the choice of labor market institutions matters and that further labor reforms offer the promise of promoting both efficiency and equity across demographic groups in Latin America.

They demonstrate the power of microdata to answer important questions when the evidence from cross-country macro-time series is ambiguous.

\footnotetext{
${ }^{34}$ The intuition behind this result is simple. Different serial correlation-fixed cost pairs produce the same lagged employment coefficient. This is also possible in the simple model (6). So it is possible that a regime with higher labor transition costs is also one with lower serial correlation in shocks and so would display a lower estimated lag and a faster adjustment rate. See Barbarino and Heckman (2003).
} 


\section{References}

Abowd, J., F. Kramarz, T. Lemieux, and D. Margolis, 1997. "Minimum Wages and Youth Employment in France and The United States," National Bureau of Economic Research Working Paper 6111, July.

Abowd, J., F. Kramarz and D. Margolis, 2000. "Minimum wages and Employment in France and The United States," National Bureau of Economic Research Working Paper 6996.

Abowd, J., F. Kramarz, D. Margolis, and T. Phillippon, 2000. "The Tail of Two Countries: Minimum Wages and Employment in France and the United States," Institute for the Study of Labor (IZA) Discussion Papers No. 203.

Abraham, K. and S. Houseman, 1993. "Job Security and Work Force Adjustment: How Different are U.S. and Japanese Practices?” In Christoph F. Buechtemann ed. Employment Security and Labor Market Behavior - Interdisciplinary Approaches and International Evidence, Ithaca, NY: ILR Press, 180-199

Acemoglu D. and J. Angrist, 2001. "Consequences of Employment Protection? The Case of the Americans with Disabilities Act." Journal of Political Economy 109(5): 91557

Addison, J.T. and J.L. Grosso, 1996. “Job Security Provisions and Employment: Revised Estimates.” Industrial Relations. 35(4). ,2000. “The Effect of Dismissals Protection on Employment: More on a Vexed Theme," Southern Economic Journal 67(1): 105-22.

Addison, J.T. and P. Portugal, 1992. “Advance Notice: From Voluntary Exchange to Mandated Benefits.” Industrial Relations 31(1), 159-78. 
Addison, J. and P. Teixeira, 2001. “The Economics of Employment Protection,” IZA Discussion Paper 381, October.

Addison, J. T., P. Teixeira, and J.L. Grosso, 2000. "The Effect of Dismissals Protection on Employment: More on a Vexed Theme.” Southern Economic Journal 67; 105-22.

Alonso-Borrego, C. and V. Aguirregabiria, 1999. "Labor Contracts and Flexibility: Evidence from a Labor Market Reform in Spain." Universidad Carlos III de Madrid, Working Paper No. 99-27.

Autor, D. H., J. Donohue III, and S. Schwab, 2003. “The Costs of Wrongful Discharge Laws.” NBER Working Paper w9425, Cambridge, Mass: National Bureau of Economic Research.

Barbarino, A. and J. J. Heckman, 2003. "A Framework for the Study of the Effects of Labor Market Policies with Asymmetric Costs and Entry and Exit," Unpublished working paper. University of Chicago, Department of Economics.

Belsley, D. A., E. Kuh, and R. E Welsch, 1980. Regression diagnostics: identifying influential data and sources of collinearity. New York: Wiley.

Bentolila, S. and G. Bertola, 1990. "Firing Costs and Labour Demand: How Bad is Eurosclerosis?" Review of Economic Studies. 57. 381-402.

Bentolila, S. and G. Saint-Paul, 1994. “A Model of Labor Demand With Linear Adjustment Costs.” Labour Economics. (1):303-26.

Bertola, G., 1990. “Job Security, Employment and Wages.” European Economic Review. 34:851-86.

Bertola, G., 1992. "Labor Turnover Costs and Average Labor Demand,” Journal of Labor Economics 10(4): 389-411 
Bertola, G., 2001. “Aggregate and Disaggregated Aspects of Employment and Unemployment,” European University, April.

Blanchard, O., 1998. “Thinking about Unemployment” Mimeo. and J. Wolfers, 2000. “The Role of Shocks and Institutions in the Rise of European Unemployment: The Aggregate Evidence,” Economic Journal. 11, 1-33. De Pelsmacker, P., 1984 “ Long-Run and Short-Run Demand for Factors of Production in the Belgian Industry" In D. Vitry and B. Marechal, editors. Emploi-Chomage: Modelisation et Analyses Quantitatives. Dijon: Librairie de la Université.

Deleire, T., 2000. "The Wage and Employment Effects of the Americans with Disabilities Act," Journal of Human Resources 35(4): 693-715.

Denny, M., M. Fuss, and L. Waverman, 1981. "Estimating the Effects of Diffusion of Technological Innovations in Telecommunications: The Production Structure of Bell Canada.” Canadian Journal of Economics. 14:24-43.

Di Tella, R., and R. MacCulloch, 1999. “The Consequences of Labor Market Flexibility: Panel Evidence Based on Survey Data.” Unpublished paper, Harvard Business School.

Dolado, J., F. Kramarz, S. Machin, A. Manning, D. Margolis, and C. Teulings, 1996. "The Economic Impact of Minimum Wages in Europe" Economic Policy October 23 1996. pp 319-372.

Downes, A. et al., 2000. "Labor Market Regulation and Employment in the Caribbean." Research Network Working Paper R-388. Washington, D.C., United States: InterAmerican Development Bank.

Edwards, S. and A. Cox-Edwards, 1999. "Social Security Reform and Labor Markets: The Case of Chile.” Los Angeles, Long Beach, and Cambridge, United States: 
University of California at Los Angeles, National Bureau of Economic Research, and California State University. Mimeographed document.

Edwards, S. and A. Cox-Edwards, 2000. "Social Security Reform and Labor markets: The Case of Chile," Economic Development and Cultural Change. 50(3): 465-489.

Elmeskov, J, J.P. Martin and S. Scarpetta, 1998. “ Key lessons from Labor Market Reforms: Evidence from OECD Countries' Experience.” Swedish Economic Policy Review. 5(2): 207-252.

Fajnzylber, P. and W.F. Maloney, 2000. "Labor Demand and Trade Reform in Latin America." Belo Horizonte, Brazil, and Washington, D.C., United States:

Universidade Federal de Minas Gerais, World Bank. Mimeographed document.

Field, B. and C. Grebenstein, 1980. "Capital Energy Substitution in U.S. Manufacturing." Review of Economics and Statistics. 70:654-59.

Freeman, R.B., 2000. "Single Peaked vs. Diversified Capitalism: The Relation Between Economic Institutions and Outcomes,” NBER Working Paper 7556. Cambridge, United States: National Bureau of Economic Research. , 2001. "Institutional Differences and Economic Performance Among OECD Countries." Papers presented at the Bank of Portugal Conference Labor Market Institutions and Economic Outcomes. Cascais, Portugal.

Garibaldi, P. and Paulo Mauro, 1999. "Deconstructing Job Creation.” International Monetary Fund Working Paper WP/99/109.

Grubb, D. and W. Wells, 1993. "Employment Regulation and Patterns of Work in EC Countries.” OECD Economic Studies No. 21. Winter.

Gruber, J., 1994. "The Incidence of Mandated Maternity Benefits". American Economic Review 84(3), 622-41 
Gruber, J., 1997. “The Incidence of Payroll Taxation: Evidence from Chile.” Journal of Labor Economics 15(3) (Part 2 July), S72-101.

Hamermesh, D. S., 1993. Labor Demand. Princeton, N.J. United States: Princeton University Press.

Heckman, J., 2003. "Flexibility, Job Creation and Economic Performance," in Knowledge, information, and expectations in modern macroeconomics : in honor of Edmund $S$. Phelps. P. Aghion, R. Frydman, J. Stiglitz and M. Woodford, eds. Princeton, NJ: Princeton University Press.

Heckman, J. and C. Pagés, 2000. “The Cost of Job Security Regulation: Evidence from Latin American Labor Markets." Economia: the Journal of the Latin American and Caribbean Economic Association. 1(1), 109-154.

Holt, C.C., F. Modigliani, R. Muth and H. Simon, 1960. Planning Production, Inventories, and Work Force. Englewood Cliffs, NJ: Prentice-Hall.

Hopenhayn, H. and R. Rogerson, 1993. “Job Turnover and Policy Evaluation: A General Equilibrium Analysis.” Journal of Political Economy. 101(5), 915-38.

Inter American Development Bank (IADB), 1996. Economic and Social Progress Report. Washington DC. November.

V Inter American Development Bank (IADB), 1998-1999. Economic and Social Progress Report. Washington DC. November.

Inter American Development Bank (IADB), 2003. Economic and Social Progress Report. Washington DC. October.

International Labour Organization (ILO), 1997-1998. World Labour Report. Geneva Kaestner, R., 1996. "The Effect of Government-Mandated Benefits on Youth Employment," Industrial and Labor Relations Review 50(1): 122-42. 
Krusell P., and A. Smith, Jr., 1997. "Income and Wealth Heterogeneity, Portfolio Choice and Equilibrium Asset Returns.” Macroeconomic Dynamics 1, 387--422.

Kugler A., J. F. Jimeno and V. Hernanz, 2002 "Employment Consequences of Restrictive Permanent Contracts: Evidence from Spanish Labor Market Reforms” IZA Discussion Paper Series. No 657 Germany.

Lazear, E., 1990. “Job Security Provisions and Employment.” Quarterly Journal of Economics 105(3), 699-726

Lindauer, D., 1999. Labor Market Reforms and the Poor. Unpublished paper available at http://www.worldbank.org/poverty/wdrpoverty/background/lindauer.pdf

Lora, E. and C. Pagés, 2000. "Hacia un envejecimiento responsable: Las reformas de los sistemsas pensionales América Latina.” Cuadernos Económicos de I.C.E. No 65. 283-324.

MacIsaac, D. and M. Rama, 1997. "Determinants of Hourly Earnings in Ecuador: The Role of Labor Market Regulations.” Journal of Labor Economics. 15(3-Part Two).

Machin, S. and M. Stewart, 1996. "Trade Unions and Financial Performance," Oxford Economic Papers 48, 213-241

Marquéz, G., 1998. "Protección al empleo y funcionamiento del mercado de trabajo: una aproximación comparativ.“ Mimeo Inter-American Development Bank.

Marquéz, G. and C. Pagés, 1998. "Ties That Bind: Employment Protection and Labor Market Outcomes in Latin America.” Research Network Working Paper 373. Washington, D.C. United States: Inter-American Development Bank.

Marrufo, G., 2001. "The Incidence of Social Security Regulation: Evidence from the Reform in Mexico" Ph.D Dissertation. University of Chicago. 
Nickell, S., 1997. “Unemployment and Labor Market Rigidities: Europe versus North America." Journal of Economic Perspectives. 11(3): 55-74. and R. Layard, 1999. "Labor Market Institutions and Economic Performance," in Handbook of labor economics. Volume 3C, O. Ashenfelter and D. Card, eds. New York: North-Holland. 3029-84.

Nicoletti, G. and S. Scarpetta, 2001 "Interactions between Product and Labor Market Regulations: Do they affect Unemployment? Evidence from OECD Countries" Paper presented at the Bank of Portugal Conference Labor Institutions and Economic Outcomes. Cascais, Portugal (June 3, 2001).

Nicoletti, G. and S. Scarpetta, 2003. "Regulation, Productivity and Growth: OECD Evidence," Economic Policy No. 36 (April): 9-51, 54-69

Nicoletti, G., S. Scarpetta, and O. Boylaud, 1999. "Summary Indicators of Product Market Regulation with an Extension to Employment Protection Legislation." Working Paper No. 226. Paris: Organization for Economic Co-operation and Development.

Nohlen D. Enciclopedia Electoral Latinoamericana y del Caribe. Instituto InterAmericano de Derechos Humanos, 1993.

O’Connell, L., 1999. “Collective Bargaining Systems in Six Latin American countries: Degrees of Autonomy and Decentralization.” Research Network Working Paper R399. Washington, D.C., United States: Inter-American Development Bank.

OECD, 1993. Employment Outlook. Paris, France.

OECD, 1994. The OECD Jobs Study: Facts, Analysis, Strategies, Paris: Organization for Economic Co-operation and Development. 
OECD, 1999. "Employment Protection and Labour Market Performance." OECD

Economic Outlook. Chapter 2. Paris : Organisation for Economic Co-operation and Development. 49-132.

Pagés, C. and C. Montenegro, 1999. "Job Security and the Age-Composition of Employment: Evidence from Chile.” Working Paper 398. Washington, D.C., United States: Inter-American Development Bank.

Risager, O and J. R. Sorensen 1997, "On the Effects of Firing Costs When Investment is Endogeneous: An Extension of a Model by Bertola”. European Economic Review 41(7): $1343-53$

Roberts, M.J. and E. Skoufias, 1997.’The Long-Run Demand for Skilled and Unskilled Labor in Colombian Manufacturing Plants." Review of Economics and Statistics 79(2), 330-34.

Scarpetta, S., 1996. “Assessing the Role of Labour Market Policies and Institutional Settings on Unemployment: A Cross-Country Study.” OECD Economic Studies No. 26 .

United States Social Security Administration, Division of Research and Statistics, 19831999 Social Security Programs Throughout the World. Washington, D.C. U.S. Dept. of Health and Human Services, Social Security Administration, Office of Research and Statistics.

Waud, R., 1968. "Man-Hour Behavior in U.S. Manufacturing: A Neoclassical Interpretation." Journal of Political Economy. 76:407-27.

World Bank, 2000. World Development Indicators CD-ROM. Washington, D.C.: The World Bank. 
Wylie, P., 1990. "Scale-biased Technological Development in Canada's Industrialization, 1900-1929." Review of Economics and Statistics. 72:219-27. 


\section{Appendix A: Definitions and sources of variables used in section 5}

For the empirical analysis described in section 5, we build an unbalanced panel data covering the period 1983-1999. Table A.3 describes the variables and their sources. Table A.4 describes the countries and the years covered in our sample.

\section{Computation of Labor Market Regulation Measures}

(1) Advance Notice and Indemnities for dismissal:

OECD Countries

We gather information on advance notice and indemnities for dismissal for OECD countries from the OECD Employment Outlook (1999), Table 2.A.2: Required notice and severance pay for individual dismissal, pp. 94-96, which summarizes the "case of a regular employee with tenure beyond any trial period, dismissed on personal grounds or economic redundancy but without fault". For countries for which is likely that individual dismissals be considered "unjust" (measured as those countries to which the OECD gives a score of 2 or more in a 1-3 scale in Table 2.A.4 pp.100), that, is countries where a "transfer and or retraining to adapt to different work must be attempted prior to dismissal" and where "worker capability cannot be ground for dismissal", we consider the information summarized in the "Compensation and related remedies following unjustified dismissal". From this table, and for this subset of countries, in at least one country, unjust dismissals carry a much higher penalty. This is the case of Spain. We make this contingency explicit by computing the expected severance pay assigning a $1 / 2$ probability that a dismissal will be considered unfair and will carry the higher severance pay that the law mandates in this event. We obtain information on labor reforms from Table 2.1 pp. 53 (Employment Outlook, 1999), which describes the main changes in legislation since the mid eighties. We also compare the information described in OECD (1999) with the one presented in Grubb and Wells (1993). If they diverge, we take the information in the latter to be valid up to 1993 while we take the information presented in OECD (1999) to be valid from 1997 onwards. For the years in between the index has a missing value. There are only four countries where there are some divergences between the former and the latter source. This is the case of Denmark, Greece, Netherlands and Sweden. Finally, in countries where the law prescribes different severance pay and advance notice for blue and white-collar workers we compute the cost of dismissal as the unweighted average for the two groups. For Hungary, Korea, New Zealand and Turkey the job security measures only take non-missing values from 1990 onwards since we could not find legal information for former years. To construct our index, we do not consider upper monetary limits. In addition, we do not consider benefits that firms pay or unions can obtain for their workers, which exceed the legal mandatory. Finally, we do not consider what workers can get in courts if they sue their employers.

Individual country notes: In Australia, we consider the severance pay awarded to workers dismissed for redundancy. For Canada, we take the maximum of the severance pay and advance notice mandated by the federal and the local jurisdiction. In Greece, for white-collar workers, advance notice can be waived if full severance pay is given. We thereby assume that firms pay in full to avoid paying additional advance notice. In Ireland, the awarded severance pay depends on the age of the worker. We assume that workers receive 0.18 monthly wages per year worked, which corresponds to the (unweighted) average of half a week per year worked (workers under the age of 41) and a week per year worked (workers over the age of 41). In Norway, after 10 years of tenure, 
notice period increases with age. To capture this effect, we have increased notice period from 3 months to 4 and 5 in the case of individuals of more than 15 years of tenure. For Spain, we adjust the severance pay obtained in case of just dismissal by the fact that many dismissals are considered unjust. We therefore weigh mandatory dismissals in case of just and unjust causes by a probability of $1 / 2$ for each event.

Latin America

We consider the legal information summarized in Tables A.1 and A.2 obtained from the Ministries of Labor of individual countries.

Notes: In Brazil, employers are required to deposit 8 percent of a workers' wage in individual workers' accounts, which accrue interest rates. In case of a firm initiated dismissal, firms are required to pay a worker severance pay that is a given fraction of what a worker owns in his individual account. The 1988 constitutional reform increased this share from . 1 to .4 of the total amount in the fund. To compute the fraction of what is accrued in the individual fund, we assume that the interest rate equals the discount rate. Therefore, the indemnity is computed as:

Indemnities $=\sum_{i=1}^{T} \delta^{i-1}(1-\delta)(i)$

where $i$ denotes tenure at the firm, $\delta$ is the per period probability of survival (equal to 0.88 ) and $T$ denotes the maximum tenure of a worker in a firm, which is assumed to be equal to twenty. In Honduras, Jamaica, Nicaragua and Dominican Republic, a constant advance notice equal to one month is assumed. In Peru, there were reforms in job security in 1991, 1995 and 1996. Tables A.1 and A. 2 only report the schedule as in 1990 and in 1999. See Saavedra and Torero (this volume) for a more detailed description of the changes in the Peruvian labor code throughout the nineties.

\section{(2) Seniority Pay:}

Seniority payments only exist in Latin America. There are two kinds. In Brazil, Colombia, Ecuador, and Peru, workers deposit $1 / 12$ of their monthly wages in individual accounts. In this case, seniority pay is computed as:

Senp $=\sum_{i=0}^{T} \beta^{i}$

where $T=20$. This reflects the discounted value of a stream of payments equivalent to one month of pay per year. For Colombia, Kugler (this volume) reports that before the 1990 labor reform, workers were entitled to one month of salary per year of work as a seniority fund upon separation independently of the cause of separation. However, partial withdrawals were allowed and deducted in nominal terms from the final payment, implying a "double retroactivity" with an estimated cost of 35 percent of the total payments of seniority pay in the manufacturing sector. We therefore apply a surcharge of 35 percent to the legislated scheduled for seniority pay during the period before 1990 .

Instead, in Venezuela and Panama, labor codes mandate a mandatory seniority payment that is computed as multiples of the last wage per year of work. In those cases, seniority pay is computed as: 
Senp $=\sum_{i=1}^{T} \delta^{i-1}(1-\delta)\left(\alpha_{j}^{*} i\right)$,

where $\alpha j$ denotes multiples of the last wage and $i$ denotes tenure at the firm. In Venezuela, the legal codes specified a seniority pay of one monthly wage per year of work $(\alpha j=1)$. After the 1997 , seniority pay was increased to two monthly wages per year of work $(\alpha j=2)$. Notice that this formula assumes that the probability of worker turnover is identical to the probability of job turnover. Since in general, worker turnover rates tend to be higher than job turnover rates, we also experimented with a probability of worker turnover equal to two times and three times the probability of job turnover. The cost of seniority pay declines with the rate of turnover (since the probability of surviving in the firm and obtaining larger amounts declines). Our estimated results are robust to different assumptions in the worker turnover rate.

\section{(3) Social Security Regulations:}

Information provided by Social Security Programs Throughout the World (biannually 1983-1999, US Social Security Administration. Office of Research, Evaluation and Statistics). Social security contributions include contributions by employers and employees to old age, disability and death; sickness and maternity; work injury; unemployment insurance and Family allowances programs. Since this information is only available biannually, we extend the data to yearly frequency in two alternative ways: by interpolating or by inputting each missing data values with the value in the former year. The results of our empirical analysis do not vary with the method used. The results also do not vary when we consider only the original biannual data.

For Argentina, we obtained direct information from the country. Rates apply to Buenos Aires. In all countries, we consider the rates applied to wage earners. We do not include contributions made by government to fund social security programs. In cases where contributions differ across individuals, states, or industry risk, only one rate is chosen, and the choice varies somewhat across countries. However, the same criterion is used within countries across time. This somewhat reduces cross-country comparability but preserves across time comparability within countries.

\section{(4) Social Security Reform:}

The variable Reform takes a value of 1 after a country has implemented a social security reform that totally or partially replaces a pay as you go system by an individually capitalization system. Based on social security reforms information summarized in Lora and Pages (2000) this variable takes the value of 1 in Chile on and after 1981; in Colombia on and after 1994; in Argentina on and after 1994; in Uruguay on and after 1996; in Mexico and Bolivia on and after 1997; in El Salvador on and after 1998. 
Table A.1: Legislation Concerning Termination of Indefinite Contracts in 1987 and 1999. $x=$ Monthly Wages, $N=$ Years of Tenure, $r=$ Interest Rate of Fund

\begin{tabular}{|c|c|c|c|c|c|c|c|}
\hline & \multirow{2}{*}{$\begin{array}{l}\text { Date of } \\
\text { Reform }\end{array}$} & \multicolumn{2}{|c|}{ Advance notice } & \multicolumn{2}{|c|}{ Seniority premium } & \multicolumn{2}{|c|}{ Compensation if worker quits? } \\
\hline & & 1987 & 1999 & 1987 & 1999 & 1987 & 1999 \\
\hline Argentina & None & 1-2 months & No changes & 0 & 0 & 0 & 0 \\
\hline Bahamas & None & $1 / 2-1$ month & No changes & 0 & 0 & 0 & 0 \\
\hline Barbados & None & $\begin{array}{c}\text { Negotiable, } \\
\text { in practice } \\
1 \text { month }\end{array}$ & No changes & 0 & 0 & 0 & 0 \\
\hline Belize & None & $1 / 2-1$ month & No changes & 0 & 0 & $\begin{array}{l}1 / 6 x * N \\
\text { if } N>10\end{array}$ & No changes \\
\hline Bolivia & None & 3 months & No changes & 0 & 0 & $\begin{array}{c}1 x^{*} N \\
\text { if } N>=5\end{array}$ & No changes \\
\hline Brazil & 1988 & 1 month & No changes & $\begin{array}{c}\text { FUND } \\
\text { (8\% wage } \\
\text { goes to } \\
\text { FUND, plus } \\
\text { interest rate) }\end{array}$ & $\begin{array}{c}\text { No } \\
\text { Changes }\end{array}$ & 0 & 0 \\
\hline Chile & 1991 & 1 month & No changes & \begin{tabular}{|l|}
0 \\
\end{tabular} & 0 & No & $\begin{array}{c}1 / 2 x^{*} N(*) \\
\text { if } N>=7\end{array}$ \\
\hline Colombia & 1990 & 15 days & No changes & $x * N$ & $\begin{array}{c}\text { FUND } \\
(8 \% \\
\text { wage }+r)\end{array}$ & $\mathrm{x} * \mathrm{~N}$ & $\begin{array}{c}\text { FUND } \\
(8 \% \text { wage }+r)\end{array}$ \\
\hline Costa Rica & None & 1 month & No changes & 0 & 0 & 0 & 0 \\
\hline \begin{tabular}{|l|} 
Dominican \\
Republic
\end{tabular} & 1992 & $1 / 4-1$ month & No changes & 0 & 0 & 0 & 0 \\
\hline Ecuador & 1991 & 1 month & No changes & $\begin{array}{c}\text { FUND } \\
(8 \% \text { wage } \\
+r)\end{array}$ & $\begin{array}{c}\text { No } \\
\text { Changes }\end{array}$ & $\begin{array}{c}\text { FUND } \\
(8 \% \text { wage }+r)\end{array}$ & No changes \\
\hline \begin{tabular}{|l} 
El \\
Salvador
\end{tabular} & 1994 & $0-7$ days & No changes & 0 & 0 & 0 & 0 \\
\hline Guatemala & None & 0 & No changes & 0 & 0 & 0 & 0 \\
\hline
\end{tabular}

$\left({ }^{*}\right)$ workers can choose between getting an unconditional payment after 7 years in the firm, or getting a higher indemnity in case of dismissal. Most workers opt for the latter.

FUND: A certain fraction of a worker's wage is deposited in an individual account every month. The principal plus the interest can be withdrawn by the worker upon dismissal and in some cases, upon voluntary separation. 
Table A.1: Legislation Concerning Termination of Indefinite Contracts in 1987 and 1999. $x=$ Monthly Wages, $N=$ Years of Tenure, $r=$ Interest Rate of Fund . (Continuation)

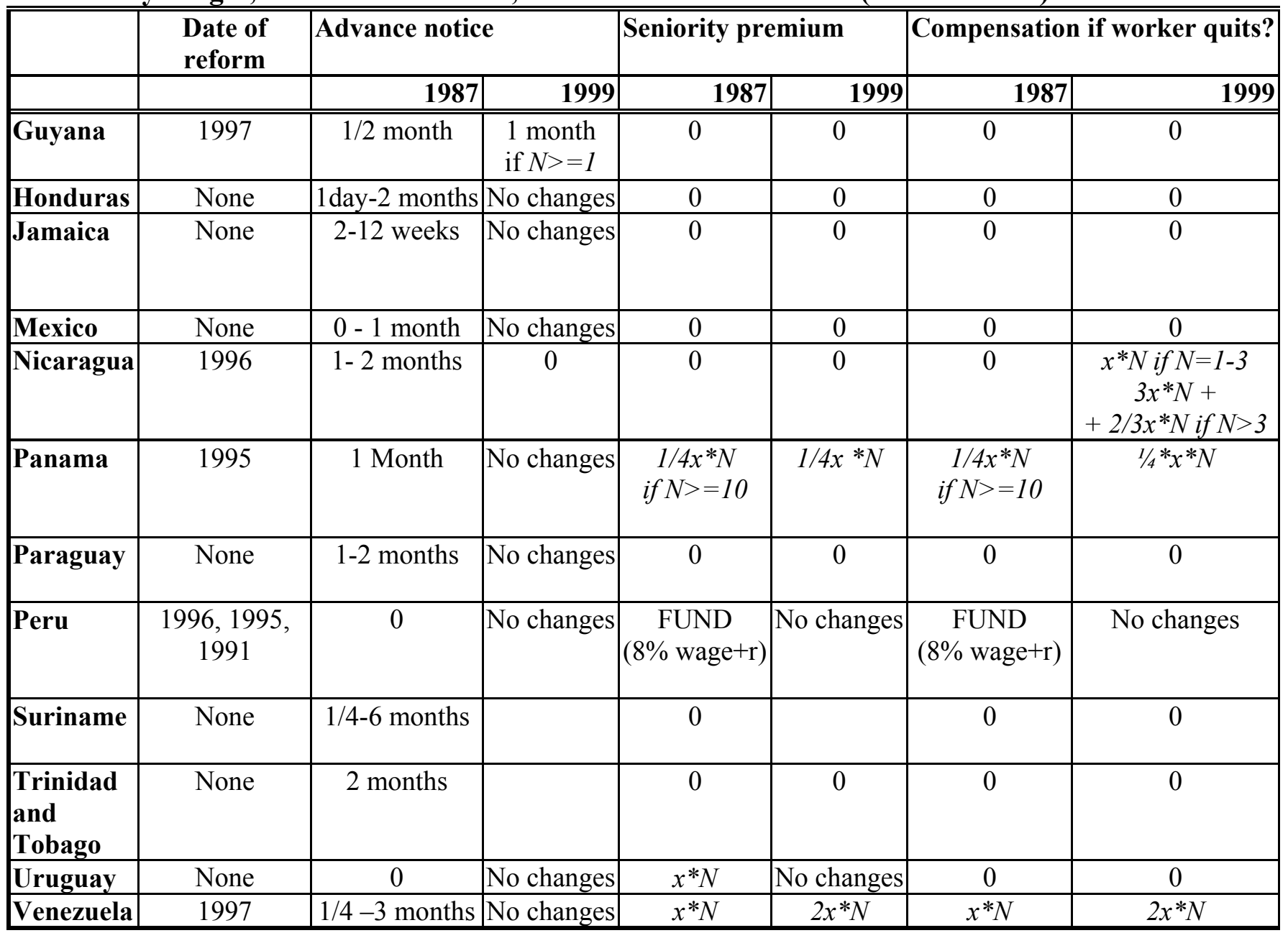

FUND: A certain fraction of a worker's wage is deposit in an individual account every month. The principal plus the interest can be withdrawn by the worker upon dismissal and in some cases, upon voluntary separation.

Source: Ministries of Labor in Latin America and the Caribbean 
Table A.2: Legislation Concerning Indemnities for Dismissal in 1987 and 1999. $x=$ Monthly Wages, $N=$ Years of Tenure, $\quad r=$ Interest Rate of Fund

\begin{tabular}{|c|c|c|c|c|c|c|}
\hline & \multirow[t]{2}{*}{$\begin{array}{l}\text { Date of } \\
\text { reform }\end{array}$} & \multicolumn{2}{|c|}{$\begin{array}{c}\text { Compensation for dismissal due to } \\
\text { economic reasons }\end{array}$} & \multirow[t]{2}{*}{$\begin{array}{l}\text { To whom do the } \\
\text { reforms apply? }\end{array}$} & \multicolumn{2}{|c|}{$\begin{array}{c}\text { Upper limit to } \\
\text { compensation for } \\
\text { dismissal? }\end{array}$} \\
\hline & & 1987 & 1999 & & 1987 & 1999 \\
\hline Argentina & None & $2 / 3 x * N$, Min 2 months & No changes & & Max. lim. in $\mathrm{x}$ & No changes \\
\hline Bahamas & None & Negotiable & No changes & & \begin{tabular}{|l|} 
No \\
\end{tabular} & No changes \\
\hline Barbados & None & $\begin{array}{l}0.41 x * N \\
\text { if } N>=2\end{array}$ & No changes & & $\begin{array}{l}3.75 \text { monthly } \\
\text { salaries }\end{array}$ & \\
\hline Belize & None & $\begin{array}{l}1 / 4 x * N \\
\text { If } N>5\end{array}$ & No changes & & Max 42 weeks & No changes \\
\hline Bolivia & None & $1 x^{*} N$ & No changes & & No & No changes \\
\hline Brazil & 1988 & $0.1 * F U N D$ & $0.4^{*} F U N D$ & All Workers & No & No changes \\
\hline Chile & 1991 & $1 x * N$ & No changes & All workers & $\begin{array}{l}5 \text { monthly } \\
\text { salaries }\end{array}$ & $\begin{array}{l}11 \text { monthly } \\
\text { salaries }\end{array}$ \\
\hline Colombia & 1990 & $\begin{array}{l}\quad 45 \text { days }+ \\
\quad x * N * 0.5 \text { if } N<5 \\
x * N * 0.66 \quad \text { if } \quad N \geq 5 \& \\
N<10 \\
x * N \text { if } N \geq 10\end{array}$ & \begin{tabular}{|c|}
45 days + \\
$x * N^{*} 0.5$ if \\
$N<5$ \\
$x * N^{*} 0.66$ if \\
$N \geq 5 \& N<10$ \\
$x * N^{*} 1.33$ if \\
$N \geq 10$
\end{tabular} & All workers & No & No changes \\
\hline Costa Rica & None & $x * N$ & No changes & & 8 monthly sal. & No changes \\
\hline $\begin{array}{l}\text { Dominican } \\
\text { Republic }\end{array}$ & 1992 & $1 / 2 * x * N$ & $\begin{array}{c}.67 x * N \text { if } \\
N=1-4 \\
.74 x * N \text { if } \\
N>=5\end{array}$ & New employees & No & No changes \\
\hline Ecuador & 1991 & $\begin{array}{c}2 \text { if } N<=2 \\
4 \text { if } N=2-5 \\
6 \text { if } N=5-20 \\
12 \text { if } N>20\end{array}$ & $\begin{array}{c}3 \text { if } N<=3 \\
x^{*} N \text { if } N>3\end{array}$ & All workers & $\begin{array}{l}12 \text { monthly } \\
\text { salaries. }\end{array}$ & $\begin{array}{l}25 \text { monthly } \\
\text { salaries }\end{array}$ \\
\hline El Salvador & 1994 & $\begin{array}{c}x^{*} N \\
0 \text { if bankruptcy }\end{array}$ & $\begin{array}{c}\quad x * N \\
\text { Changes } \\
\text { in max. } \mathrm{x}\end{array}$ & All workers & $\begin{array}{c}\text { Max. base } \\
\text { wage= } \\
4 \text { min. wages }\end{array}$ & No changes \\
\hline Guatemala & None & $\begin{array}{l}2 \text { days-4months if } \\
\text { bankruptcy. } X^{*} N \\
\text { otherwise }\end{array}$ & No changes & & No & No changes \\
\hline
\end{tabular}


Table A.2: Legislation Concerning Indemnities for Dismissal in case of Termination of Indefinite Contracts in 1987 and 1999.

$x=$ Monthly Wages, $N=$ Years of Tenure, $r=$ Interest Rate of Fund (Continuation)

\begin{tabular}{|c|c|c|c|c|c|c|}
\hline & $\begin{array}{l}\text { Date of } \\
\text { reform }\end{array}$ & $\begin{array}{r}\text { Compensation dismi } \\
\text { reas }\end{array}$ & $\begin{array}{l}\text { ssal due to economic } \\
\text { ons }\end{array}$ & $\begin{array}{l}\text { To whom do the } \\
\text { reforms apply? }\end{array}$ & $\begin{array}{r}\text { Upper limit to } \\
\text { for disı }\end{array}$ & $\begin{array}{l}\text { compensation } \\
\text { missal? }\end{array}$ \\
\hline & & \begin{tabular}{|l|}
1987 \\
\end{tabular} & 1999 & & 1987 & 1999 \\
\hline Guyana & 1997 & $\begin{array}{c}\text { Negotiable In practice, } \\
21 / 2 \text { weeks per } \mathrm{N}\end{array}$ & $\begin{array}{c}1 / 4 x * N \\
\text { if } \quad N=1-5 \\
1 / 2 x * N \\
\text { if } N=5-10\end{array}$ & All workers & No & $\begin{array}{l}12 \text { monthly } \\
\text { salaries }\end{array}$ \\
\hline Honduras & None & $x * N$ & No changes & & $\begin{array}{r}15 \text { monthly } \\
\text { wages }\end{array}$ & No changes \\
\hline Jamaica & None & $\begin{array}{r}1 / 3 x * N \text { if } x=2-5 \\
1 / 2 X^{*} N \text { if } x>5\end{array}$ & No changes & & No & No changes \\
\hline Mexico & None & $\begin{array}{r}2 / 3 x * N \\
(\operatorname{Min} .3 * x) \\
\end{array}$ & No changes & & No & No changes \\
\hline Nicaragua & 1996 & $\begin{array}{r}\text { Negotiated } \\
\text { In practice, } 2 x^{*} N \\
\end{array}$ & $\begin{array}{r}x * N \text { if } N=1-3 \\
3 x * N+2 / 3 x * N \text { if } N>3 \\
\end{array}$ & & No & $\begin{array}{l}5 \text { monthly } \\
\text { salaries }\end{array}$ \\
\hline Panama & 1995 & $\begin{array}{r}* N \text { if } N<=1 \\
3 x \text { if } N=2 \\
3 x+3 / 4 x * N \text { if } \\
N>2<10 \\
9 x+1 / 4 x * N \text { if } N>=10\end{array}$ & $\begin{array}{r}3 / 4 x * N \text { if } N<10 \\
7.5 x+1 / 4 x * N \text { if } \\
N>=10\end{array}$ & New employees & No & No changes \\
\hline Paraguay & None & $1 / 2 x * N$ & $1 / 2 x * N$ & & No & No changes \\
\hline Peru & $\begin{array}{r}1996,1995, \\
1991 \\
\end{array}$ & $3 x * N$ & $1.5 * x * N$ & All workers & $\begin{array}{r}12 \text { monthly } \\
\text { salaries }\end{array}$ & No changes \\
\hline Suriname & None & Negotiated & Negotiated & & No & No changes \\
\hline Trinidad & None & $\begin{array}{r}1 / 3 x^{*} N \text { if } N=1-4 \\
1 / 2 x^{*} N \text { if } N>5 \\
\end{array}$ & No changes & & No & No changes \\
\hline Uruguay & None & $x * N$ & No changes & & $\begin{array}{r}6 \text { monthly } \\
\text { salaries } \\
\end{array}$ & No changes \\
\hline Venezuela & 1997 & $2 / 3-2 x * N$ & $x * N$ & All workers & No & $\begin{array}{r}5 \text { monthly } \\
\text { salaries }\end{array}$ \\
\hline
\end{tabular}

FUND: A certain fraction of a workers' wage is deposit in an individual account every month. The principal plus the interest can be withdrawn by the worker upon dismissal and in some cases, upon voluntary separation.

Source: Ministries of labor in Latin America and the Caribbean. 


\begin{tabular}{lll}
\hline \hline Variable & Source & Description
\end{tabular}

\begin{tabular}{ll}
\hline Employment/Population & OECD Statistics and \\
& Household Surveys \\
& Data from Latin \\
& America
\end{tabular}

Unemployment

GDP growth

GDP per capita, PPP

(current international \$)

Share of WAP 25-54

Share of WAP 55-64

Advance Notice (AN)

Indemnities for Dismissal (ID)

Seniority Pay (SenP)

Social Security

Contributions (SSC)

Social Security

Contributions (ss)

UN Population

Statistics 1998

UN Population

Statistics 1998

Own Construction

US Social Security Administration
OECD Statistics and

Household Surveys

Data from Latin

America

World Bank

Development Indicators

Development Indicators
World Bank

OECD: Employment to population Rate of people 15-64. National and/or European Labour Force Surveys are the main source for the "Labour Force Statistics" database. LATIN AMERICA: Computed directly from Household Survey Data for the countries, years and sources listed in Table A.4. Employment to population rate for workers 15-65. Are considered employed all workers that declared having a job in the week of reference. It also includes unpaid workers. National data except in Argentina, Bolivia and Uruguay.

OECD: Unemployment rate of people 15-64. National and/or European Labour Force Surveys are the main source for the "Labor Market Statistics indicator" (LMSI) database, OECD.

LATIN AMERICA: \% of the labor force 15-65 that did not work in the period of reference but are actively looking for a job. National data except in Argentina, Bolivia and Uruguay.

Annual percentage growth rate of GDP at market prices based on constant local currency. Aggregates are based on constant 1995 U.S. dollars. GDP measures the total output of goods and services for final use occurring within the domestic territory of a given country, regardless of the allocation to domestic and foreign claims.

GDP per capita based on purchasing power parity (PPP). GDP PPP is gross domestic product converted to international dollars using purchasing power parity rates. An international dollar has the same purchasing power over GDP as the U.S. dollar in the United States. GDP measures the total output of goods and services for final use occurring within the domestic territory of a given country, regardless of the allocation to domestic and foreign claims.

Share of population 15 to 64 that are between 25 to 54 years old

Expected discounted cost of providing mandatory advance notice measured in multiples of monthly wages

Expected discounted cost of providing mandatory indemnities for dismissal measured in multiples of monthly wages

Expected discounted cost of providing Seniority Pay measured in multiples of monthly wages

Expected discounted cost of providing mandatory advance notice measured in multiples of monthly wages 
Table A. 4 Countries and years included in baseline specification

(Table 8.A col. $1 ; \mathrm{N}=417$ )

\begin{tabular}{|c|c|c|c|}
\hline Country & Years included in baseline specification & $\mathrm{N}$ & Source of Employment and Unemployment Data \\
\hline Argentina & $1996,1998,1999$ & 3 & Encuesta Permanente de Hogares \\
\hline Australia & 1983-1999 & 17 & LMSI, OECD \\
\hline Austria & 1983-1999 & 17 & LMSI, OECD \\
\hline Belgium & $1983-1988$ & 16 & LMSI, OECD \\
\hline Bolivia & 1986, 1990, 1993, 1995, 1996, 1997, 1999 & 7 & $\begin{array}{l}\text { Encuesta Continua de Hogares/ Condiciones de } \\
\text { Vida }\end{array}$ \\
\hline Brazil & $1983,1986,1988,1992,1993,1995-1999$ & 10 & Pesquisa Nacional de Amostra de Domicilios \\
\hline Canada & 1983-1999 & 17 & LMSI, OECD \\
\hline Chile & 1987, 1990, 1992, 1994, 1996, 1998 & 6 & Encuesta de Caracterización Socioecómica Nacional \\
\hline Colombia & $1990,1991,1993,1995,1996-1999$ & 8 & Encuesta Nacional de Hogares \\
\hline Costa Rica & $\begin{array}{l}\text { 1983, 1985, 1987, 1989, 1991, 1993, 1995, } \\
\text { 1997, } 1998\end{array}$ & 9 & Encuesta Nacional de Hogares \\
\hline $\begin{array}{l}\text { Dominican } \\
\text { Rep. }\end{array}$ & 1996,1998 & 2 & Encuesta Nacional de Fuerza de Trabajo \\
\hline El Salvador & $1995,1997,1998$ & 3 & Encuesta de Hogares de propósitos múltiples \\
\hline Finland & 1983-1999 & 17 & LMSI, OECD \\
\hline France & 1983-1999 & 17 & LMSI, OECD \\
\hline Germany & 1992-1999 & 8 & LMSI, OECD \\
\hline Greece & $1983-1993$ & 11 & LMSI, OECD \\
\hline Honduras & 1989, 1992, 1996, 1997, 1998, 1999 & 6 & $\begin{array}{l}\text { Encuesta Permanente de Hogares de Propósitos } \\
\text { Multiples }\end{array}$ \\
\hline Ireland & 1983-1999 & 17 & LMSI, OECD \\
\hline Italy & 1983-1999 & 17 & LMSI, OECD \\
\hline Japan & 1983-1999 & 17 & LMSI, OECD \\
\hline Korea & 1991-1999 & 9 & LMSI, OECD \\
\hline México & 1984, 1989, 1992, 1994, 1996, 1998 & 6 & Encuesta Nacional de Ingreso Gasto de los Hogares \\
\hline Netherlands & 1983-1992, 1997 & 11 & LMSI, OECD \\
\hline New Zealand & $1991-1999$ & 9 & LMSI, OECD \\
\hline Nicaragua & 1993,1998 & 2 & $\begin{array}{l}\text { Encuesta Nacional de Hogares sobre Medición de } \\
\text { Niveles de Vida }\end{array}$ \\
\hline Norway & $1983-1999$ & 17 & LMSI, OECD \\
\hline Panama & $1991,1995,1997,1998,1999$ & 5 & Encuesta continua de Hogares \\
\hline Paraguay & 1995,1998 & 2 & Encuesta de Hogares \\
\hline Peru & 1985, 1991, 1994, 1996, 1997, 1998 & 6 & $\begin{array}{l}\text { Encuesta Nacional de Hogares sobre Medición de } \\
\text { Niveles de Vida. }\end{array}$ \\
\hline Poland & 1991-1998 & 8 & LMSI, OECD \\
\hline Portugal & 1983-1999 & 17 & LMSI, OECD \\
\hline Spain & 1983-1999 & 17 & LMSI, OECD \\
\hline Sweden & 1983-1999 & 17 & LMSI, OECD \\
\hline Switzerland & 1983-1999 & 17 & LMSI, OECD \\
\hline Turkey & 1991-1999 & 9 & LMSI, OECD \\
\hline United & 1987-1999 & 13 & LMSI, OECD \\
\hline Kingdom & & & \\
\hline United States & $1983-1999$ & 17 & LMSI, OECD \\
\hline Uruguay & $1989,1992,1995,1997,1998$ & 5 & Encuesta Continua de Hogares \\
\hline Venezuela & $1983,1986,1989,1993,1995,1997-1999$ & 8 & Encuesta de Hogares por Muestra \\
\hline
\end{tabular}

Note: LMSI stands for Labour Market Statistics Indicators 


\section{Appendix $\mathbf{B}^{1}$}

\section{Dynamic Demand Specifications}

All of the papers on labor demand in this volume ignore the asymmetric nature of labor adjustment costs. In this appendix, we explore the consequences of this asymmetry on labor demand. The main conclusion is that static and dynamic costs of labor have separate effects on labor demand, and in general no scalar index adequately summarizes these costs. In order to specify labor demand functions in the presence of asymmetric hiring and firing costs, it is convenient to use a two period model. Such a model is implicit in Kugler (this volume). Let $f(\ell)$ denote output as a function of labor input $\ell$. Let $\theta$ be a second period productivity shock. It is normalized against a first period productivity shock of "1." We assume, for simplicity, that workers do not quit once they are hired.

Labor hired in period 1 is $\ell_{1}$. Labor employed in period 2 is $\ell_{2}=\ell_{1}+\Delta . \Delta$ is thus the change in the stock of period 1 labor. Spot wage $W$ is assumed to be common in both periods, and is assumed to be exogenous to the firm. The cost of firing a worker is $C$. Offsetting this cost is the saving in wages. The cost of hiring a worker is the wage. Asymmetry arises when $C \neq 0$. Assume no discounting. Labor $\ell_{1}$ is kept on in period 2 unless second period demand shocks $(\theta)$ are sufficiently low. The firm maximizes profits:

$$
f\left(\ell_{1}\right)-W \ell_{1}+E\left[\theta f\left(\ell_{1}+\Delta\right)-W\left(\ell_{1}+\Delta\right)-C \operatorname{Max}(-\Delta, 0)\right]
$$

where the first period labor productivity is normalized to 1.

We assume that the support of $\theta$ is $(0, \infty)$ and that $\theta$ is an (absolutely continuous) random variable. If $\theta \geq 1$ with probability 1 , the firm in the second period wants $\Delta \geq 0$. Labor productivity has increased when $\theta$ is bigger than its first period value, which implicitly is set at 1.

The presence of second period firing costs inhibits hiring in the first period. Thus, anticipating

\footnotetext{
${ }^{1}$ We thank Jagadeesh Sivadasan for helpful comments on this draft.
} 
the possibility of an adverse shock in the second period, the firm hires less labor than it would hire in the first period in the absence of firing costs. If, for the sake of making an heuristic argument, we characterize the firm as myopically maximizing period-by-period profits, the firm acts as if the first period productivity shock is less than 1 in making its first period decisions and hires less labor than it would if there were no second period firing costs. Letting $\bar{\theta}$ be the value of the "as if" first period productivity shock, if $\theta>\bar{\theta}$ in period 2 , then $\theta f^{\prime}\left(\ell_{2}\right)=W$ and $\ell_{2}=\left[f^{\prime}\right]^{-1}\left(\frac{W}{\theta}\right)>\ell_{1}$.

If $\theta=\bar{\theta}$, the firm stays put at $\ell_{1}$ so that $\ell_{1}=\ell_{2}$ and $\Delta=0$. If productivity is below $\bar{\theta}$, the firm may still keep its workforce at $\ell_{1}=\ell_{2}$ because it is costly to fire labor. We now determine the lower bound on $\theta$ that gives rise to inaction. For a fixed $\ell_{1}$, the two required conditions for inaction $(\Delta=0)$ are $\theta f^{\prime}\left(\ell_{1}\right)<W$, so it pays in gross terms to get rid of a unit of $\ell_{1}$, and $\theta f^{\prime}\left(\ell_{1}\right)>W-C$, so it does not pay in net terms. Thus the inequalities determining the zone of inaction are (for a given $\left.\ell_{1}\right)$

$$
W-C \leq \theta f^{\prime}\left(\ell_{1}\right) \leq W
$$

The lower boundary $\theta^{*}$ is $\frac{W-C}{f^{\prime}\left(\ell_{1}\right)}=\theta^{*}$. Holding $\ell_{1}$ fixed, raising $C$ lowers the threshold $\theta^{*}$. Thus the zone of inaction for a given $\left(\ell_{1}, C\right)$ is $\theta^{*} \leq \theta \leq \bar{\theta}$, where $\bar{\theta}=W /\left(f^{\prime}\left(\ell_{1}\right)\right)$.

The first order condition for $\ell_{1}$ is $f^{\prime}\left(\ell_{1}\right)-W+E\left(\theta f^{\prime}\left(\ell_{1}+\Delta\right)-W\right)=0$, where $\Delta=0$ if $\theta^{*} \leq \theta \leq \bar{\theta}$, $\Delta<0$ if $\theta<\theta^{*}$ and $\Delta>0$ if $\theta>\bar{\theta}$. From concavity, $\ell_{1}$ is decreasing in cost $C$. Intuitively, firms with high firing costs hold back on hiring $\ell_{1}$. There is an option value of holding back on hiring $\ell_{1}$ to avoid the cost of firing unwanted second period labor. In order to characterize $\ell_{1}$, we must first characterize $\Delta\left(\ell_{1}\right)$.

\section{Second Period (Conditional on $\ell_{1}$ ) Demand Functions}

Letting $\Delta^{-}$denote the reduction in the stock of labor, we obtain the first order condition for $\Delta^{-}$as

$$
\theta f^{\prime}\left(\ell_{1}+\Delta^{-}\right)=W-C
$$


or

$$
\ell_{1}+\Delta^{-}=\left(f^{\prime}\right)^{-1}\left(\frac{W-C}{\theta}\right)
$$

Take $\ell_{1}$ as given. Observe that if $0<\theta<\theta^{*}, \Delta<0$. Define $\varphi \equiv f^{\prime-1}$. Observe that from concavity $\varphi^{\prime}<0$. Then

$$
\ell_{1}+\Delta^{-}=\varphi\left(\frac{W-C}{\theta}\right)
$$

Observe that at $\theta=\theta^{*}, \Delta^{-}=0$. If $\theta>\bar{\theta}, \theta f^{\prime}\left(\ell_{1}+\Delta^{+}\right)=W$ and $\left(\ell_{1}+\Delta^{+}\right)=\varphi\left(\frac{W}{\theta}\right)$. If $\theta^{*}<\theta<\bar{\theta}$, the firm operates at $\ell_{1}$ and $\Delta=0$. If $\theta<\theta^{*}, \theta f^{\prime}\left(\ell_{1}+\Delta^{-}\right)=W-C$ and $\ell_{1}+\Delta^{-}=\varphi\left(\frac{W-C}{\theta}\right)$. Define $g(\theta)$ as the density of $\theta$. Given $\ell_{1}$, expected demand in period 2 (averaged over the $\theta$ states) is, for a given firm,

$$
E\left(\ell_{2} \mid W, C, \ell_{1}\right)=\int_{0}^{\theta^{*}} \varphi\left(\frac{W-C}{\theta}\right) g(\theta) d \theta+\ell_{1} \int_{\theta^{*}}^{\bar{\theta}} g(\theta) d \theta+\int_{\bar{\theta}}^{\infty} \varphi\left(\frac{W}{\theta}\right) g(\theta) d \theta
$$

Thus

$$
\begin{aligned}
\frac{\partial E\left(\ell_{2} \mid W, C, \ell_{1}\right)}{\partial W}= & \frac{\partial \theta^{*}}{\partial W} \varphi\left(\frac{W-C}{\theta^{*}}\right) g\left(\theta^{*}\right)+\int_{0}^{\theta^{*}} \frac{1}{\theta} \varphi^{\prime}\left(\frac{W-C}{\theta^{*}}\right) g(\theta) d \theta+\int_{\bar{\theta}}^{\infty}\left(\frac{1}{\theta}\right) \varphi^{\prime}\left(\frac{W}{\theta}\right) g(\theta) d \theta \\
& +\ell_{1}\left[\frac{\partial \bar{\theta}}{\partial W} g(\bar{\theta})-\frac{\partial \theta^{*}}{\partial W} g\left(\theta^{*}\right)\right]-\left(\frac{\partial \bar{\theta}}{\partial W}\right) \varphi\left(\frac{W}{\bar{\theta}}\right) g(\bar{\theta}), \\
\frac{\partial E\left(\ell_{2} \mid W, C, \ell_{1}\right)}{\partial C}= & \left(\frac{\partial \theta^{*}}{\partial C}\right) \varphi\left(\frac{W-C}{\theta^{*}}\right) g\left(\theta^{*}\right)-\int_{0}^{\theta^{*}} \frac{1}{\theta} \varphi^{\prime}\left(\frac{W-C}{\theta}\right) g(\theta) d \theta \\
& +\ell_{1}\left[\frac{\partial \bar{\theta}}{\partial C} g(\bar{\theta})-\frac{\partial \theta^{*}}{\partial C} g\left(\theta^{*}\right)\right]-\frac{\partial \bar{\theta}}{\partial C} \varphi\left(\frac{W}{\bar{\theta}}\right) g(\bar{\theta}) .
\end{aligned}
$$

Using the demand function, $\varphi\left(\frac{W-C}{\theta^{*}}\right)=\ell_{1}$ and $\varphi\left(\frac{W}{\bar{\theta}}\right)=\ell_{1}$

$$
\frac{\partial E\left(\ell_{2} \mid W, C, \ell_{1}\right)}{\partial W}=\int_{0}^{\theta^{*}} \frac{1}{\theta} \varphi^{\prime}\left(\frac{W-C}{\theta}\right) g(\theta) d \theta+\int_{\bar{\theta}}^{\infty} \frac{1}{\theta} \varphi^{\prime}\left(\frac{W}{\theta}\right) g(\theta) d \theta<0
$$

and

$$
\frac{\partial E\left(\ell_{2} \mid W, C, \ell_{1}\right)}{\partial C}=-\int_{0}^{\theta^{*}} \frac{1}{\theta} \varphi^{\prime}\left(\frac{W}{\theta}\right) g(\theta) d \theta>0
$$


The positivity of this final expression arises from the fact that as $C$ increases, the firm is more risk averse $\left(\theta^{*}\right.$ falls $)$ so that it is more likely that it hires labor in the second period.

If $\theta$ is iid across firms in period 2, and iid across time, then the mean conditional (on $\ell_{1}$ ) labor demand function is not a direct function of $W+\operatorname{Pr}\left(0<\theta<\theta^{*}\right) C$ which, in this simple framework, is the measure of labor cost used in Heckman and Pagés (2000) and in the empirical analysis of Section 5. In fact, the model predicts that

$$
\frac{\partial E\left(\ell_{2} \mid W, C, \ell_{1}\right)}{\partial W}+\frac{\partial E\left(\ell_{2} \mid W, C, \ell_{1}\right)}{\partial C}<0
$$

so that $\frac{\partial E\left(\ell_{2} \mid W, C, \ell_{1}\right)}{\partial W}$ is larger in absolute value than $\frac{\partial E\left(\ell_{2} \mid W, C, \ell_{1}\right)}{\partial C}$ although they are of opposite signs.

This analysis suggests that empirical specifications of labor demand functions should use $C$ and $W$ separately. $W$ corresponds to static costs as defined in the text. $C$ corresponds to costs of adjustment. OLS regressions of conditional (on $\ell_{1}$ ) demand functions do not identify the standard substitution terms used in static demand analysis.

One way to avoid problems with direct estimation of labor demand functions is to estimate production functions. These can be used to derive the demand functions given fixed costs without directly estimating demand functions with fixed costs.

\section{First Period Demand Functions}

These are obtained by substituting each state-contingent $\ell_{2}=\ell_{1}+\Delta$ demand function into (B-1) and maximizing with respect to $\ell_{1}$. As in the analysis of the second period demand function, $W+\operatorname{Pr}\left(0<\theta<\theta^{*}\right) C$ is not an appropriate marginal price in any state. Substituting into (B-1), and making the dependence of $\Delta^{-}$and $\Delta^{+}$on $W, C, \ell_{1}$ explicit, we obtain total profits (as perceived in the first period) as 


$$
\begin{aligned}
f\left(\ell_{1}\right)-W \ell_{1} & +\int_{0}^{\theta^{*}}\left[\theta f\left(\ell_{1}+\Delta^{-}\left(W, C, \ell_{1}, \theta\right)\right)-(W-C) \Delta^{-}\left(W, C, \ell_{1}\right)-W \ell_{1}\right] g(\theta) d \theta \\
& +\int_{\theta^{*}}^{\bar{\theta}}\left[\theta f\left(\ell_{1}\right)-W \ell_{1}\right] g(\theta) d \theta \\
& +\int_{\bar{\theta}}^{\infty}\left[\theta f \left(\ell_{1}+\Delta^{+}\left(W, C, \ell_{1}\right)-W\left(\ell_{1}+\Delta^{+}\left(W, C, \ell_{1}\right)\right] g(\theta) d \theta .\right.\right.
\end{aligned}
$$

Assuming an interior solution, and using the envelope theorem,

$$
f^{\prime}\left(\ell_{1}\right)-W+\int_{0}^{\theta^{*}}\left[\theta f^{\prime}\left(\ell_{1}+\Delta^{-}\left(W, C, \ell_{1}, \theta\right)\right)-W\right] g(\theta) d \theta+\int_{\theta^{*}}^{\bar{\theta}}\left[\theta f^{\prime}\left(\ell_{1}\right)-W\right] g(\theta) d \theta=0
$$

so the first period demand obtained as the solution to this equation $\ell$ is a function of $W$ and $C$ separately and not $W+\operatorname{Pr}\left(0<\theta \leq \theta^{*}\right) C$. Observe, trivially, that the $\ell_{1}$ obtained as a solution of this first order condition is lower than the $\ell_{1}$ obtained when $C=0$. This rationalizes our choice of $\bar{\theta}<1$ in the heuristic solution outlined above. 
Table 1 Latin American \& Caribbean Economic Performance Indicators

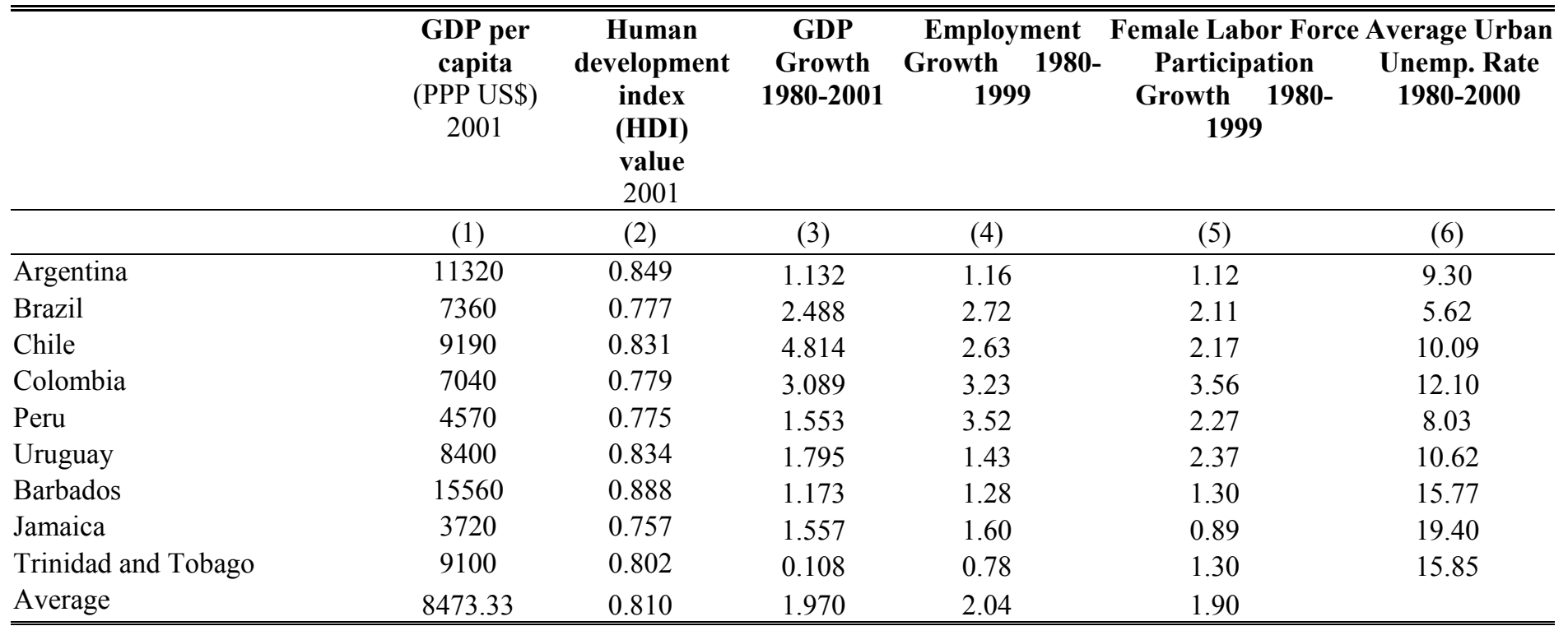

Notes: (3) measured in local currency at constant prices; (6) Caribbean rates are not comparable to LA rates because they are computed with a different methodology;

Sources: (1), (3) and (5) World Development Indicators (World Bank CD-ROM, 2000), The World Bank; (2) United Nations; (4) and (6) ECLAC and ILO. 


\begin{tabular}{lccc}
\hline \hline & $\begin{array}{c}\text { \% of workers affiliated with } \\
\text { mandatory Social Security programs }\end{array}$ & $\begin{array}{c}\text { \% of workers 25-40 } \\
\text { years old with net } \\
\text { earnings below } \\
\text { Minimum Wage }\end{array}$ \\
\hline Country & $\begin{array}{c}\text { \% of Total } \\
\text { Employment }\end{array}$ & $\begin{array}{c}\text { \% of Wage } \\
\text { Employment }\end{array}$ & $\begin{array}{c}\text { Non Compliance } \\
\text { with Minimum } \\
\text { wages }\end{array}$ \\
\hline Average Latin America (*) & Mean 1990s & Mean 1990s & End 1990s \\
\hline Argentina & 39.35 & 60.05 & 10.06 \\
Bolivia (1999) & 48.45 & 66.56 & 3.11 \\
Brazil & 26.36 & 38.56 & 1.11 \\
Chile & 48.18 & 64.04 & 5.80 \\
Colombia (1999) & 64.47 & 77.45 & 7.3 \\
Costa Rica & 46.13 & 66.77 & 26.9 \\
Dominican Republic (1998) & 65.92 & 74.61 & 15.7 \\
Ecuador (1995) & 29.08 & 49.40 & NA \\
El Salvador (1998) & 30.94 & 43.02 & NA \\
Mexico & 33.49 & 50.04 & 3.6 \\
Panama (2001) & 52.53 & 67.96 & 0.5 \\
Paraguay (1995) & 55.66 & 74.50 & 14.8 \\
Peru & 16.70 & 30.66 & NA \\
Uruguay & 17.99 & 51.90 & 23.5 \\
Venezuela (1998) & 74.12 & 93.12 & 0.5 \\
\hline \hline Not & 31.37 & 52.22 & 17.9 \\
\hline
\end{tabular}

Notes: $\left(^{*}\right)$ Unweighted Average. Percentage of workers between 15 and 64 that are affiliated to social security. Time series data for the nineties is incomplete, the mean and trend were computed when data included 3 or more years, spread over 3 periods: early (1990-93), mid (1994-97) and late (1998-01). Non Compliance with Minimum Wage refers to employees between 25 and 40 years old working more than 30 hours. Figures for this variable date from the late nineties. Source: IADB (2003) based on individual country household surveys 
Table 3: Measures of Labor Market Regulations. End of the 1990's

\begin{tabular}{|c|c|c|c|c|c|c|c|c|}
\hline Country & Year & $\begin{array}{l}\text { Advance } \\
\text { Notice } \\
\text { (EPV) }\end{array}$ & $\begin{array}{l}\text { Indemnities } \\
\text { for dismissal } \\
\text { (EPV) }\end{array}$ & $\begin{array}{l}\text { Seniority } \\
\text { Pay } \\
\text { (EPV) }\end{array}$ & $\begin{array}{l}\text { Social Security } \\
\text { Contributions } \\
\text { (EPV) }\end{array}$ & $\begin{array}{c}\text { Total Cost } \\
\text { (EPV) }\end{array}$ & $\begin{array}{c}\text { Social Security } \\
\text { Contributions as } \\
\% \text { of Total } \\
\text { Costs }\end{array}$ & $\begin{array}{l}\text { Social Security } \\
\text { Contributions } \\
\text { (\% Wage) }\end{array}$ \\
\hline & & (1) & (2) & (3) & (4) & $(1)+(2)+(3)+(4)$ & & \\
\hline Australia & 1999 & 0.73 & 0.99 & 0.00 & 1.95 & 3.67 & $53.04 \%$ & 0.02 \\
\hline Austria & 1999 & 0.85 & 0.94 & 0.00 & 58.29 & 60.07 & $97.03 \%$ & 0.45 \\
\hline Belgium & 1999 & 1.73 & 0.00 & 0.00 & 40.17 & 41.89 & $95.87 \%$ & 0.31 \\
\hline Canada & 1999 & 0.60 & 0.19 & 0.00 & 18.56 & 19.35 & $95.93 \%$ & 0.14 \\
\hline Denmark & 1999 & 1.73 & 0.04 & 0.00 & NA & 1.77 & & \\
\hline Finland & 1999 & 1.61 & 0.00 & 0.00 & 35.62 & 37.23 & $95.67 \%$ & 0.27 \\
\hline France & 1999 & 0.98 & 0.36 & 0.00 & 64.77 & 66.11 & $97.97 \%$ & 0.50 \\
\hline Germany & 1999 & 1.14 & 0.00 & 0.00 & 53.48 & 54.63 & $97.91 \%$ & 0.41 \\
\hline Greece & 1999 & 0.00 & 1.34 & 0.00 & 46.54 & 47.88 & $97.20 \%$ & 0.36 \\
\hline Hungary & 1999 & 0.87 & 0.73 & 0.00 & 65.56 & 67.15 & $97.63 \%$ & 0.51 \\
\hline Ireland & 1999 & 0.45 & 0.58 & 0.00 & 24.67 & 25.70 & $95.99 \%$ & 0.19 \\
\hline Italy & 1999 & 0.60 & 2.63 & 0.00 & 91.53 & 94.76 & $96.60 \%$ & 0.71 \\
\hline Japan & 1999 & 0.59 & 0.00 & 0.00 & 36.36 & 36.95 & $98.40 \%$ & 0.28 \\
\hline Korea & 1999 & 0.59 & 2.99 & 0.00 & 18.08 & 21.66 & $83.49 \%$ & 0.14 \\
\hline Netherlands & 1999 & 0.88 & 0.00 & 0.00 & 84.99 & 85.87 & $98.97 \%$ & 0.65 \\
\hline New Zealand & 1999 & 0.22 & 0.00 & 0.00 & 0.00 & 0.22 & $0.00 \%$ & 0.00 \\
\hline Norway & 1999 & 0.88 & 0.00 & 0.00 & 28.43 & 29.31 & $97.00 \%$ & 0.22 \\
\hline Poland & 1999 & 1.22 & 0.00 & 0.00 & 60.48 & 61.70 & $98.02 \%$ & 0.47 \\
\hline Portugal & 1999 & 1.18 & 3.30 & 0.00 & 49.01 & 53.49 & $91.63 \%$ & 0.38 \\
\hline Spain & 1999 & 0.59 & 2.58 & 0.00 & 49.43 & 52.60 & $93.98 \%$ & 0.38 \\
\hline Sweden & 1999 & 1.79 & 0.00 & 0.00 & 28.86 & 30.65 & $94.16 \%$ & 0.22 \\
\hline Switzerland & 1999 & 1.25 & 0.00 & 0.00 & 19.26 & 20.51 & $93.92 \%$ & 0.15 \\
\hline Turkey & 1999 & 0.99 & 2.99 & 0.00 & 44.79 & 48.76 & $91.85 \%$ & 0.35 \\
\hline United Kingdom & 1999 & 0.71 & 0.72 & 0.00 & 28.82 & 30.25 & $95.27 \%$ & 0.22 \\
\hline United States & 1999 & 0.00 & 0.00 & 0.00 & 23.56 & 23.56 & $100.00 \%$ & 0.18 \\
\hline Average OECD & 1999 & 0.89 & 0.82 & 0.00 & 40.55 & 42.25 & $95.97 \%$ & 0.31 \\
\hline Argentina & 1999 & 0.80 & 2.20 & 0.00 & 44.49 & 47.48 & $93.69 \%$ & 0.34 \\
\hline Bolivia & 1999 & 1.77 & 2.99 & 0.00 & 31.16 & 35.91 & $86.76 \%$ & 0.24 \\
\hline Brazil & 1999 & 0.59 & 2.45 & 9.82 & 37.65 & 50.51 & $74.53 \%$ & 0.29 \\
\hline Chile & 1999 & 0.59 & 2.79 & 0.00 & 27.20 & 30.58 & $88.95 \%$ & 0.21 \\
\hline Colombia & 1999 & 0.30 & 3.49 & 9.82 & 38.75 & 52.35 & $74.01 \%$ & 0.30 \\
\hline Costa Rica & 1999 & 1.05 & 2.60 & 0.00 & 35.05 & 38.69 & $90.58 \%$ & 0.27 \\
\hline Dominican Rep. & 1999 & 0.59 & 2.16 & 0.00 & 16.23 & 18.97 & $85.52 \%$ & 0.13 \\
\hline Ecuador & 1999 & 0.59 & 3.30 & 9.82 & 22.85 & 36.56 & $62.50 \%$ & 0.18 \\
\hline El Salvador & 1999 & 0.06 & 2.99 & 0.00 & 27.26 & 30.31 & $89.94 \%$ & 0.21 \\
\hline Honduras & 1999 & 0.59 & 2.94 & 0.00 & 13.63 & 17.16 & $79.43 \%$ & 0.11 \\
\hline Jamaica & 1999 & 0.59 & 1.41 & 0.00 & 6.49 & 8.49 & $76.47 \%$ & 0.05 \\
\hline Mexico & 1999 & 0.59 & 2.57 & 0.00 & 29.50 & 32.66 & $90.33 \%$ & 0.23 \\
\hline Nicaragua & 1999 & 0.59 & 1.97 & 0.00 & 19.47 & 22.04 & $88.37 \%$ & 0.15 \\
\hline Panama & 1999 & 0.59 & 2.09 & 0.75 & 15.19 & 18.62 & $81.58 \%$ & 0.12 \\
\hline Paraguay & 1999 & 0.68 & 1.49 & 0.00 & 27.26 & 29.43 & $92.63 \%$ & 0.21 \\
\hline Peru & 1999 & 0.00 & 3.80 & 9.82 & 27.26 & 40.88 & $66.69 \%$ & 0.21 \\
\hline Trinidad \& Tobago & 1999 & 1.18 & 1.33 & 0.00 & 10.90 & 13.41 & $81.31 \%$ & 0.08 \\
\hline Uruguay & 1999 & 0.00 & 2.23 & 0.00 & 52.58 & 54.81 & $95.93 \%$ & 0.41 \\
\hline Venezuela & 1999 & 0.93 & 2.03 & 5.97 & 18.43 & 27.36 & $67.37 \%$ & 0.14 \\
\hline Avg. Latin America & & 0.63 & 2.46 & 2.42 & 26.39 & 31.91 & $82.45 \%$ & 0.20 \\
\hline
\end{tabular}

Source: Authors' calculations based on OECD (1999), Grubbs and Wells (1993), US Social Security Administration and Ministries of Labor in Latin America and the Caribbean. EPV denotes Expected Present Discounted Value 
Table 4: Estimates of long-run constant-output labor demand elasticity

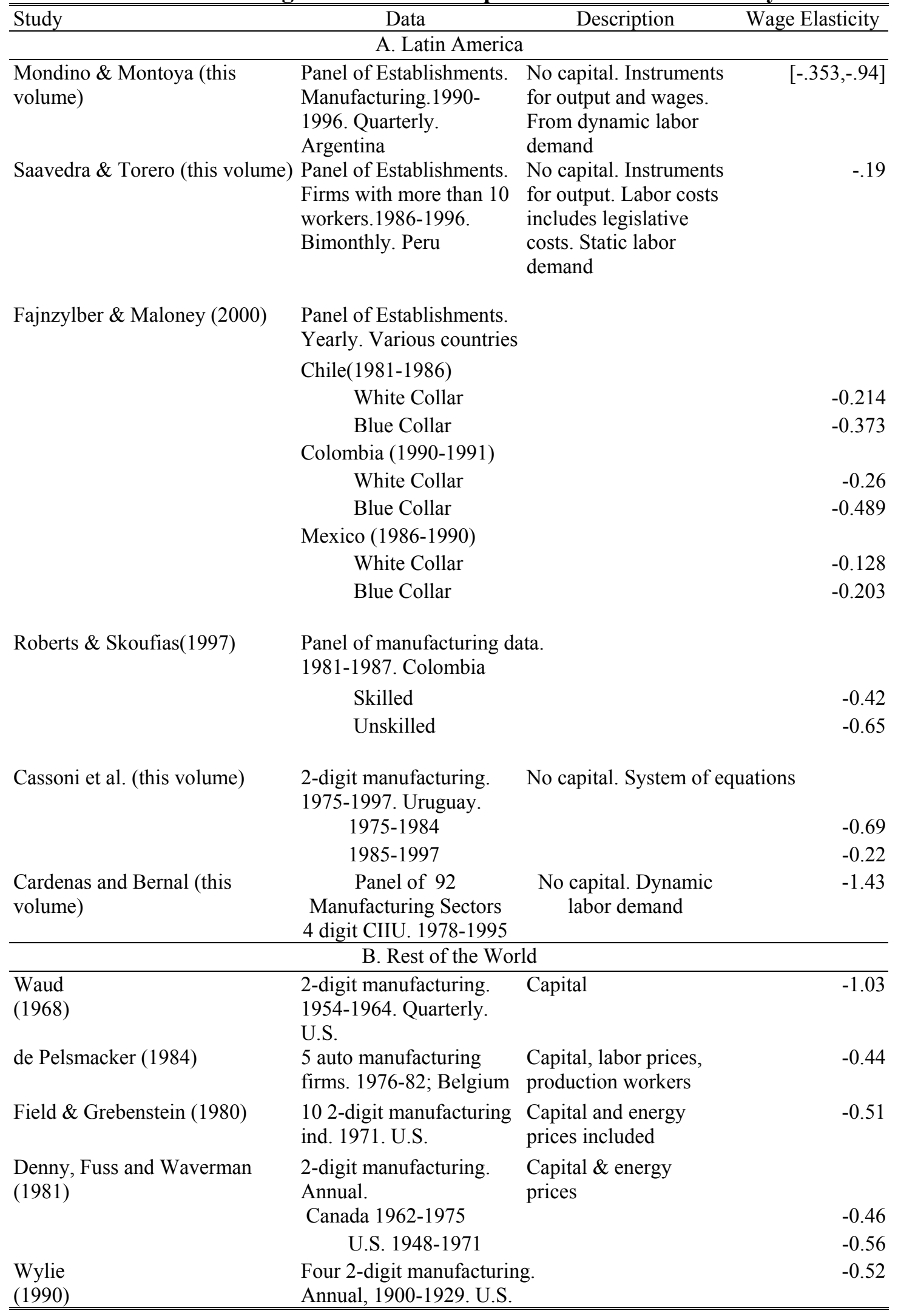




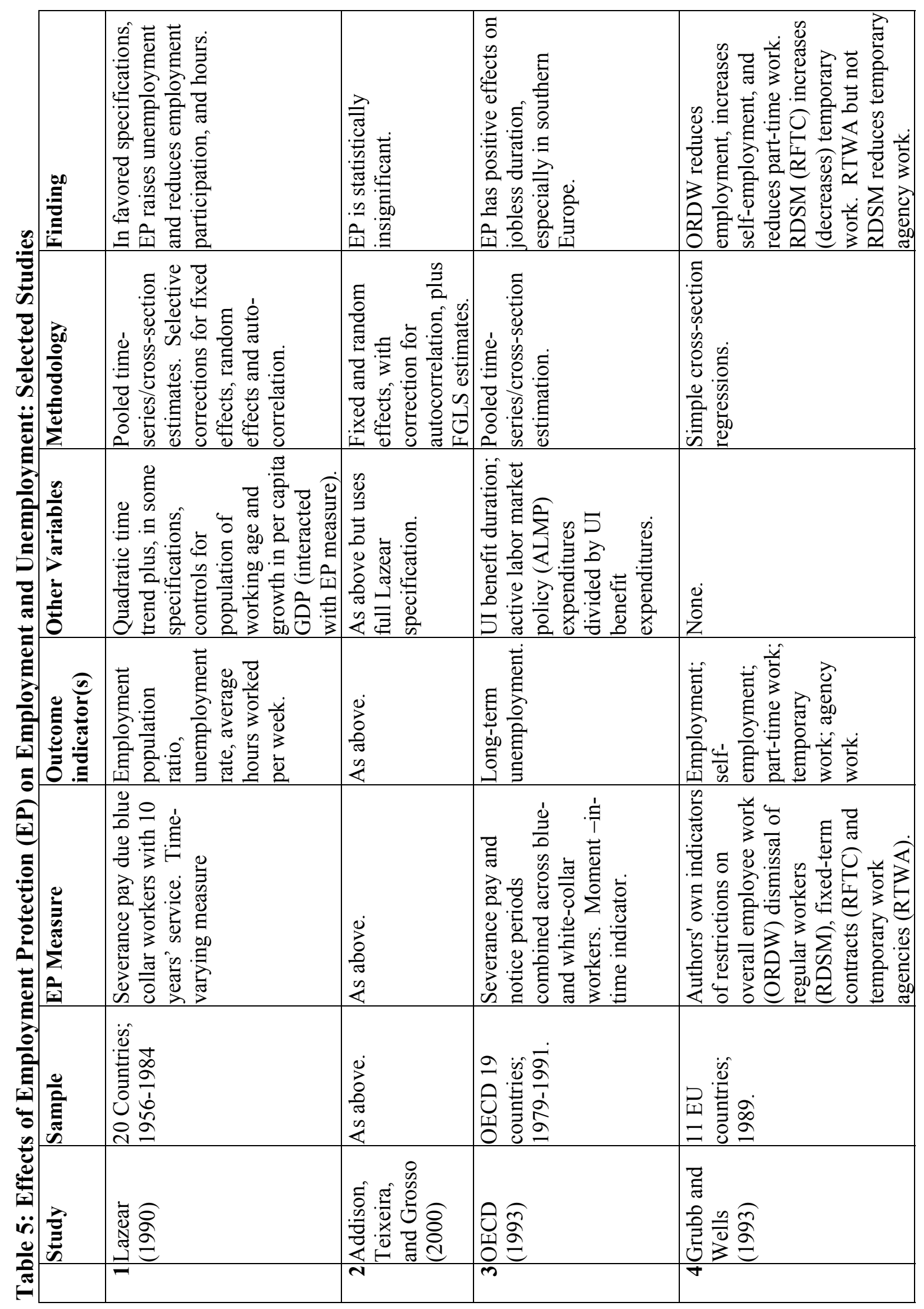




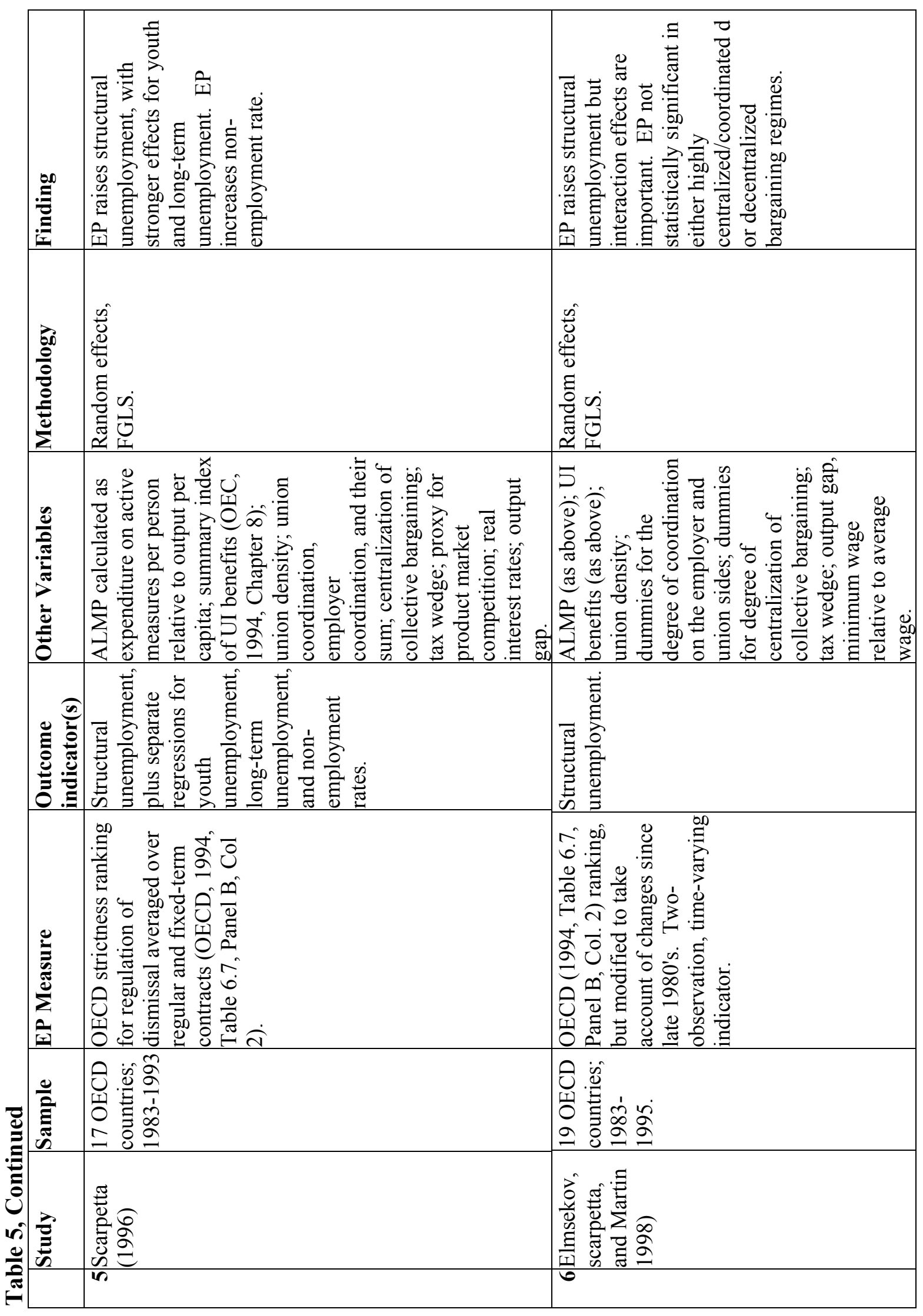




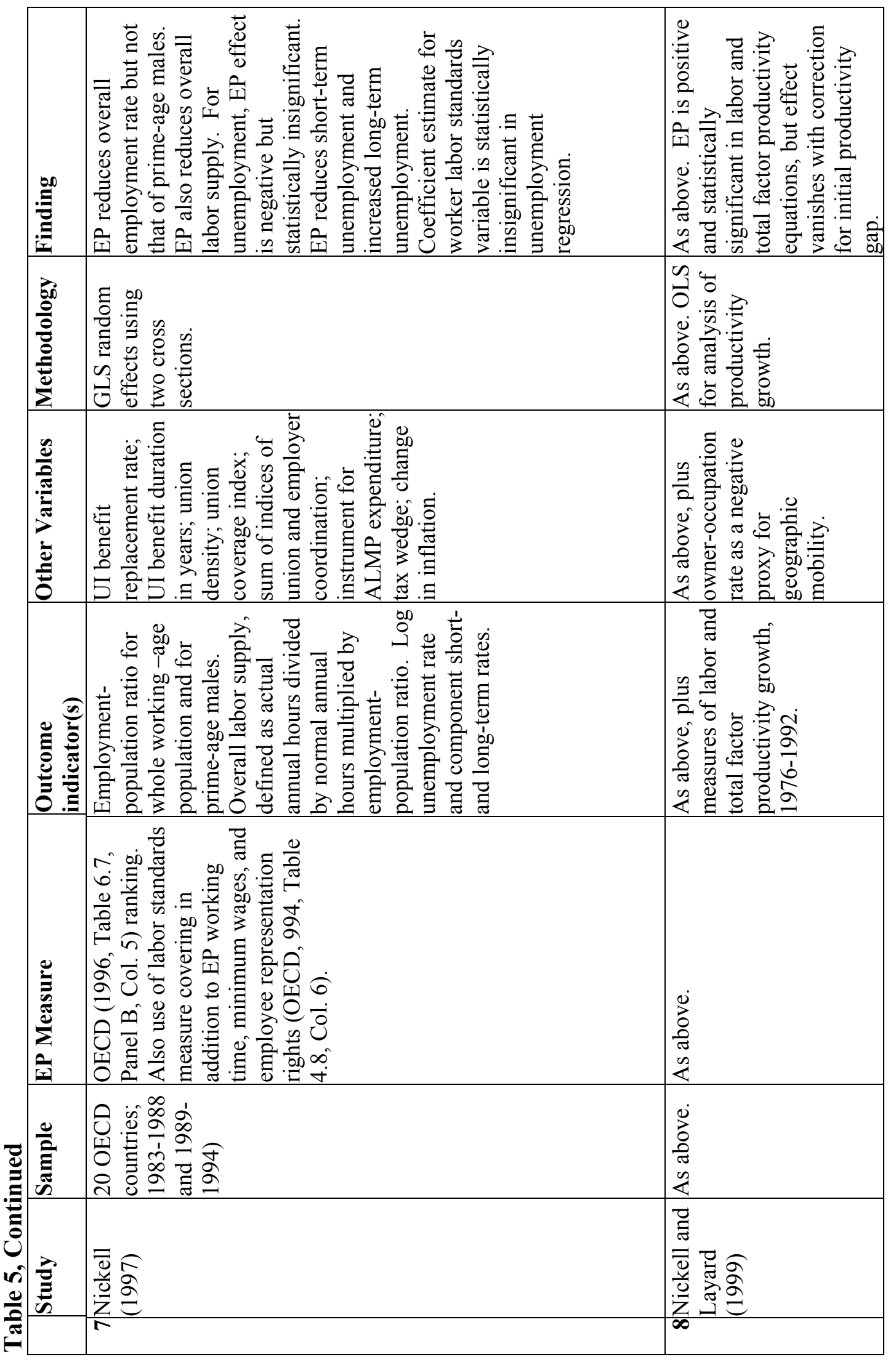




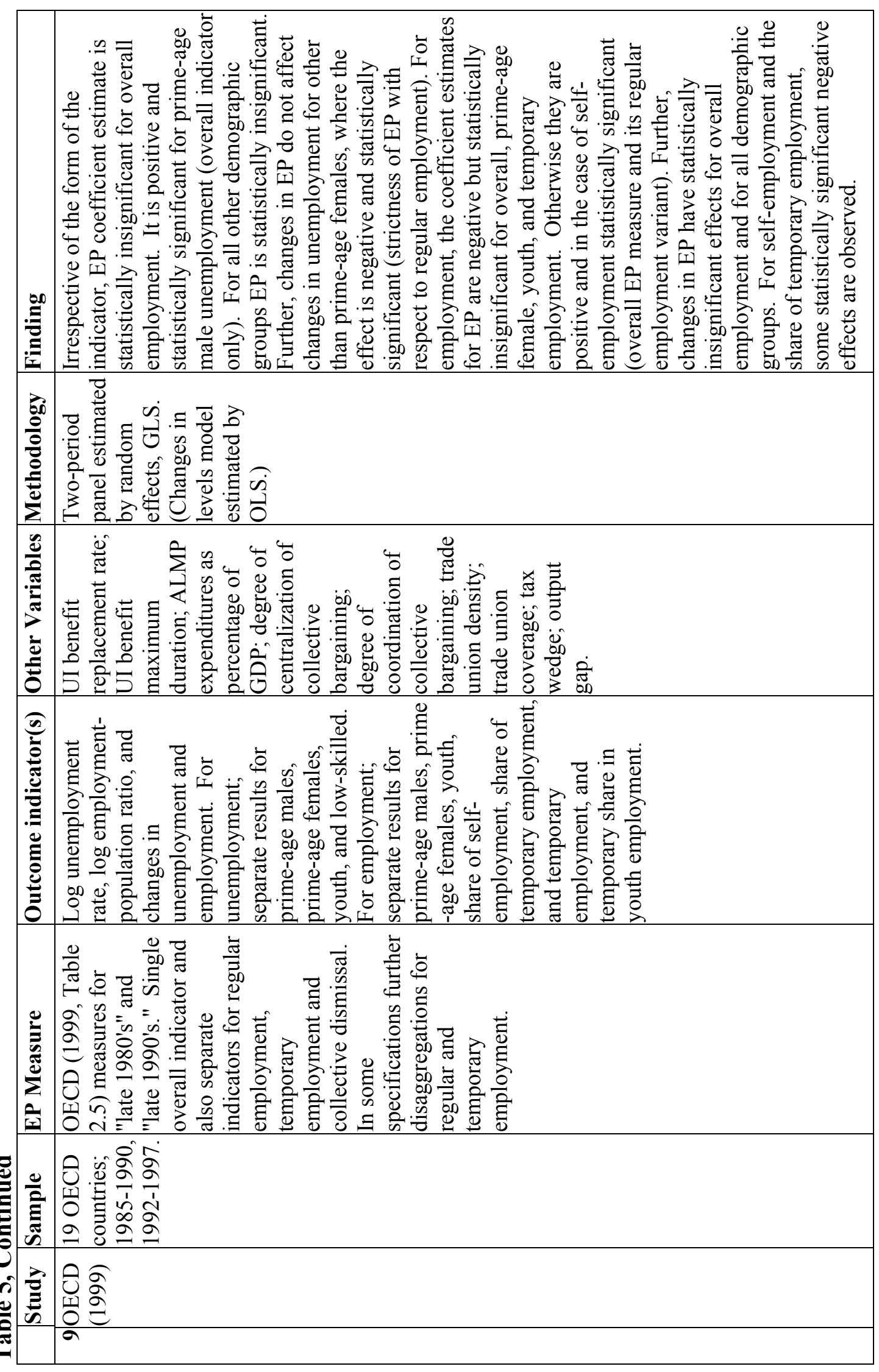




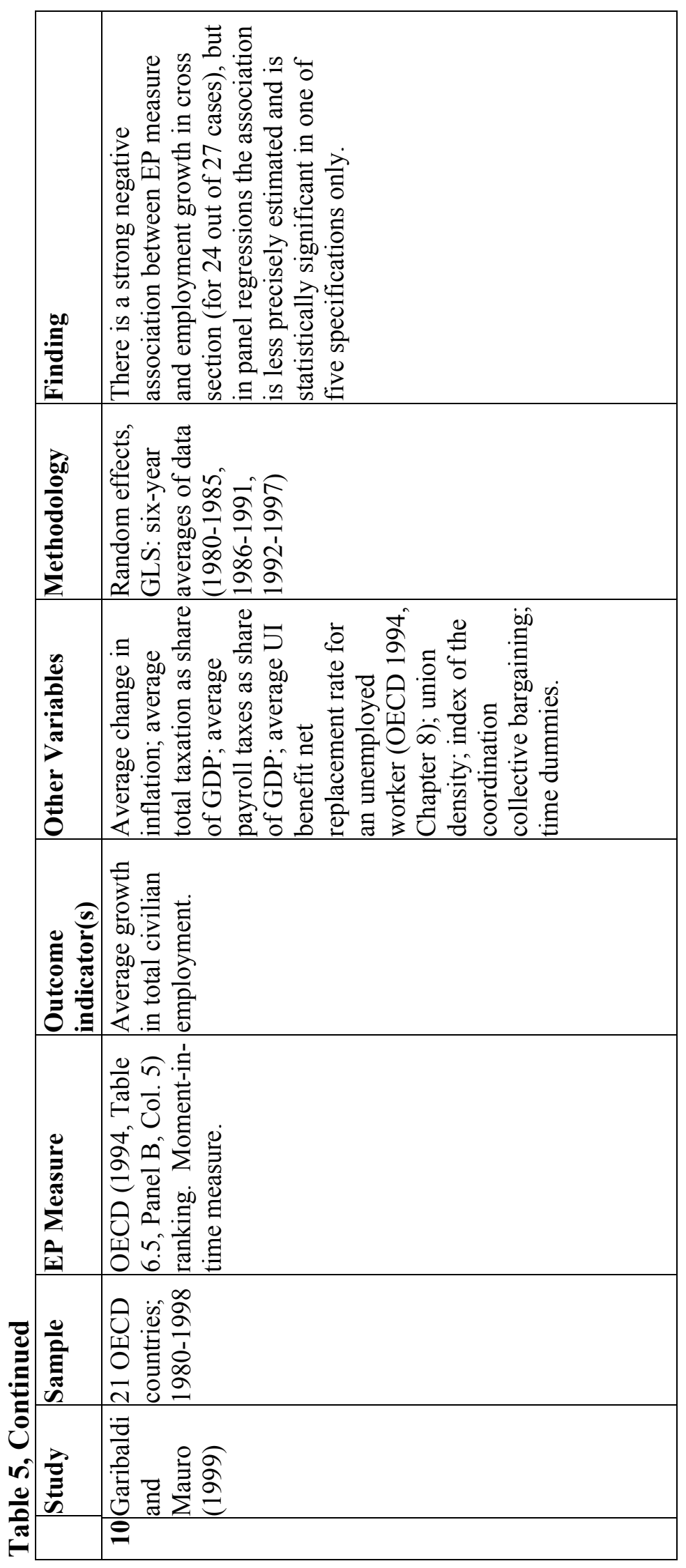




\begin{tabular}{|c|c|}
\hline 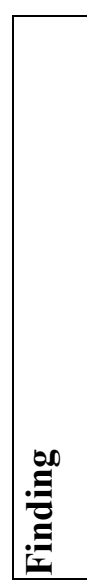 & 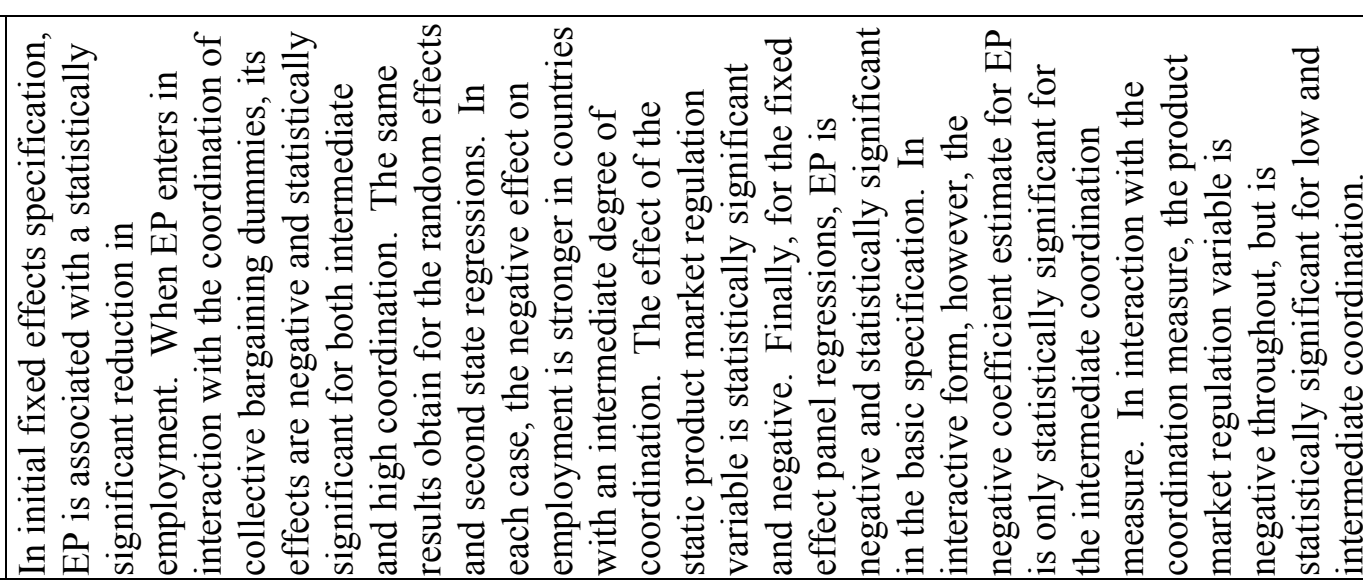 \\
\hline$\frac{1}{20}$ & 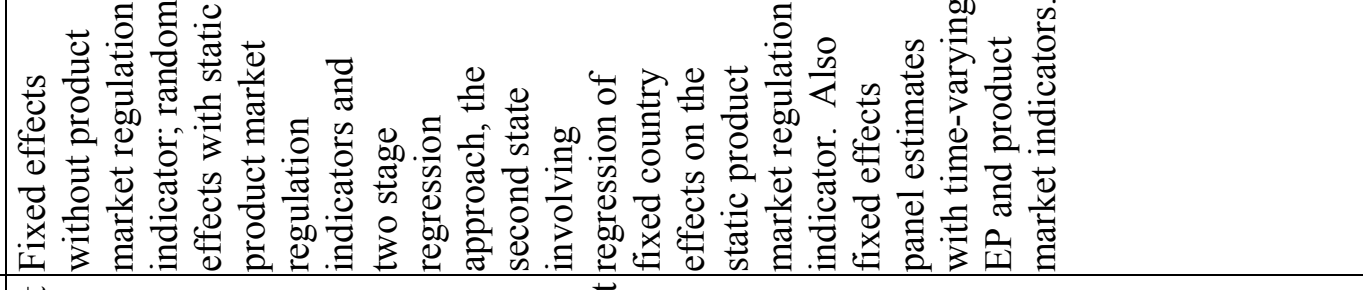 \\
\hline 产 & 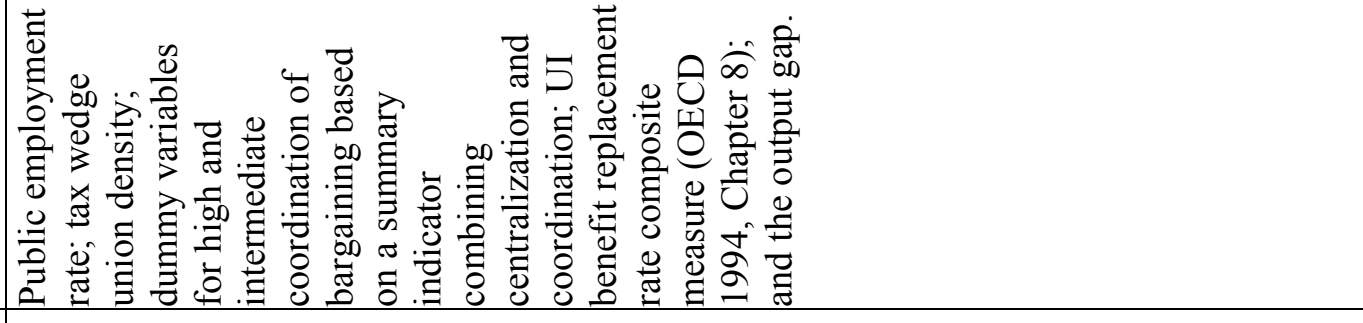 \\
\hline & 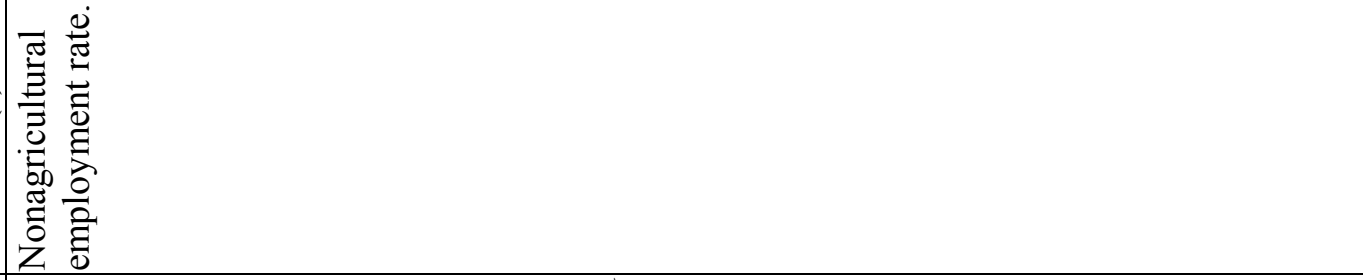 \\
\hline & 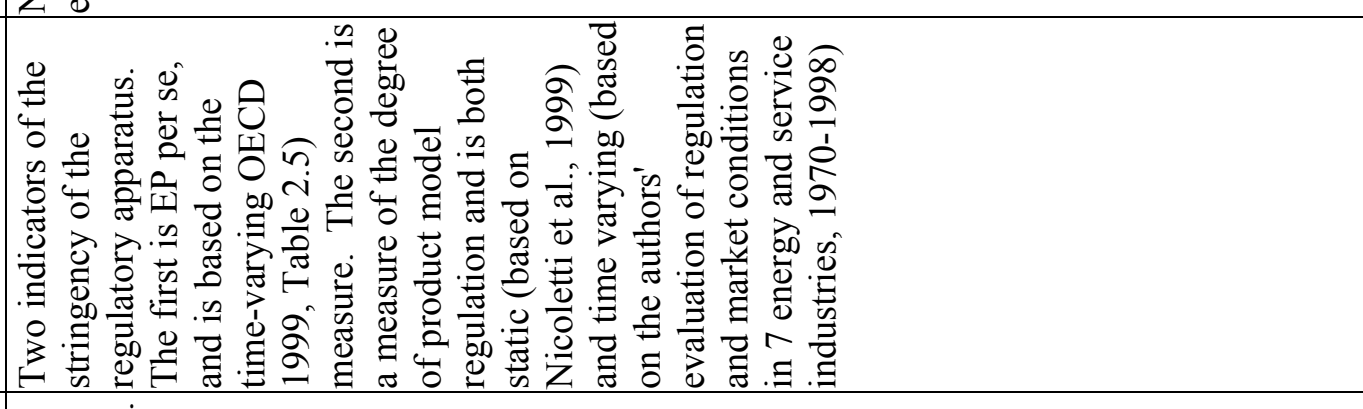 \\
\hline & 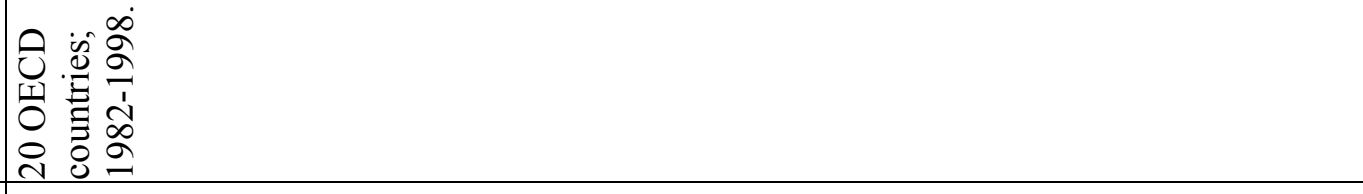 \\
\hline 䆖 & 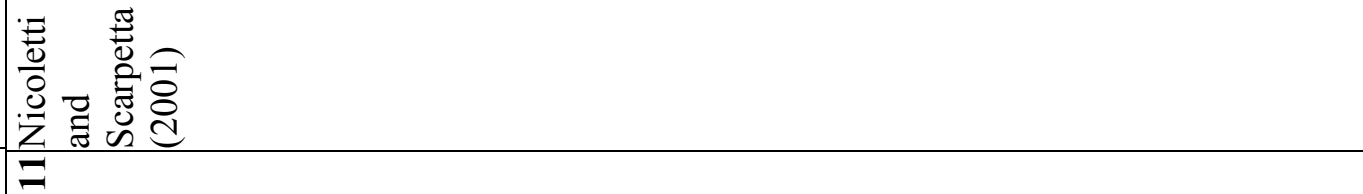 \\
\hline
\end{tabular}




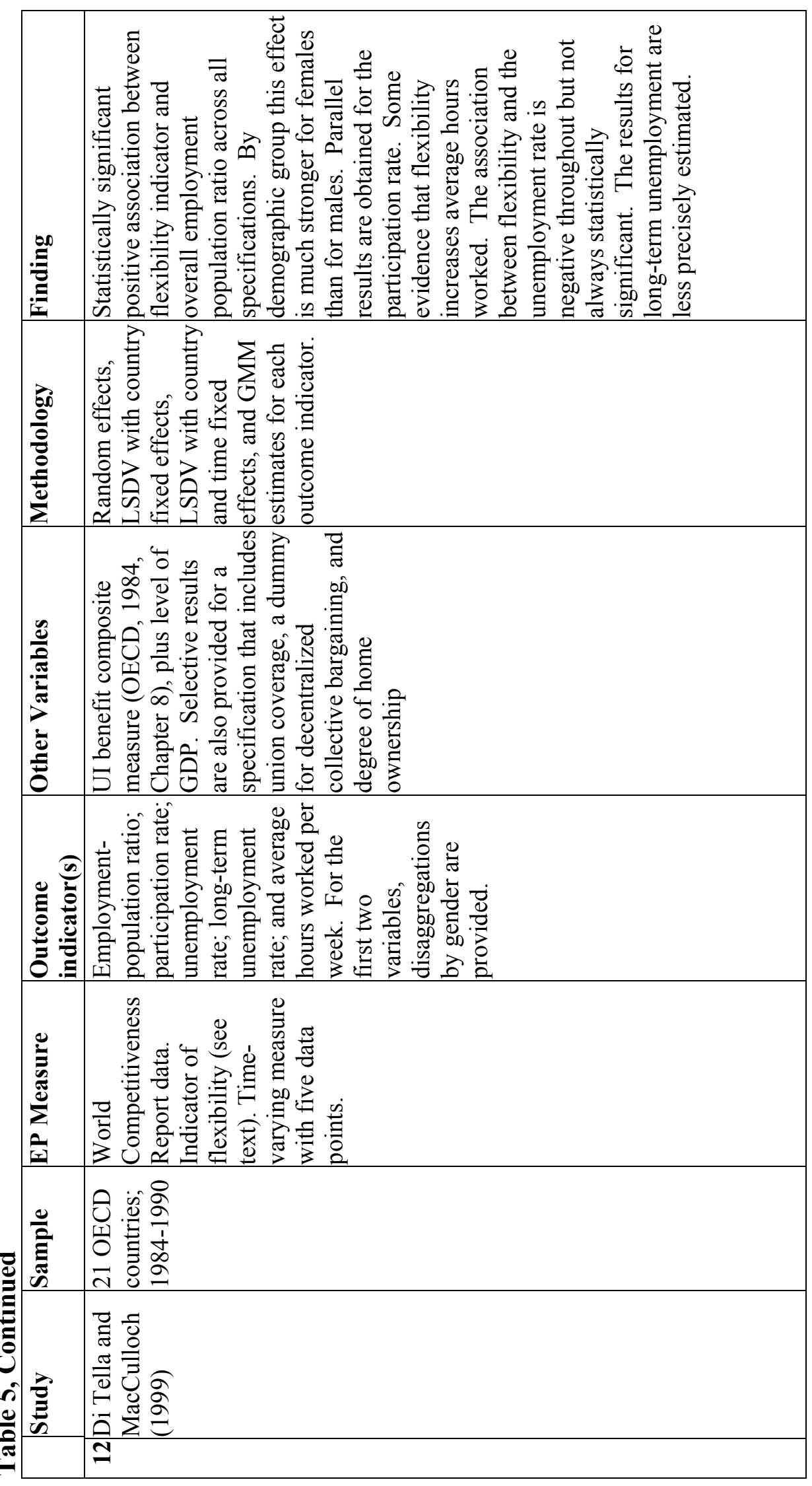




\begin{tabular}{|c|c|}
\hline : & 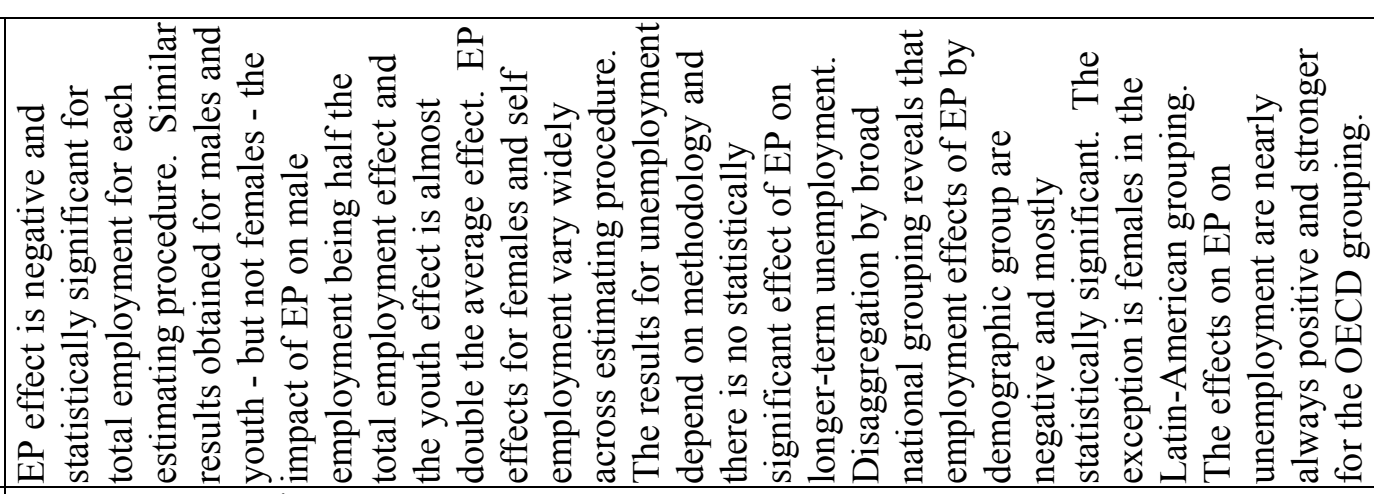 \\
\hline & 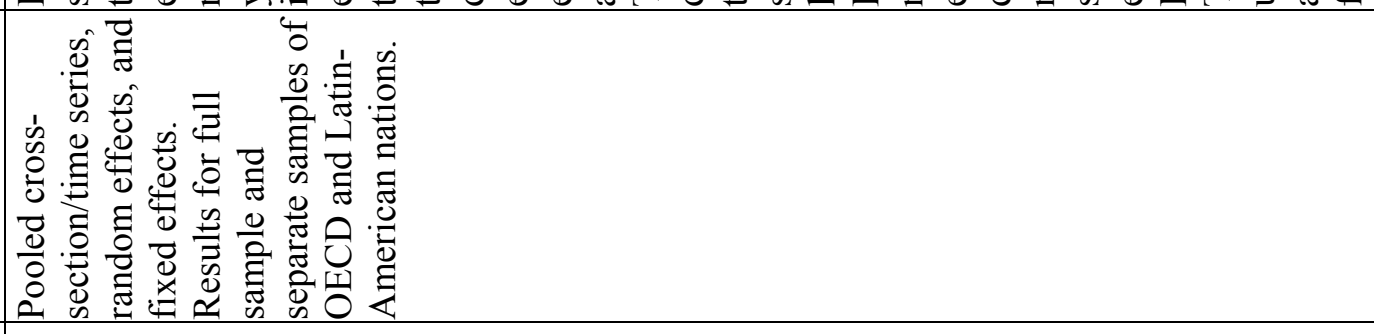 \\
\hline 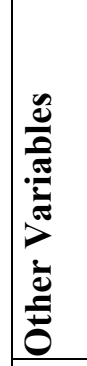 & 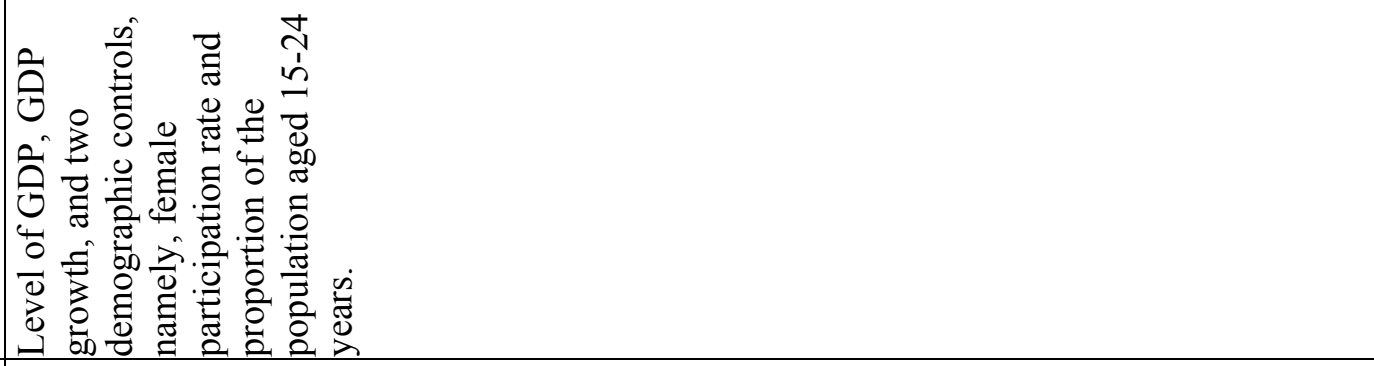 \\
\hline & 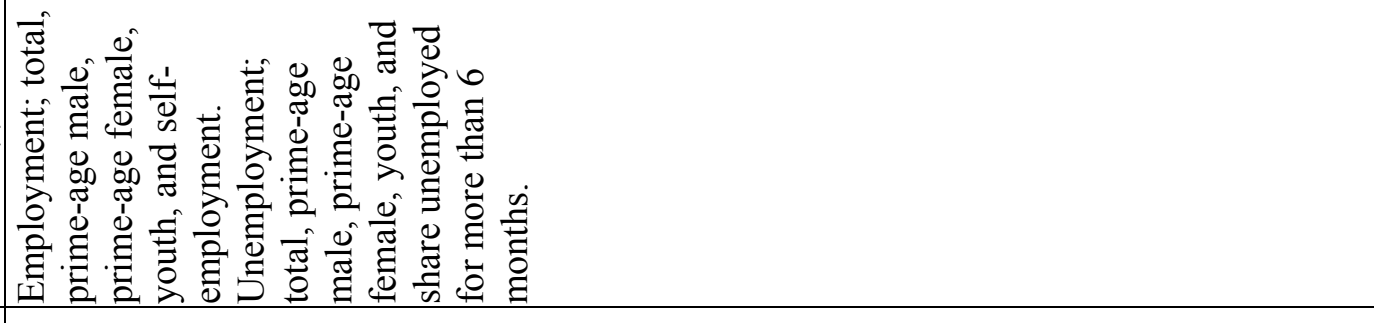 \\
\hline & 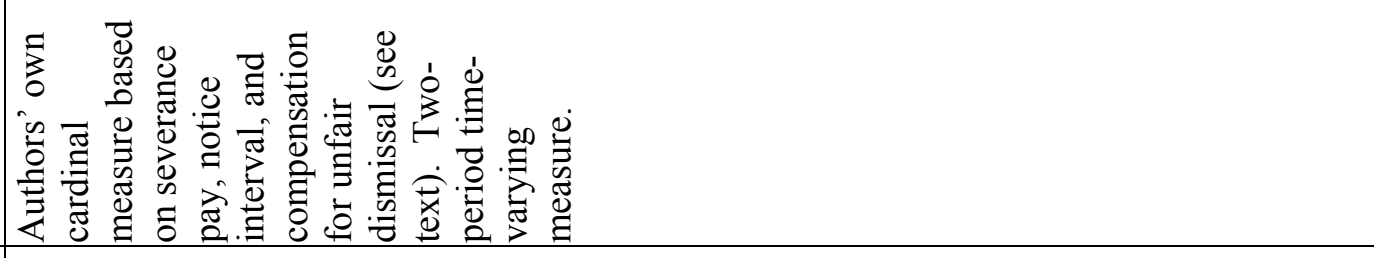 \\
\hline 产 & 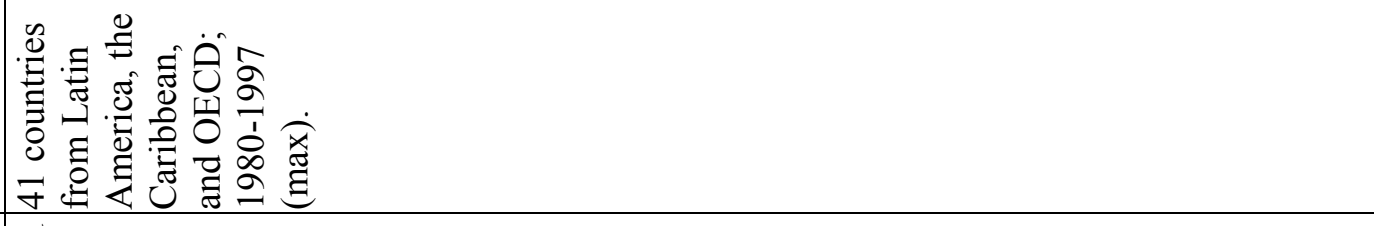 \\
\hline 焉 & 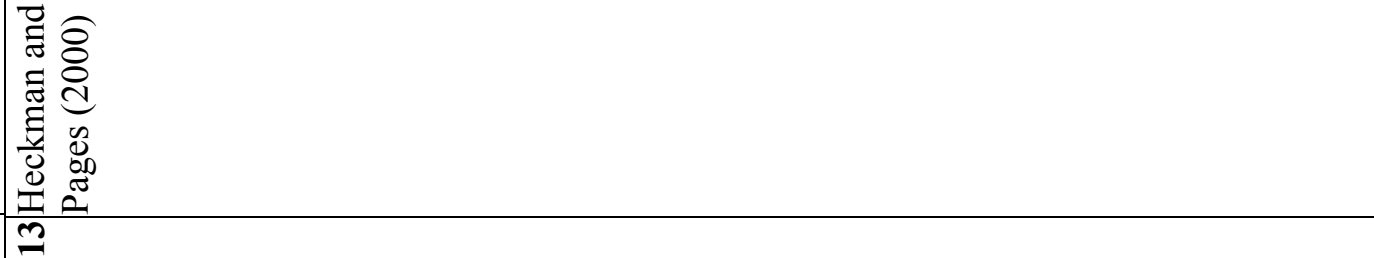 \\
\hline
\end{tabular}




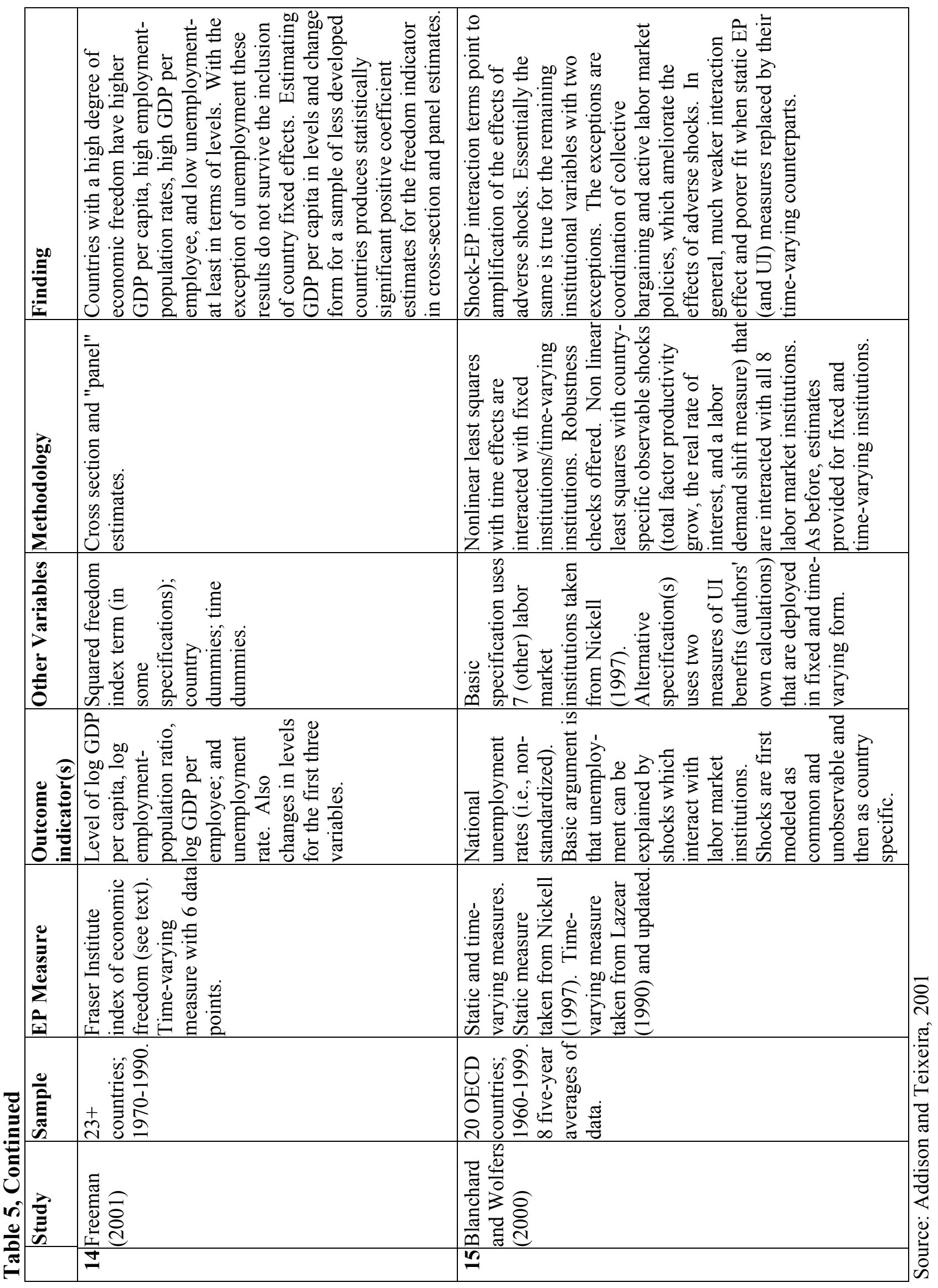


Table 6: Summary of existing evidence on the impact of job security (JS) costs

in Latin America

\begin{tabular}{|c|c|c|c|}
\hline Study & Country & Data & Results \\
\hline \multicolumn{4}{|c|}{ A. Studies that analyze exit rates into and out of employment } \\
\hline $\begin{array}{l}\text { Kugler } \\
\text { (This volume) }\end{array}$ & Colombia & Household data & $\begin{array}{l}\text { Decline in JS leads to reduction in employment duration, reduction in } \\
\text { unemployment duration. Some effect due to de-regulation of temporary } \\
\text { contracts but not all }\end{array}$ \\
\hline $\begin{array}{l}\text { Saavaedra and } \\
\text { Torero } \\
\text { (This volume) }\end{array}$ & Peru & Household data & $\begin{array}{l}\text { Lower JS leads to lower average tenure. Higher decline in formal sect } \\
\text { Hazard rates increase just at the end of probation period. }\end{array}$ \\
\hline $\begin{array}{l}\text { Hopenhayn (This } \\
\text { volume) }\end{array}$ & Argentina & Household data Rotating Panel & $\begin{array}{l}\text { Deregulation of temporary contracts leads to increase in hazard rates. } \\
\text { Hazard rates for short spells (1-3 months) increase by } 40 \% \text { and for } 3-6 \\
\text { months spells by } 10 \% \text {. }\end{array}$ \\
\hline
\end{tabular}

B. Studies that analyze average employment and unemployment

\begin{tabular}{|c|c|c|}
\hline $\begin{array}{l}\text { Kugler } \\
\text { (This volume) }\end{array}$ & Colombia Household data on employment. & $\begin{array}{l}\text { Decline in JS in } 1990 \text { brings a decline in unemployment rates. This is } \\
\text { based on computing the net effect of changes in hazard rates, in and out of } \\
\text { unemployment, induced by the reduction in JS. }\end{array}$ \\
\hline
\end{tabular}

Saavedra and Torero Peru

(This volume)

Mondino and

Montoya

(This volume)

P. de Barros and

Corseuil (2000)

Downes et al. (This volume)

Pagés and

Montenegro (1999)

Marquez (1998)
Argentina

(a)

Brazil

Trinidad

Jamaica

Chile

Cross-

Country
Firm and sector level data. 1986-1997 They include a direct measure of JS regulations in labor demand function. They estimate a negative and statistically significant coefficient, which is larger (in absolute value) in the more regulated period.

As Saavedra and Torero (this volume), they include a direct measure of JS in labor demand. They also find a negative effect of JS on LD. not account for firm creation.

Two step procedure. First, find parameters for labor demand (LD) function for every month. Then see whether those parameters change with labor reforms and other development. They find no effect of JS on LD parameters.

The effects of JS on employment are statistically insignificant and the signs are positive in some cases.

Not a significant effect of JS on aggregated employment but important effect on its composition. Annual 1960-1998

Rank indicator of Job Security. JS is not significantly associated with lower employment once GDP per capita is accounted for.

\begin{tabular}{|c|c|c|c|}
\hline \multicolumn{4}{|c|}{ C. Studies that analyze the composition of employment } \\
\hline Marquez (1998) & $\begin{array}{l}\text { Cross- } \\
\text { Country }\end{array}$ & $\begin{array}{l}\text { Cross-section data for Latin America, } \\
\text { Caribbean and OECD countries. }\end{array}$ & $\begin{array}{l}\text { Self-employment rates are positively associated with JS even after } \\
\text { accounting for differences in GDP per capita. }\end{array}$ \\
\hline $\begin{array}{l}\text { Montenegro and } \\
\text { Pagés (This volume) }\end{array}$ & Chile & Household Survey Data. 1960-1998 & $\begin{array}{l}\text { Job security is associated with lower employment rates for young workers, } \\
\text { female and unskilled workers and higher employment for older and skilled } \\
\text { workers }\end{array}$ \\
\hline
\end{tabular}


Table 7: Summary Statistics of Sample used in Baseline Regression

\begin{tabular}{|c|c|c|c|}
\hline Variable & Mean & Std. Dev. & $\operatorname{Max}$ \\
\hline \multicolumn{4}{|c|}{ A. Total Sample. $\mathrm{N}=417$} \\
\hline Employment/Population & 54.92 & 7.16 & 36.9076 .89 \\
\hline Unemployment Rate ${ }^{\dagger}$ & 7.82 & 4.33 & 0.5023 .80 \\
\hline Log GDP per capita PPP adj. & 9.43 & 0.63 & 7.3510 .37 \\
\hline GDP growth & 2.92 & 2.77 & -8.5912 .82 \\
\hline Share of working age pop. $25-54$ & 0.62 & 0.03 & 0.51 \\
\hline Share of working age pop. $55-64$ & 0.14 & 0.03 & 0.06 \\
\hline Social Security (\% wage) & 0.27 & 0.15 & 0.00 \\
\hline Advance notice $(*)$ & 0.82 & 0.48 & 0.00 \\
\hline Indemnities for Dismissal $(*)$ & 1.27 & 1.40 & 0.00 \\
\hline Seniority Pay $(*)$ & 0.65 & 2.35 & 0.00 \\
\hline Social Security $(*)$ & 35.65 & 19.13 & 0.0091 .53 \\
\hline Social Security $(* *)$ & 0.274 & 0.147 & $0.00 \quad 0.70$ \\
\hline \multicolumn{4}{|c|}{ B. Latin America. $\mathrm{N}=88$} \\
\hline Employment/Population & 59.09 & 5.35 & 47.1076 .89 \\
\hline Unemployment Rate & 6.52 & 3.23 & 0.6317 .10 \\
\hline Log GDP per capita PPP adj. & 8.49 & 0.45 & $7.35 \quad 9.44$ \\
\hline GDP growth & 3.31 & 3.60 & -8.5912 .82 \\
\hline Share of working age pop. $25-54$ & 0.58 & 0.03 & 0.51 \\
\hline Share of working age pop. $55-64$ & 0.09 & 0.02 & 0.06 \\
\hline Social Security (\% wage) & 0.23 & 0.08 & 0.10 \\
\hline Advance notice $(*)$ & 0.65 & 0.45 & 0.00 \\
\hline Indemnities for Dismissal (*) & 2.82 & 1.05 & 0.00 \\
\hline Seniority Pay $(*)$ & 3.09 & 4.33 & $0.00 \quad 9.82$ \\
\hline Social Security $(*)$ & 30.14 & 10.17 & 12.9853 .87 \\
\hline Social Security $(* *)$ & 0.23 & 0.07 & $\begin{array}{ll}0.1 \quad 0.41 \\
\end{array}$ \\
\hline \multicolumn{4}{|c|}{ C. Industrial Countries Sample. $\mathrm{N}=329$} \\
\hline Employment/Population & 53.81 & 7.17 & 36.9068 .60 \\
\hline Unemployment Rate & 8.17 & 4.52 & 0.5023 .80 \\
\hline Log GDP per capita PPP adj. & 9.68 & 0.38 & 8.5010 .37 \\
\hline GDP growth & 2.81 & 2.50 & -7.0010 .74 \\
\hline Share of working age pop. $25-54$ & 0.62 & 0.03 & 0.57 \\
\hline Share of working age pop. $55-64$ & 0.15 & 0.02 & 0.09 \\
\hline Social Security (\% wage) & 0.29 & 0.16 & 0.00 \\
\hline Advance notice $(*)$ & 0.87 & 0.48 & 0.00 \\
\hline Indemnities for Dismissal & 0.86 & 1.17 & 0.00 \\
\hline Seniority Pay & 0.00 & 0.00 & $0.00 \quad 0.00$ \\
\hline Social Security (*) & 37.12 & 20.65 & 0.0091 .53 \\
\hline Social Security $(* *)$ & 0.285 & 0.159 & $0.00 \quad 0.70$ \\
\hline
\end{tabular}

(*) Regulatory variables measured in multiples of monthly wages, $\left({ }^{* *}\right)$ measured as \% of wages ${ }^{\dagger} \mathrm{N}=416 ;{ }^{\dagger} \mathrm{N}=328$ 
Table 8A: Results for Employment to Population Rates

\begin{tabular}{|c|c|c|c|c|c|c|c|}
\hline & $\begin{array}{c}\text { Whole } \\
\text { Sample } \\
\text { (1) }\end{array}$ & $\begin{array}{c}\text { Whole } \\
\text { Sample } \\
\text { (2) }\end{array}$ & $\begin{array}{c}\text { Whole } \\
\text { Sample } \\
\text { (3) }\end{array}$ & $\begin{array}{c}\text { Whole } \\
\text { Sample } \\
\text { (4) }\end{array}$ & $\begin{array}{c}\text { Whole } \\
\text { Sample } \\
(5)\end{array}$ & $\begin{array}{c}\text { OECD } \\
\text { Sample } \\
(6)\end{array}$ & $\begin{array}{c}\text { LA } \\
\text { Sample } \\
(7)\end{array}$ \\
\hline $\begin{array}{l}\text { Advance } \\
\text { Notice (AN) }\end{array}$ & $\begin{array}{c}13.938 \\
(15.959)\end{array}$ & $\begin{array}{c}12.400 \\
(16.841)\end{array}$ & & & & $\begin{array}{c}13.755 \\
(14.564)\end{array}$ & $\begin{array}{c}16.637 \\
(15.420)\end{array}$ \\
\hline $\begin{array}{l}\text { Indemnities } \\
\text { Dismissal (ID) }\end{array}$ & $\begin{array}{l}1.161 \\
(0.897)\end{array}$ & & $\begin{array}{l}-0.469 \\
(0.730)\end{array}$ & & & $\begin{array}{l}-2.577 \\
(1.196)^{*}\end{array}$ & $\begin{array}{c}0.330 \\
(1.637)\end{array}$ \\
\hline $\begin{array}{l}\text { Seniority } \\
\text { Pay (SenP) }\end{array}$ & $\begin{array}{c}3.292 \\
(1.195)^{* *}\end{array}$ & & & $\begin{array}{c}1.837 \\
(0.213)^{* *}\end{array}$ & & N.A. & $\begin{array}{l}1.887 \\
(2.197)\end{array}$ \\
\hline $\begin{array}{l}\text { Social Sec } \\
\text { Cont. (SSC) }\end{array}$ & $\begin{array}{l}-0.230 \\
(0.081)^{* *}\end{array}$ & & & & $\begin{array}{l}-0.191 \\
(0.079)^{*}\end{array}$ & $\begin{array}{c}-0.301 \\
(0.102)^{* *}\end{array}$ & $\begin{array}{l}-0.187 \\
(0.084)^{*}\end{array}$ \\
\hline GDP growth & $\begin{array}{c}0.094 \\
(0.046)^{*}\end{array}$ & $\begin{array}{c}0.125 \\
(0.050)^{*}\end{array}$ & $\begin{array}{c}0.123 \\
(0.049)^{*}\end{array}$ & $\begin{array}{c}0.110 \\
(0.042)^{* *}\end{array}$ & $\begin{array}{c}0.108 \\
(0.046)^{*}\end{array}$ & $\begin{array}{c}0.034 \\
(0.050)\end{array}$ & $\begin{array}{c}0.106 \\
(0.072)\end{array}$ \\
\hline $\begin{array}{l}\text { Log GDP per } \\
\text { Capita }\end{array}$ & $\begin{array}{l}2.318 \\
(1.277)\end{array}$ & $\begin{array}{l}-0.320 \\
(1.044)\end{array}$ & $\begin{array}{c}-0.451 \\
(1.079)\end{array}$ & $\begin{array}{c}0.834 \\
(2.253)\end{array}$ & $\begin{array}{l}3.122 \\
(2.260)\end{array}$ & $\begin{array}{l}1.828 \\
(1.334)\end{array}$ & $\begin{array}{l}11.639 \\
(8.152)\end{array}$ \\
\hline $\begin{array}{l}\text { Share WAP } \\
25-54\end{array}$ & $\begin{array}{c}17.584 \\
(16.750)\end{array}$ & $\begin{array}{c}29.171 \\
(16.608)\end{array}$ & $\begin{array}{c}33.259 \\
(18.135)\end{array}$ & $\begin{array}{c}22.143 \\
(21.704)\end{array}$ & $\begin{array}{c}16.534 \\
(23.535)\end{array}$ & $\begin{array}{c}12.112 \\
(19.197)\end{array}$ & $\begin{array}{c}9.126 \\
(70.273)\end{array}$ \\
\hline $\begin{array}{l}\text { Share WAP } \\
55-64\end{array}$ & $\begin{array}{c}48.456 \\
(35.685)\end{array}$ & $\begin{array}{c}20.450 \\
(27.018)\end{array}$ & $\begin{array}{c}27.060 \\
(27.465)\end{array}$ & $\begin{array}{c}20.614 \\
(26.721)\end{array}$ & $\begin{array}{c}59.725 \\
(33.501)\end{array}$ & $\begin{array}{c}50.009 \\
(35.553)\end{array}$ & $\begin{array}{c}-197.99 \\
(317.709)\end{array}$ \\
\hline Constant & $\begin{array}{c}13.588 \\
(17.743)\end{array}$ & $\begin{array}{c}28.759 \\
(18.736)\end{array}$ & $\begin{array}{l}37.614 \\
(13.754)^{* *}\end{array}$ & $\begin{array}{c}32.086 \\
(13.318)^{*}\end{array}$ & $\begin{array}{c}17.013 \\
(13.165)\end{array}$ & $\begin{array}{c}8.519 \\
(31.305)\end{array}$ & $\begin{array}{l}-40.525 \\
(55.759)\end{array}$ \\
\hline $\begin{array}{l}\text { Number of } \\
\text { Observations }\end{array}$ & 417 & 476 & 480 & 564 & 484 & 329 & 88 \\
\hline $\begin{array}{l}\mathrm{R}^{2} \\
\mathrm{P}-\text { Value } \mathrm{F} \text { test }\end{array}$ & $\begin{array}{l}0.91 \\
0.00\end{array}$ & 0.90 & 0.89 & 0.88 & 0.90 & $\begin{array}{l}0.93 \\
0.04\end{array}$ & $\begin{array}{l}0.82 \\
0.00\end{array}$ \\
\hline
\end{tabular}

Robust standard errors in parentheses. All specification include country fixed effects. * indicates significant at 5\% level; ** significant at $1 \%$ level; *** P Value of test that all regulation are jointly equal to zero. N.A. = not applicable. WAP denotes Working Age Population 
Table 8B: Results for Unemployment

\begin{tabular}{|c|c|c|c|c|c|c|c|}
\hline & $\begin{array}{c}\text { Whole } \\
\text { Sample } \\
(1)\end{array}$ & $\begin{array}{l}\text { Whole } \\
\text { Sample } \\
(2)\end{array}$ & $\begin{array}{c}\text { Whole } \\
\text { Sample } \\
(3)\end{array}$ & $\begin{array}{l}\text { Whole } \\
\text { Sample } \\
(4)\end{array}$ & $\begin{array}{l}\text { Whole } \\
\text { Sample } \\
(5)\end{array}$ & $\begin{array}{l}\text { OECD } \\
\text { Sample } \\
(6)\end{array}$ & $\begin{array}{c}\text { LA } \\
\text { Sample } \\
(7)\end{array}$ \\
\hline $\begin{array}{l}\text { Advance } \\
\text { Notice (AN) }\end{array}$ & $\begin{array}{c}-9.13 \\
(11.08)\end{array}$ & $\begin{array}{c}-7.29 \\
(11.03)\end{array}$ & & & & $\begin{array}{c}-9.19 \\
(10.62)\end{array}$ & $\begin{array}{c}4.06 \\
(9.96)\end{array}$ \\
\hline $\begin{array}{l}\text { Indemnities } \\
\text { Dismissal (ID) }\end{array}$ & $\begin{array}{c}0.50 \\
(1.00)\end{array}$ & & $\begin{array}{l}-0.01 \\
(0.40)\end{array}$ & & & $\begin{array}{c}3.00 \\
(1.01)^{* *}\end{array}$ & $\begin{array}{c}0.43 \\
(1.12)\end{array}$ \\
\hline $\begin{array}{l}\text { Seniority } \\
\text { Pay (SenP) }\end{array}$ & $\begin{array}{c}0.79 \\
(1.33)\end{array}$ & & & $\begin{array}{c}0.21 \\
(0.13)\end{array}$ & & N.A. & $\begin{array}{c}0.84 \\
(1.43)\end{array}$ \\
\hline $\begin{array}{l}\text { Soc. Sec. } \\
\text { Cont. (SSC) }\end{array}$ & $\begin{array}{c}0.18 \\
(0.07)^{*}\end{array}$ & & & & $\begin{array}{c}0.13 \\
(0.05)^{*}\end{array}$ & $\begin{array}{c}0.22 \\
(0.09)^{*}\end{array}$ & $\begin{array}{c}0.15 \\
(0.09)\end{array}$ \\
\hline GDP growth & $\begin{array}{l}-0.16 \\
(0.04)^{* *}\end{array}$ & $\begin{array}{c}-0.19 \\
(0.05)^{* *}\end{array}$ & $\begin{array}{l}-0.18 \\
(0.04)^{* *}\end{array}$ & $\begin{array}{c}-0.18 \\
(0.05)^{* *}\end{array}$ & $\begin{array}{c}-0.14 \\
(0.04)^{* *}\end{array}$ & $\begin{array}{c}-0.13 \\
(0.05)^{*}\end{array}$ & $\begin{array}{c}-0.23 \\
(0.09)^{*}\end{array}$ \\
\hline $\begin{array}{l}\text { GDP per } \\
\text { Capita }\end{array}$ & $\begin{array}{l}-2.28 \\
(1.26)\end{array}$ & $\begin{array}{l}1.78 \\
(1.27)\end{array}$ & $\begin{array}{l}1.55 \\
(1.05)\end{array}$ & $\begin{array}{c}1.87 \\
(1.28)\end{array}$ & $\begin{array}{l}-1.47 \\
(1.30)\end{array}$ & $\begin{array}{l}-2.70 \\
(1.36)\end{array}$ & $\begin{array}{c}4.37 \\
(3.13)\end{array}$ \\
\hline $\begin{array}{l}\text { Share WAP } \\
25-54\end{array}$ & $\begin{array}{c}18.85 \\
(14.26)\end{array}$ & $\begin{array}{c}-2.72 \\
(16.00)\end{array}$ & $\begin{array}{c}-5.72 \\
(16.72)\end{array}$ & $\begin{array}{c}-4.27 \\
(14.98)\end{array}$ & $\begin{array}{c}17.19 \\
(16.96)\end{array}$ & $\begin{array}{c}25.20 \\
(16.44)\end{array}$ & $\begin{array}{c}-66.30 \\
(29.54)^{*}\end{array}$ \\
\hline $\begin{array}{l}\text { Share WAP } \\
55-64\end{array}$ & $\begin{array}{c}-7.35 \\
(28.58)\end{array}$ & $\begin{array}{c}6.69 \\
(24.90)\end{array}$ & $\begin{array}{c}2.17 \\
(25.19)\end{array}$ & $\begin{array}{l}-15.41 \\
(22.29)\end{array}$ & $\begin{array}{l}-14.69 \\
(25.26)\end{array}$ & $\begin{array}{c}-7.97 \\
(31.36)\end{array}$ & $\begin{array}{c}134.98 \\
(214.64)\end{array}$ \\
\hline Constant & $\begin{array}{c}23.01 \\
(13.02)\end{array}$ & $\begin{array}{c}1.13 \\
(12.88)\end{array}$ & $\begin{array}{l}-3.20 \\
(9.99)\end{array}$ & $\begin{array}{c}1.05 \\
(7.40)\end{array}$ & $\begin{array}{l}13.19 \\
(7.63)\end{array}$ & $\begin{array}{c}28.44 \\
(23.31)\end{array}$ & $\begin{array}{c}-16.54 \\
(34.32)\end{array}$ \\
\hline $\begin{array}{l}\text { Number of } \\
\text { observations. } \\
\mathrm{R}^{2} \\
\text { P-Value } \mathrm{F}^{* * *}\end{array}$ & $\begin{array}{l}0.84 \\
0.02\end{array}$ & 0.79 & 0.78 & 0.79 & 0.84 & $\begin{array}{l}0.86 \\
0.03\end{array}$ & $\begin{array}{l}0.72 \\
0.00\end{array}$ \\
\hline
\end{tabular}


Table 9: Do all regulations have an equal effect? : Whole Sample

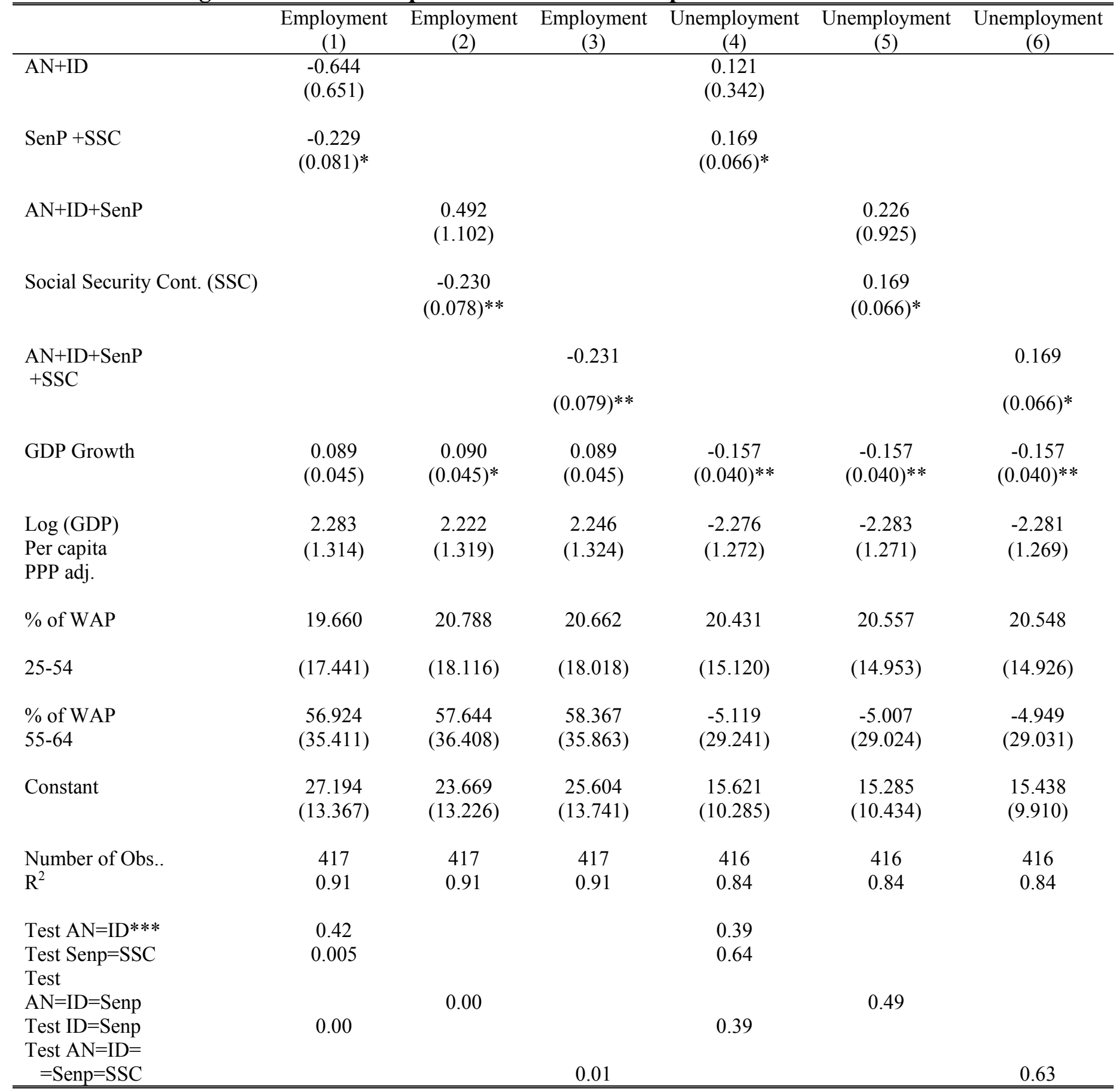

Robust standard errors in parentheses. All specifications contain individual countries, fixed-effects* significant at $5 \%$ level; ** significant at $1 \%$ level; *** P-Values of the Tests in this row and below. WAP denotes Working Age Population 
Table 10: Estimates of Wage Pass-Through for Different Labor Demand Elasticities.

\begin{tabular}{ccccc}
\hline \hline & $\begin{array}{c}\text { Labor } \\
\text { Demand } \\
\text { Elasticity }\end{array}$ & $\begin{array}{c}\text { Whole } \\
\text { Sample }\end{array}$ & $\begin{array}{c}\text { OECD } \\
\text { Sample }\end{array}$ & $\begin{array}{c}\text { Latin American } \\
\text { Sample }\end{array}$ \\
\hline$\frac{\partial \ln E m p^{*}}{\partial \ln S S}$ & N/A & -.702 & -1.048 & -.447 \\
$\frac{\partial \ln W}{\partial \ln S S}$ & -0.15 & 0 & $(0.381)^{* *}$ & $(0.270)$ \\
$\frac{\partial \ln W}{\partial \ln S S}$ & -0.7 & 0 & 0 & 0 \\
$\frac{\partial \ln W}{\partial \ln S S}$ & -1.2 & -.415 & 0 & -.36 \\
\hline $\ln E *)^{* *}$ & & & -.12 & -.62 \\
\hline
\end{tabular}

*: $\frac{\partial \ln E m p}{\partial \ln S S}$ is obtained from a regression in which the dependent variable is computed in logarithms and all regulatory variables are also computed in logs. The other control variables used in Table 8A are used here. Social security contributions are defined as logarithms of the fraction of the contribution rate, that is we use $\ln (1+S S)$. Standard errors are in parentheses. The other three rows are obtained from the formula in the text, using alternative values of $\alpha$, as shown in the first column of the table. When estimated effects on wages are positive, they are constrained to be zero. ${ }^{* *}$ Statistically significant at the $5 \%$ level. 
Table 11: The effect of pension reforms on employment and unemployment

\begin{tabular}{|c|c|c|c|c|c|c|}
\hline & $\begin{array}{c}\text { Emp. } \\
\text { Whole } \\
\text { Sample } \\
(1)\end{array}$ & $\begin{array}{c}\text { Emp. } \\
\text { OECD } \\
\text { Sample } \\
(2)\end{array}$ & $\begin{array}{c}\text { Emp. } \\
\text { Latin A. } \\
\text { Sample } \\
(3)\end{array}$ & $\begin{array}{l}\text { Unemp. } \\
\text { Whole } \\
\text { Sample } \\
\text { (4) }\end{array}$ & $\begin{array}{c}\text { Unemp. } \\
\text { OECD } \\
\text { Sample } \\
(5)\end{array}$ & $\begin{array}{c}\text { Unemp. } \\
\text { Latin A. } \\
\text { Sample } \\
\text { (6) }\end{array}$ \\
\hline $\begin{array}{l}\text { Adv. Notice } \\
\text { (AN) }\end{array}$ & $\begin{array}{c}14.08 \\
(15.629)\end{array}$ & (14.564) & (14.721) & (11.011) & (10.617) & (11.379) \\
\hline $\begin{array}{l}\text { Indem Dismissal } \\
\text { (ID) }\end{array}$ & $\begin{array}{c}1.286 \\
(0.979)\end{array}$ & $\begin{array}{c}-2.577 \\
(1.196)^{*}\end{array}$ & $\begin{array}{c}0.087 \\
(1.702)\end{array}$ & $\begin{array}{c}0.470 \\
(1.001)\end{array}$ & $\begin{array}{c}3.005 \\
(1.008)^{* *}\end{array}$ & $\begin{array}{c}0.742 \\
(1.089)\end{array}$ \\
\hline $\begin{array}{l}\text { Seniority Pay } \\
\text { (SenP) }\end{array}$ & $\begin{array}{c}3.480 \\
(1.305)^{*}\end{array}$ & $\begin{array}{c}0.000 \\
(0.000)\end{array}$ & $\begin{array}{l}1.624 \\
(2.299)\end{array}$ & $\begin{array}{c}0.739 \\
(1.332)\end{array}$ & N.A. & $\begin{array}{c}1.247 \\
(1.406)\end{array}$ \\
\hline $\begin{array}{l}\text { Soc. Sec. Cont. } \\
\text { (SSC) }\end{array}$ & $\begin{array}{c}-0.253 \\
(0.088)^{* *}\end{array}$ & $\begin{array}{c}-0.301 \\
(0.102)^{*}\end{array}$ & $\begin{array}{l}-0.168 \\
(0.086)\end{array}$ & $\begin{array}{c}0.173 \\
(0.071)^{*}\end{array}$ & $\begin{array}{c}0.215 \\
(0.098)^{*}\end{array}$ & $\begin{array}{c}0.118 \\
(0.087)\end{array}$ \\
\hline SSC Reform & $\begin{array}{c}-0.138 \\
(0.072)\end{array}$ & $\begin{array}{c}0.000 \\
(0.000)\end{array}$ & $\begin{array}{c}-0.327 \\
(0.134)^{*}\end{array}$ & $\begin{array}{c}0.124 \\
(0.044)^{* *}\end{array}$ & $\begin{array}{c}0.000 \\
(0.000)\end{array}$ & $\begin{array}{c}0.248 \\
(0.109)^{*}\end{array}$ \\
\hline Reform & $\begin{array}{c}7.290 \\
(3.174)^{*}\end{array}$ & $\begin{array}{c}0.000 \\
(0.000)\end{array}$ & $\begin{array}{c}10.665 \\
(4.765)^{*}\end{array}$ & $\begin{array}{c}-4.349 \\
(1.926)^{*}\end{array}$ & $\begin{array}{c}0.000 \\
(0.000)\end{array}$ & $\begin{array}{l}-7.234 \\
(3.758)\end{array}$ \\
\hline GDP growth & $\begin{array}{c}0.096 \\
(0.048)\end{array}$ & $\begin{array}{c}0.034 \\
(0.050)\end{array}$ & $\begin{array}{c}0.123 \\
(0.084)\end{array}$ & $\begin{array}{c}-0.164 \\
(0.041)^{* *}\end{array}$ & $\begin{array}{c}-0.130 \\
(0.053)^{*}\end{array}$ & $\begin{array}{c}-0.239 \\
(0.086)^{*}\end{array}$ \\
\hline Log GDP pc & $\begin{array}{c}2.348 \\
(1.227)\end{array}$ & $\begin{array}{c}1.828 \\
(1.334)\end{array}$ & $\begin{array}{l}10.742 \\
(7.643)\end{array}$ & $\begin{array}{l}-2.336 \\
(1.236)\end{array}$ & $\begin{array}{l}-2.700 \\
(1.355)\end{array}$ & $\begin{array}{c}4.983 \\
(3.292)\end{array}$ \\
\hline$\%$ WAP $25-54$ & $\begin{array}{c}15.011 \\
(16.884)\end{array}$ & $\begin{array}{c}12.112 \\
(19.197)\end{array}$ & $\begin{array}{c}34.692 \\
(69.954)\end{array}$ & $\begin{array}{c}20.505 \\
(14.199)\end{array}$ & $\begin{array}{c}25.196 \\
(16.442)\end{array}$ & $\begin{array}{l}-93.257 \\
(34.205)^{*}\end{array}$ \\
\hline$\%$ WAP 55-64 & $\begin{array}{c}45.690 \\
(35.828)\end{array}$ & $\begin{array}{c}50.009 \\
(35.553)\end{array}$ & $\begin{array}{l}-449.346 \\
(298.027)\end{array}$ & $\begin{array}{c}-2.593 \\
(28.761)\end{array}$ & $\begin{array}{c}-7.975 \\
(31.360)\end{array}$ & $\begin{array}{c}365.975 \\
(223.294)\end{array}$ \\
\hline Constant & $\begin{array}{c}15.044 \\
(17.348)\end{array}$ & $\begin{array}{c}8.519 \\
(31.305)\end{array}$ & $\begin{array}{c}1.087 \\
(52.262)\end{array}$ & $\begin{array}{c}20.739 \\
(12.965)\end{array}$ & $\begin{array}{c}28.443 \\
(23.305)\end{array}$ & $\begin{array}{l}-49.617 \\
(36.657)\end{array}$ \\
\hline $\begin{array}{l}\mathrm{N} \\
\mathrm{R}^{2}\end{array}$ & $\begin{array}{l}417 \\
0.92\end{array}$ & $\begin{array}{c}329 \\
0.93\end{array}$ & $\begin{array}{c}88 \\
0.84\end{array}$ & $\begin{array}{l}416 \\
0.84\end{array}$ & $\begin{array}{l}328 \\
0.86\end{array}$ & $\begin{array}{c}88 \\
0.76\end{array}$ \\
\hline
\end{tabular}

Robust standard errors in parentheses. See Appendix A.1 for a definition of Reform variable. ${ }^{*}$ significant at $5 \%$ level; ${ }^{* *}$ significant at $1 \%$ level. N.A. $=$ not applicable. WAP denotes Working Age Population 


\begin{tabular}{|c|c|c|c|c|c|c|}
\hline & $\begin{array}{l}\text { Emp. } \\
\text { Total } \\
\text { Sample } \\
\text { (1) }\end{array}$ & $\begin{array}{l}\text { Emp. } \\
\text { OECD } \\
\text { (2) }\end{array}$ & $\begin{array}{l}\text { Emp. } \\
\text { LAC } \\
\text { (3) }\end{array}$ & $\begin{array}{l}\text { Unemp. } \\
\text { Total } \\
\text { Sample } \\
\text { (4) }\end{array}$ & $\begin{array}{l}\text { Unemp. } \\
\text { OECD } \\
\text { (5) }\end{array}$ & $\begin{array}{l}\text { Unemp. } \\
\text { LAC } \\
\text { (6) }\end{array}$ \\
\hline $\begin{array}{l}\text { Advance } \\
\text { Notice (AN) }\end{array}$ & $\begin{array}{l}4.142 \\
(1.871)^{*}\end{array}$ & $\begin{array}{l}5.292 \\
(1.986)^{* *}\end{array}$ & $\begin{array}{l}1.417 \\
(4.461)\end{array}$ & $\begin{array}{l}-2.762 \\
(1.278)^{*}\end{array}$ & $\begin{array}{l}-3.560 \\
(1.733)^{*}\end{array}$ & $\begin{array}{l}-0.200 \\
(1.997)\end{array}$ \\
\hline $\begin{array}{l}\text { Indemnities } \\
\text { Diss. (ID) }\end{array}$ & $\begin{array}{l}-0.250 \\
(0.347)\end{array}$ & $\begin{array}{l}-1.010 \\
(0.809)\end{array}$ & $\begin{array}{l}-0.358 \\
(0.464)\end{array}$ & $\begin{array}{l}0.027 \\
(0.266)\end{array}$ & $\begin{array}{l}0.326 \\
(0.706)\end{array}$ & $\begin{array}{l}-0.048 \\
(0.298)\end{array}$ \\
\hline $\begin{array}{l}\text { Seniority Pay } \\
\text { (SenP) }\end{array}$ & $\begin{array}{l}0.899 \\
(0.331)^{* *}\end{array}$ & $\begin{array}{l}0.000 \\
(0.000)\end{array}$ & $\begin{array}{l}0.562 \\
(0.438)\end{array}$ & $\begin{array}{l}-0.074 \\
(0.225)\end{array}$ & $\begin{array}{l}0.000 \\
(0.000)\end{array}$ & $\begin{array}{l}0.009 \\
(0.202)\end{array}$ \\
\hline $\begin{array}{l}\text { Soc. Sec. } \\
\text { Contrib.(SSC) }\end{array}$ & $\begin{array}{l}-0.221 \\
(0.031)^{* *}\end{array}$ & $\begin{array}{l}-0.259 \\
(0.032)^{* *}\end{array}$ & $\begin{array}{l}-0.164 \\
(0.073)^{*}\end{array}$ & $\begin{array}{l}0.135 \\
(0.023)^{* *}\end{array}$ & $\begin{array}{l}0.153 \\
(0.029)^{* *}\end{array}$ & $\begin{array}{l}0.090 \\
(0.050)\end{array}$ \\
\hline $\begin{array}{l}\text { Growth of } \\
\text { GPD }\end{array}$ & $\begin{array}{l}0.089 \\
(0.046)\end{array}$ & $\begin{array}{l}0.030 \\
(0.051)\end{array}$ & $\begin{array}{l}0.123 \\
(0.097)\end{array}$ & $\begin{array}{l}-0.157 \\
(0.038)^{* *}\end{array}$ & $\begin{array}{l}-0.133 \\
(0.047)^{* *}\end{array}$ & $\begin{array}{l}-0.205 \\
(0.068)^{* *}\end{array}$ \\
\hline $\begin{array}{l}\text { Log GDP per } \\
\text { Capita (PPP) }\end{array}$ & $\begin{array}{l}2.292 \\
(0.826)^{* *}\end{array}$ & $\begin{array}{l}1.837 \\
(0.784)^{*}\end{array}$ & $\begin{array}{l}8.931 \\
(3.251)^{* *}\end{array}$ & $\begin{array}{l}-2.117 \\
(0.668)^{* *}\end{array}$ & $\begin{array}{l}-2.606 \\
(0.705)^{* *}\end{array}$ & $\begin{array}{l}1.607 \\
(1.869)\end{array}$ \\
\hline $\begin{array}{l}\text { Share of } \\
\text { WAP } \\
25-54\end{array}$ & $\begin{array}{l}17.462 \\
(10.657)\end{array}$ & $\begin{array}{l}8.760 \\
(10.682)\end{array}$ & $\begin{array}{l}21.529 \\
(37.575)\end{array}$ & $\begin{array}{l}21.471 \\
(8.598)^{*}\end{array}$ & $\begin{array}{l}26.494 \\
(9.616)^{* *}\end{array}$ & $\begin{array}{l}-11.405 \\
(22.081)\end{array}$ \\
\hline $\begin{array}{l}\text { Share of } \\
\text { WAP } \\
55-64\end{array}$ & $\begin{array}{l}48.130 \\
(20.842)^{*}\end{array}$ & $\begin{array}{l}34.748 \\
(21.002)\end{array}$ & $\begin{array}{l}-76.504 \\
(75.751)\end{array}$ & $\begin{array}{l}1.544 \\
(16.411)\end{array}$ & $\begin{array}{l}2.022 \\
(18.910)\end{array}$ & $\begin{array}{l}21.309 \\
(40.005)\end{array}$ \\
\hline Constant & $\begin{array}{l}18.202 \\
(6.616)^{* *}\end{array}$ & $\begin{array}{l}31.222 \\
(6.896)^{* *}\end{array}$ & $\begin{array}{l}-19.363 \\
(15.833)\end{array}$ & $\begin{array}{l}12.749 \\
(5.169)^{*}\end{array}$ & $\begin{array}{l}13.938 \\
(6.160)^{*}\end{array}$ & $\begin{array}{l}-3.868 \\
(9.823)\end{array}$ \\
\hline $\begin{array}{l}\text { Observations } \\
\text { Hausman Test } \\
\text { (Pvalue) } \\
\mathrm{R}^{2}\end{array}$ & $\begin{array}{l}0.09 \\
0.46\end{array}$ & $\begin{array}{l}0.03 \\
0.48\end{array}$ & $\begin{array}{l}0.00 \\
0.004\end{array}$ & $\begin{array}{l}0.25 \\
0.15\end{array}$ & $\begin{array}{l}0.01 \\
0.14\end{array}$ & $\begin{array}{l}0.51 \\
0.26\end{array}$ \\
\hline
\end{tabular}

Standard errors in parentheses. WAP denotes Working Age Population. Columns (1) and (4) include a dummy variable that identifies the region, and which takes the value equal to 1 if the country is in Latin America and zero otherwise. $*$ significant at $5 \%$ level; ** significant at $1 \%$ level. 
Table 13: Correlation between Dependency Ratio and social security contributions

\begin{tabular}{lccc}
\hline \hline & SSP & SSP & SSP \\
& Total & OECD & LA \\
\hline Dependency & 112.10 & 102.38 & 283.6 \\
Ratio & $(14.65)^{* *}$ & $(14.97)^{* *}$ & $(133.30)^{* *}$ \\
& & & \\
Country FE? & YES & YES & YES \\
Observations & 514 & 411 & 86 \\
R-squared & 0.09 & 0.09 & 0.46 \\
\hline \hline
\end{tabular}

Dependency ratio computed as the ratio of the population 65 and older to the working age population (15-64). Robust standard errors in parentheses; *significant at $5 \%$ level; ** significant at $1 \%$ level.

Table 14: Instrumental Variable Estimates

\begin{tabular}{lllllll}
\hline \hline & $\begin{array}{l}\text { Employment } \\
\text { Total }\end{array}$ & $\begin{array}{l}\text { Employment } \\
\text { OECD }\end{array}$ & $\begin{array}{l}\text { Employment } \\
\text { LA }\end{array}$ & $\begin{array}{l}\text { Unemployment } \\
\text { Total }\end{array}$ & $\begin{array}{l}\text { Unemployment } \\
\text { OECD }\end{array}$ & $\begin{array}{l}\text { Unemployment } \\
\text { LA }\end{array}$ \\
\hline Advance Notice & 26.66 & 23.77 & 30.77 & -15.72 & -15.10 & -12.73 \\
& $(16.26)$ & $(13.51)$ & $(24.61)$ & $(11.29)$ & $(10.01)$ & $(19.86)$ \\
Indemnities & -1.08 & -7.15 & 2.33 & 1.73 & 5.80 & -1.64 \\
Dismissal & $(2.31)$ & $(2.38)^{* *}$ & $(3.71)$ & $(1.68)$ & $(1.94)^{* *}$ & $(2.29)$ \\
Seniority Pay & -0.41 & 0.00 & 5.10 & 2.81 & 0.00 & -2.55 \\
& $(3.56)$ & $(0.00)$ & $(5.42)$ & $(2.50)$ & $(0.00)$ & $(3.22)$ \\
Soc. Sec. Cont. & -1.37 & -1.28 & 0.36 & 0.77 & 0.80 & -0.47 \\
& $(0.78)^{\dagger}$ & $(0.66)^{\dagger}$ & $(0.58)^{\dagger}$ & $(0.48)^{\dagger}$ & $(0.45)^{\dagger}$ & $(0.38)$ \\
Observations & 404 & 321 & 83 & 404 & 321 & 83 \\
R-squared & 0.70 & 0.79 & 0.70 & 0.67 & 0.74 & 0.33 \\
\hline \hline
\end{tabular}

All regressions include country fixed effects as well as GDP pc (PPP adjusted), GDP growth, and the share of workers in WAP between 25 and 54 and 55 and 64. We instrument Social Security Contributions (measures in EPV) with the dependency ratio, computed as the ratio of the population 65 and older to the working age population (15-64). Robust standard errors in parentheses. significant at 10\%; * significant at 5\% level; ** significant at $1 \%$ level. 


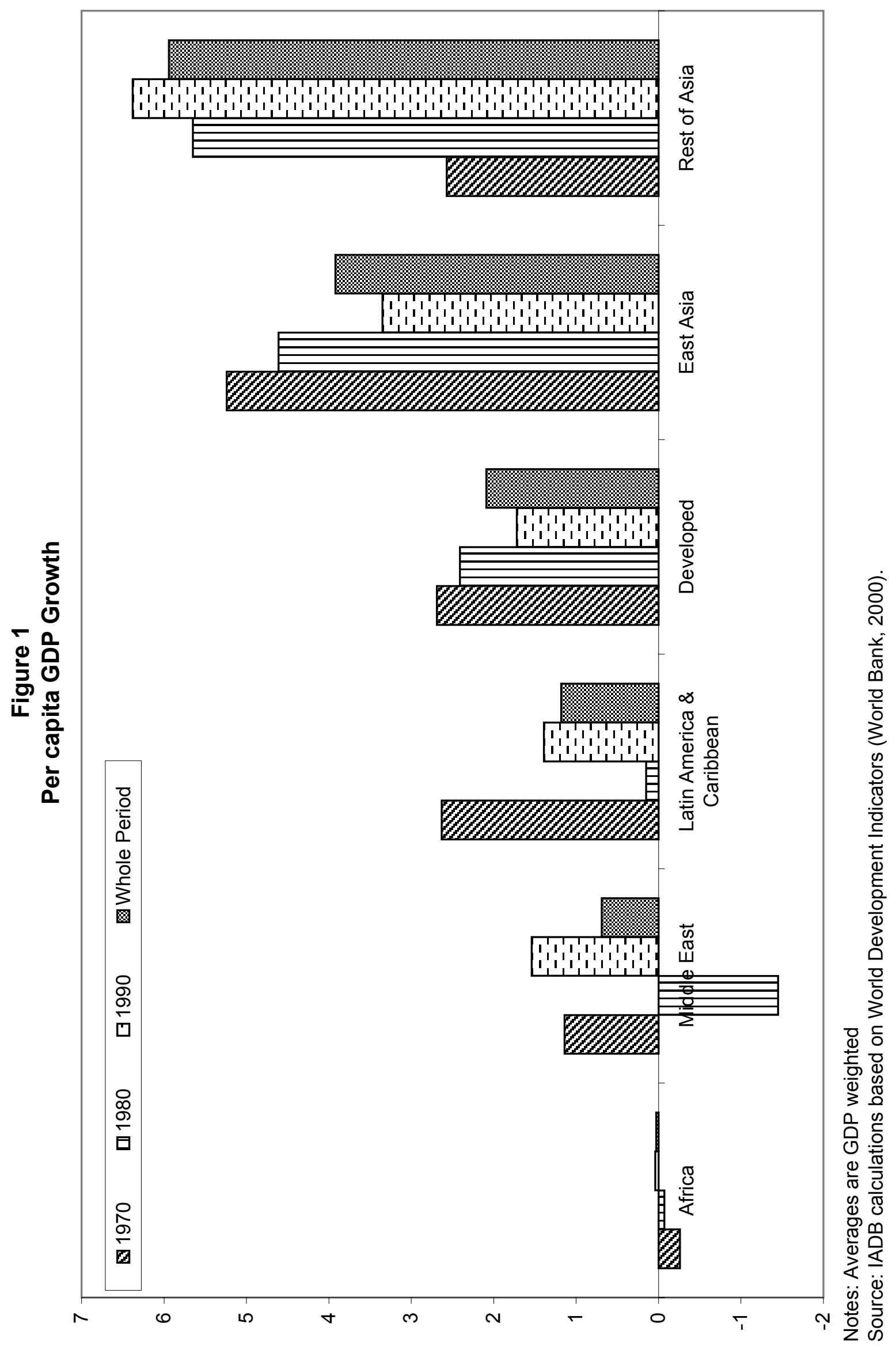


Figure 2: Minimum Wage/Mean Wage in OECD Countries* and in Latin America**

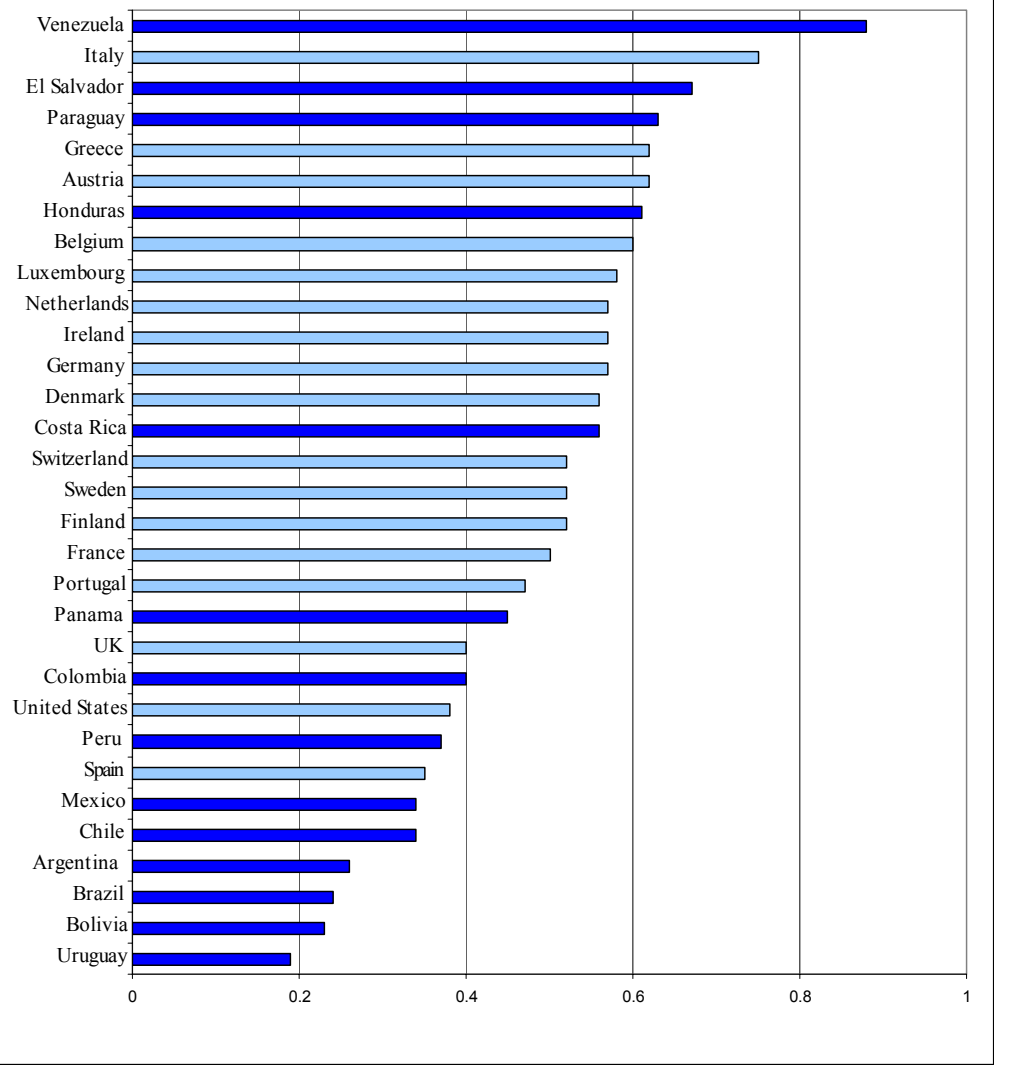

*Minimum wages from Dolado, et al. (1996), for one year within the range 1991 and 1995. **Minimum wages from 1995 or 1996 except: Argentina (1998), Bolivia (1997), Brazil (1998), Colombia (1998), Honduras (1999), Mexico (1999), and Uruguay (1998).

Source: Maloney and Nunez-Mendez (This volume). 


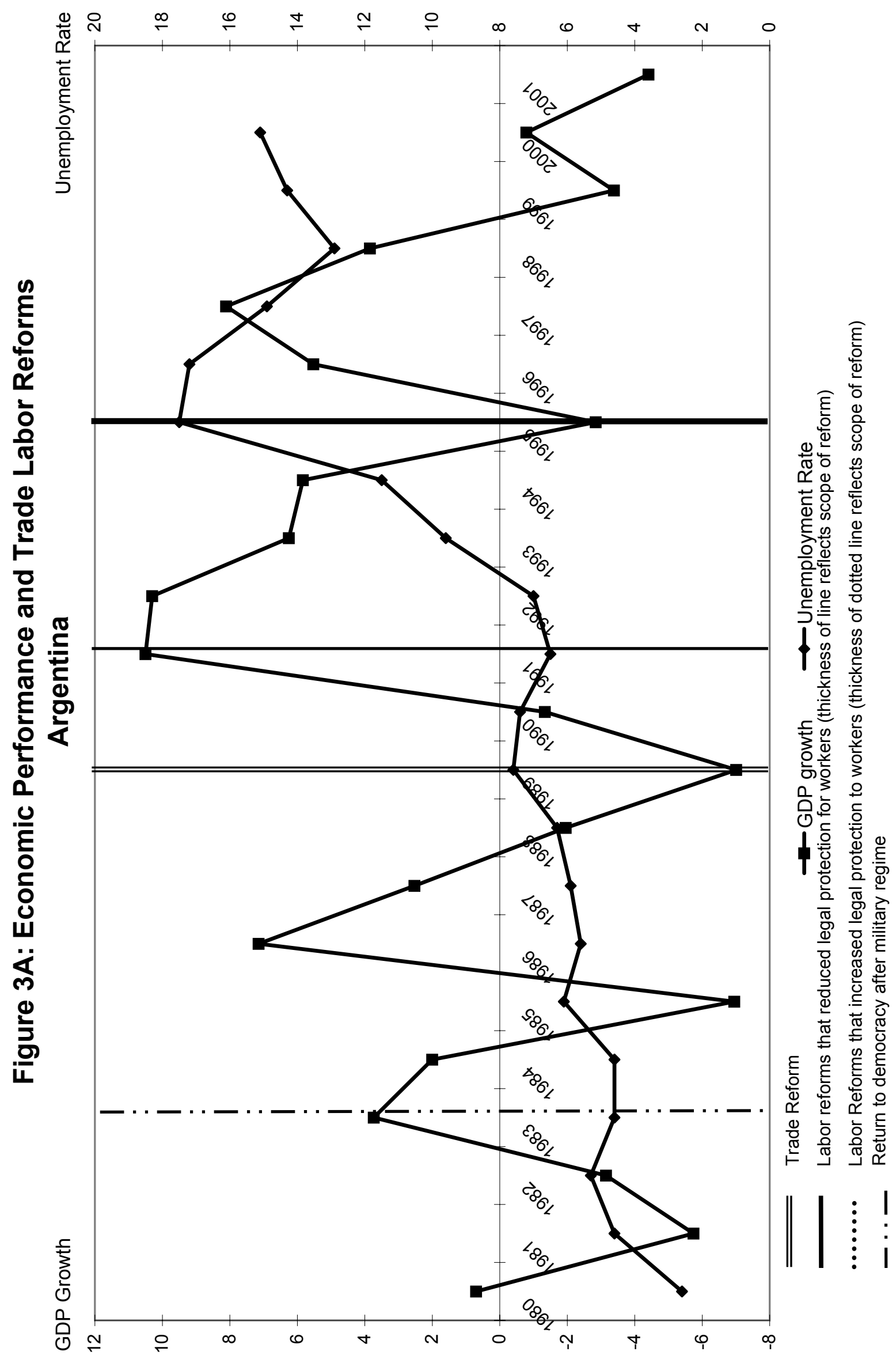




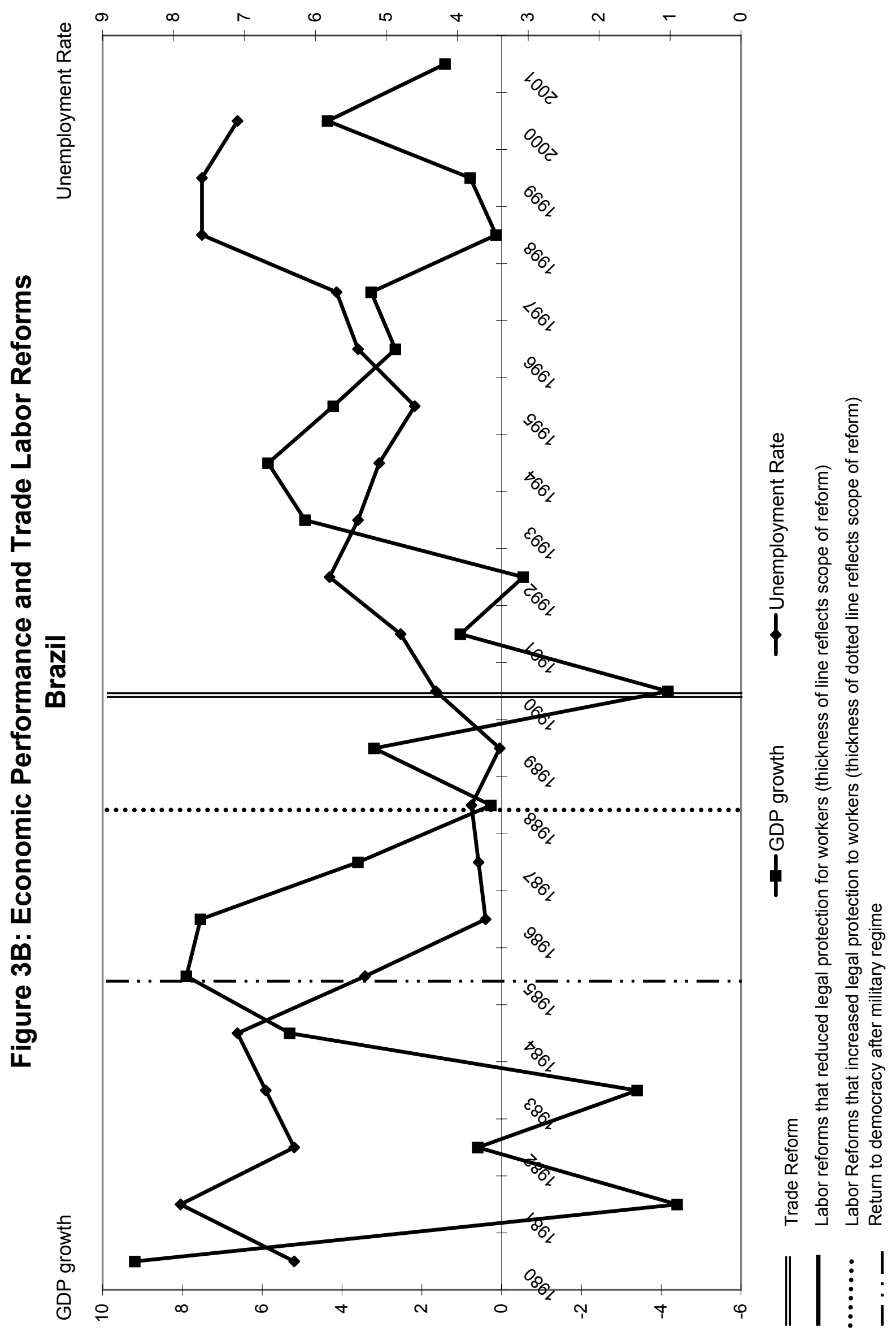




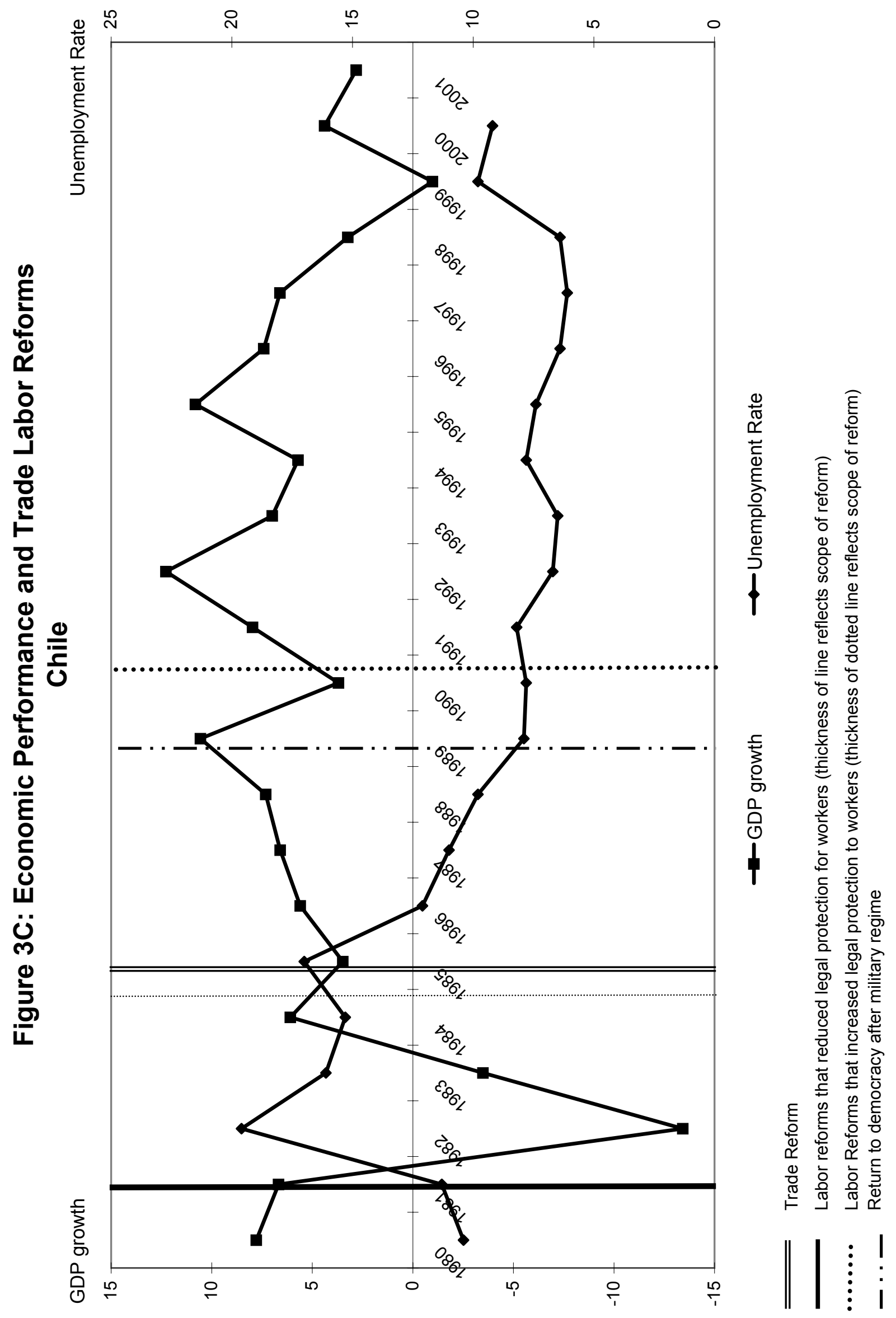




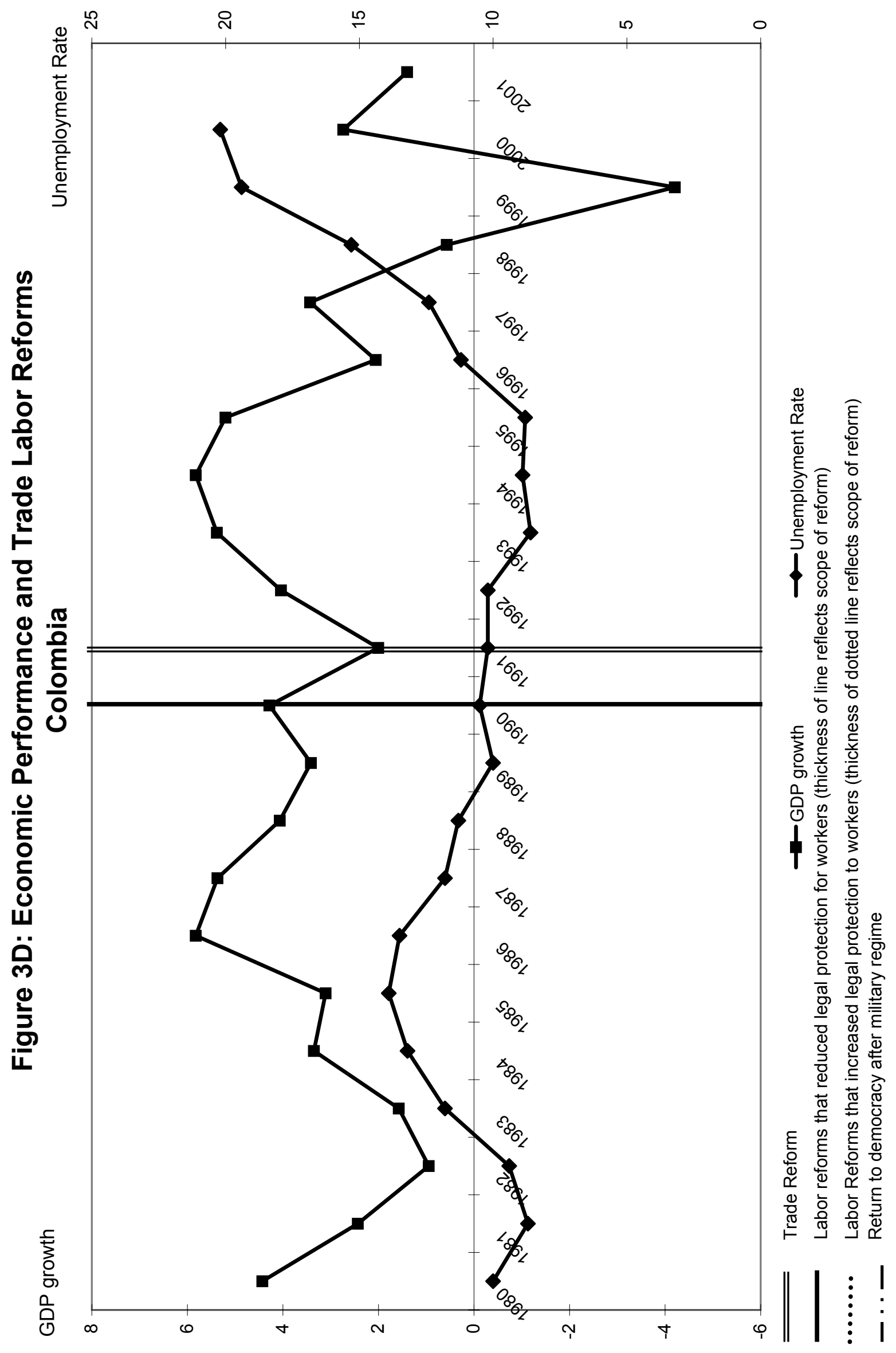




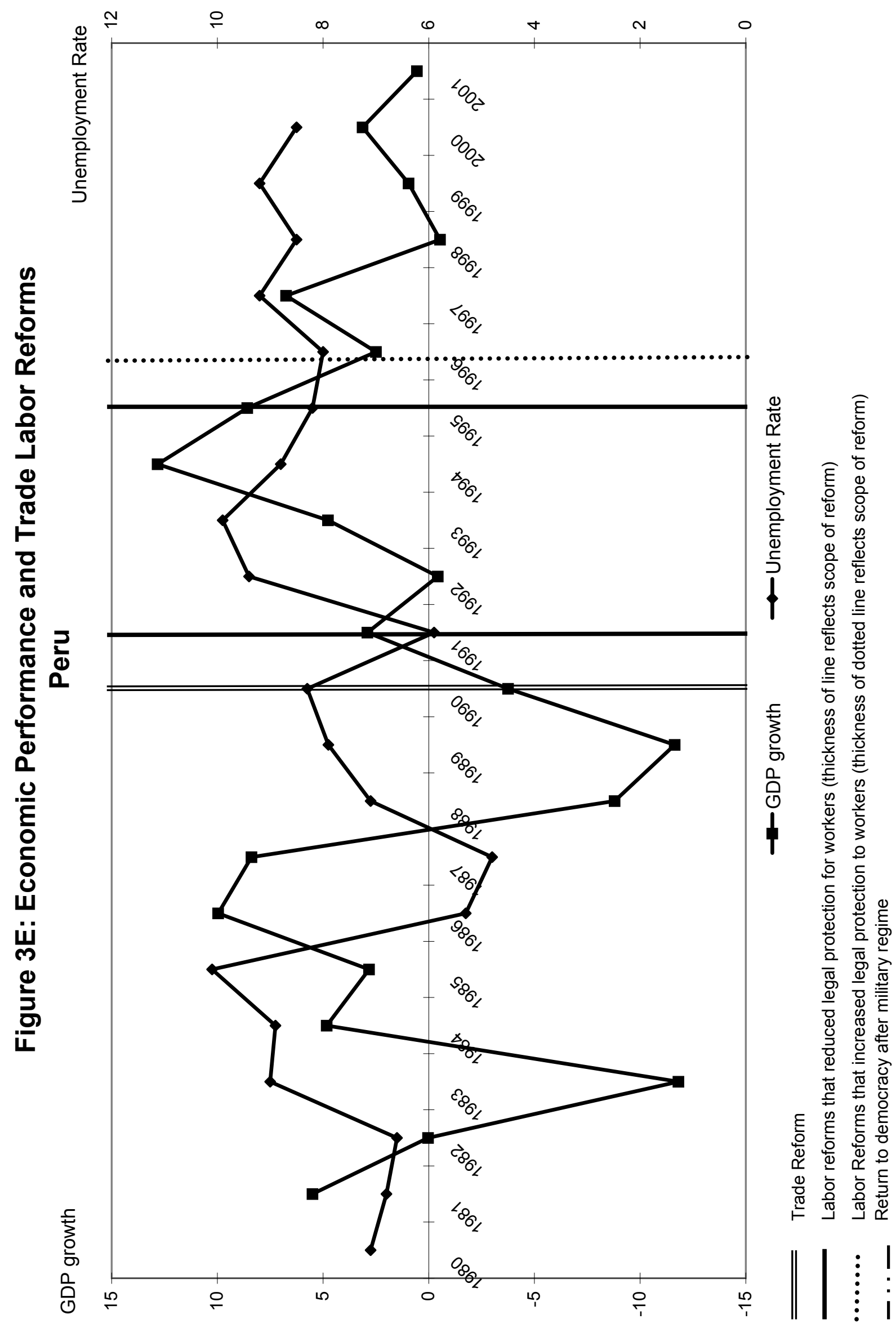




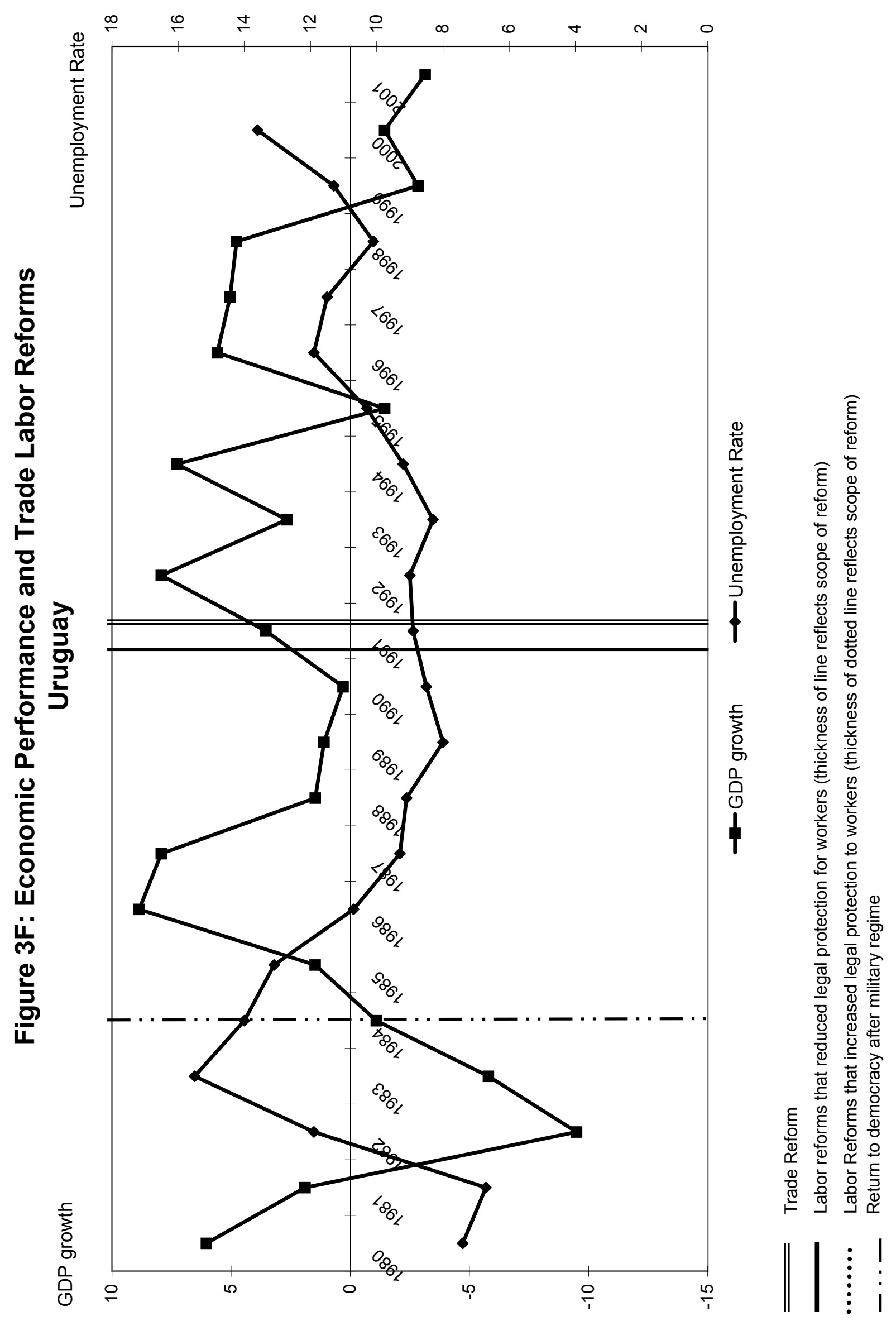




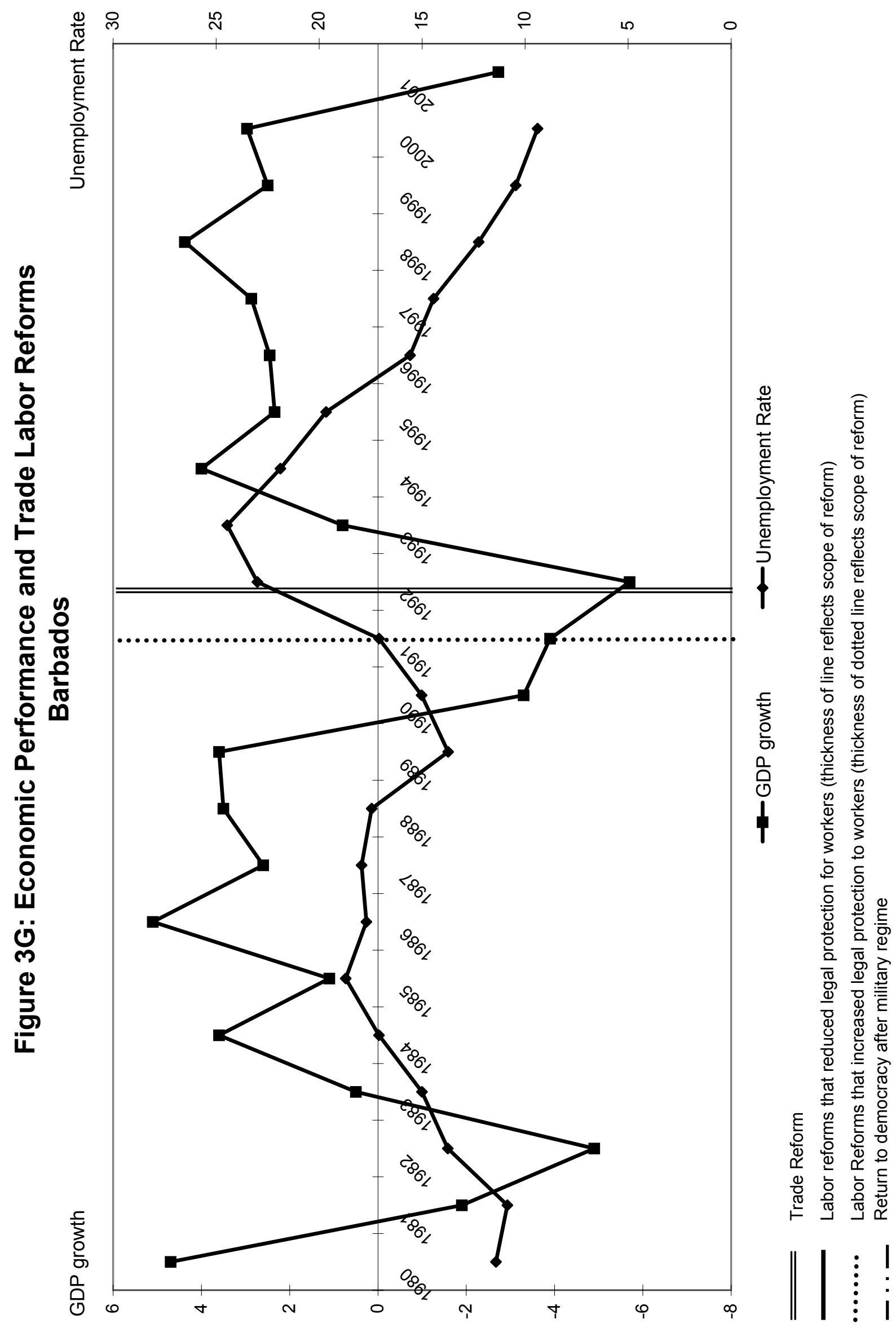




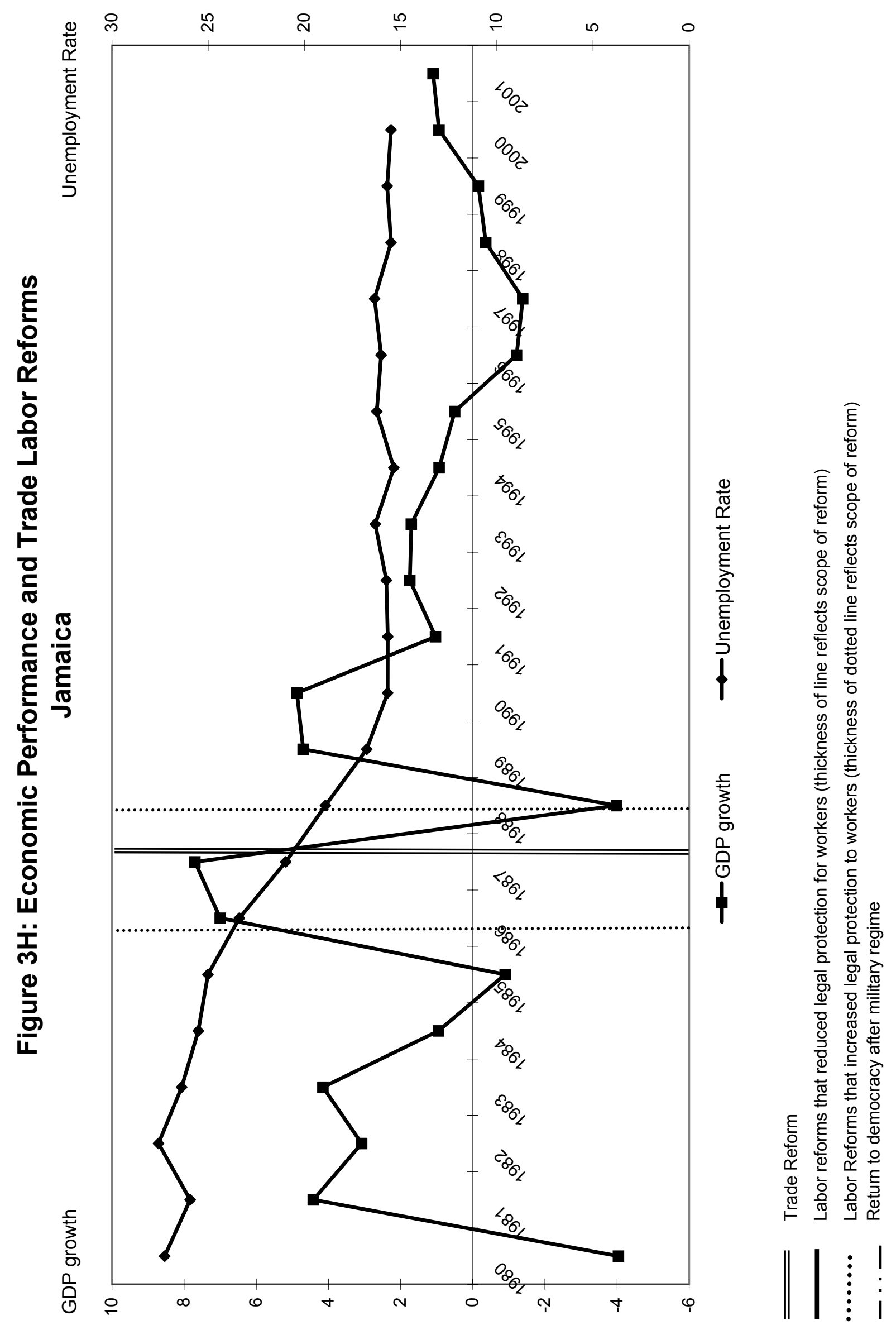




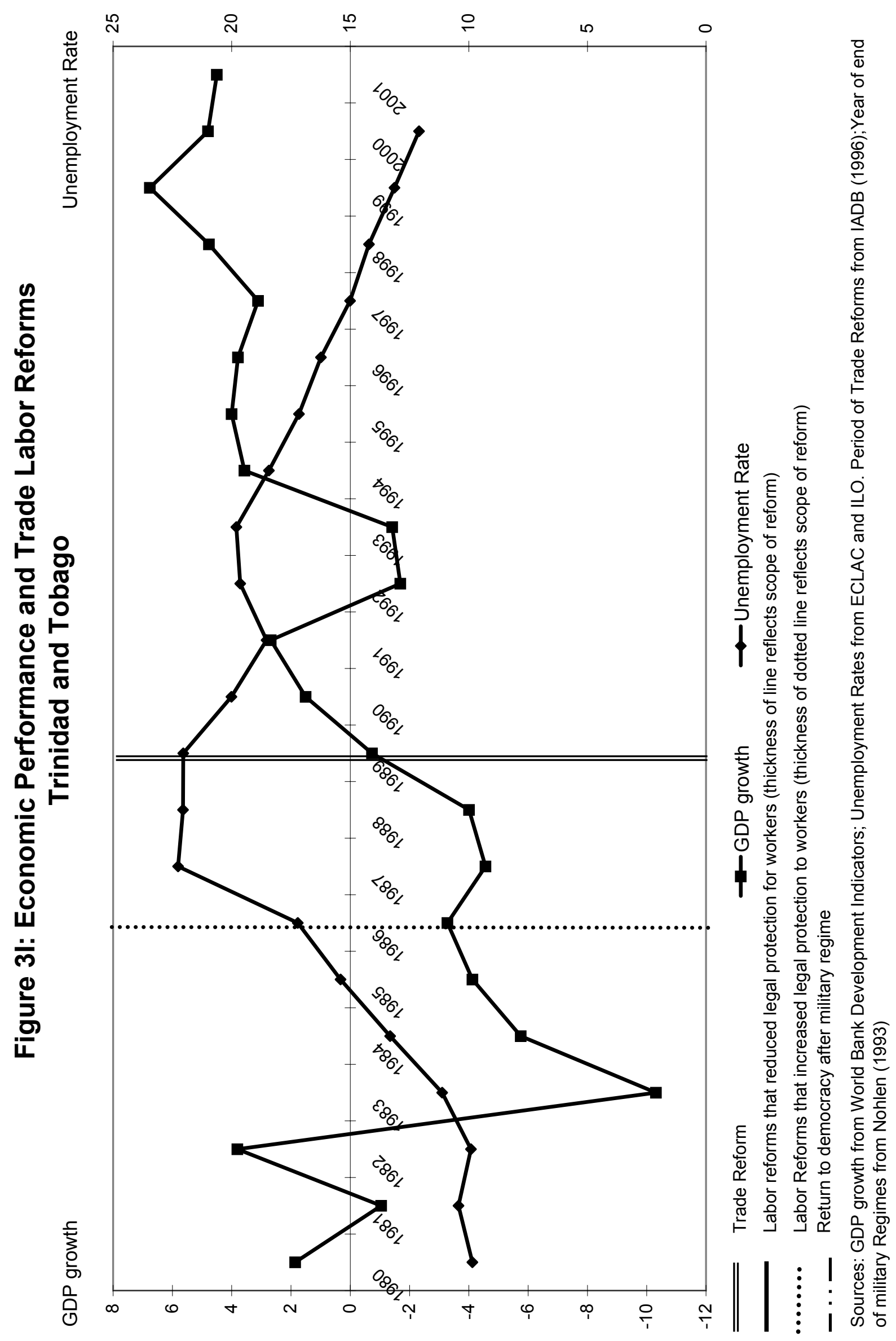




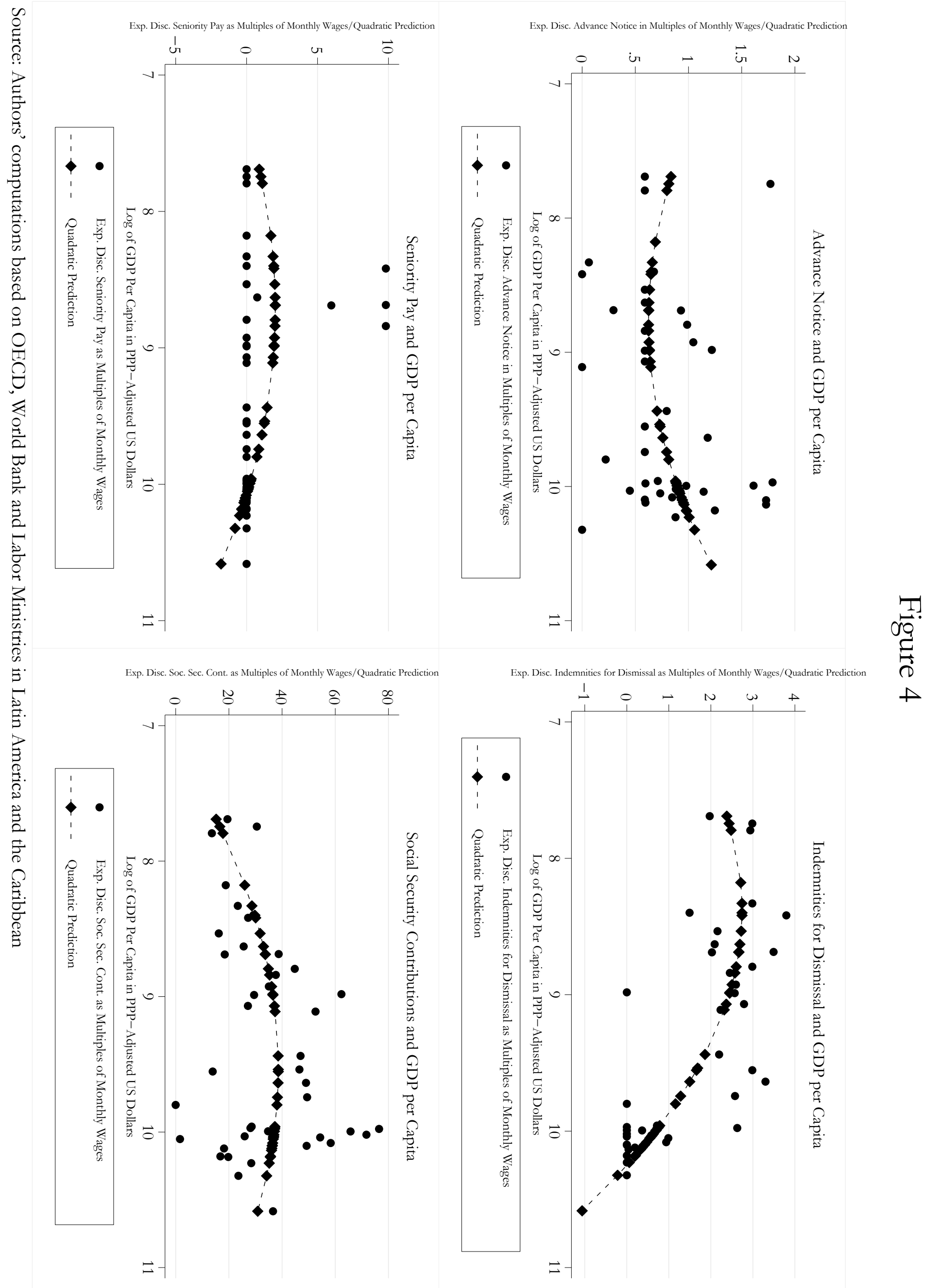




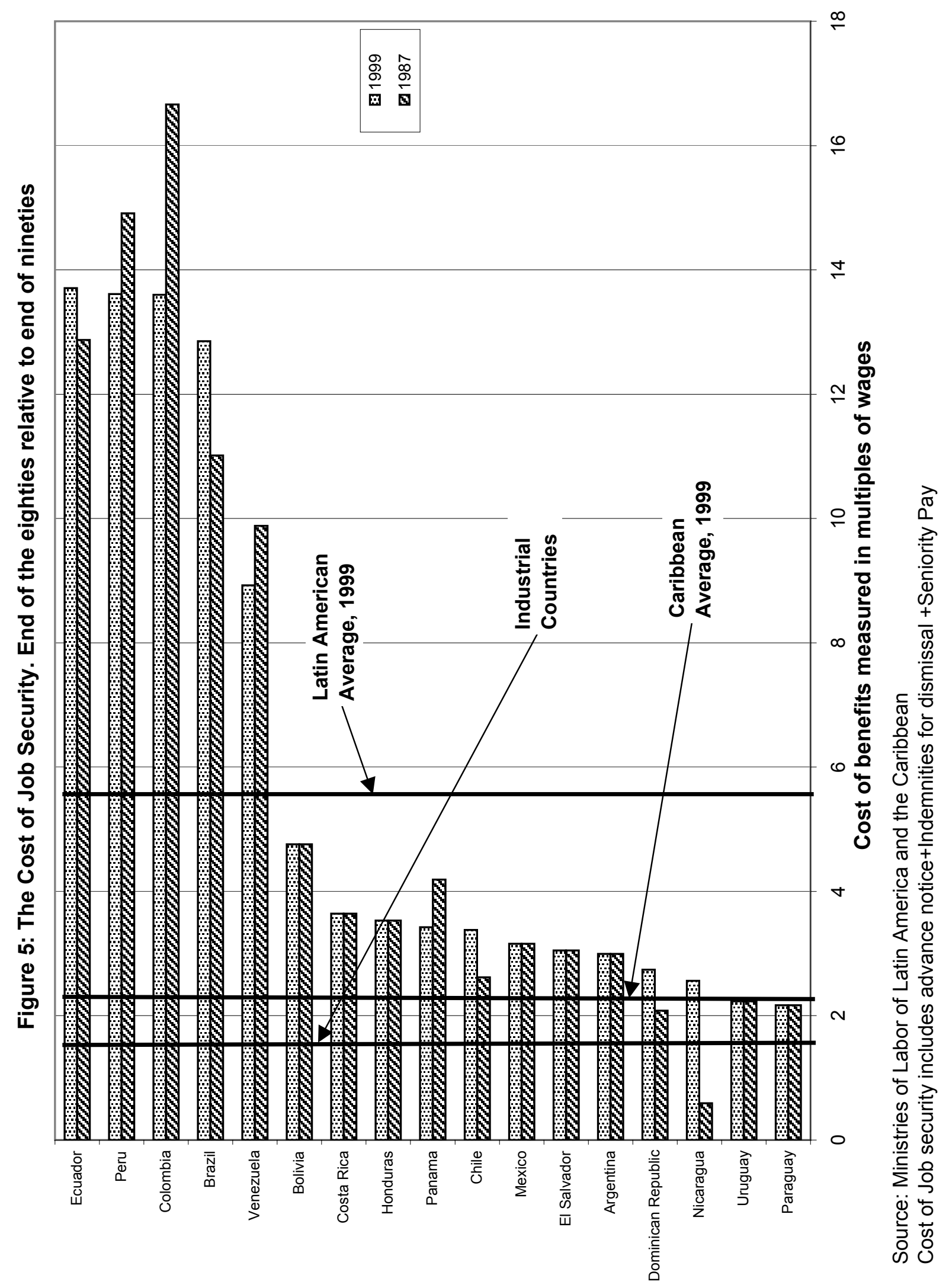




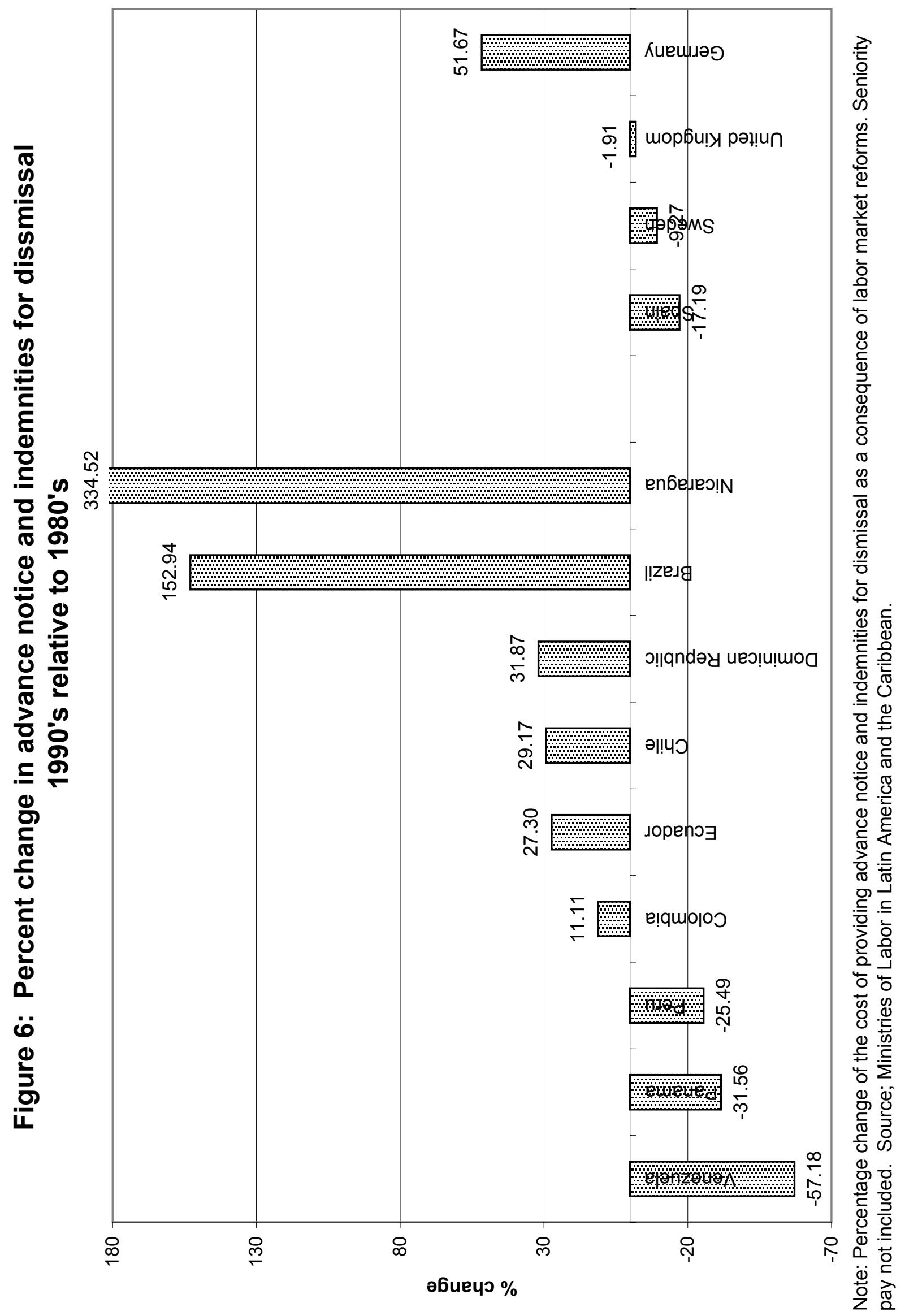




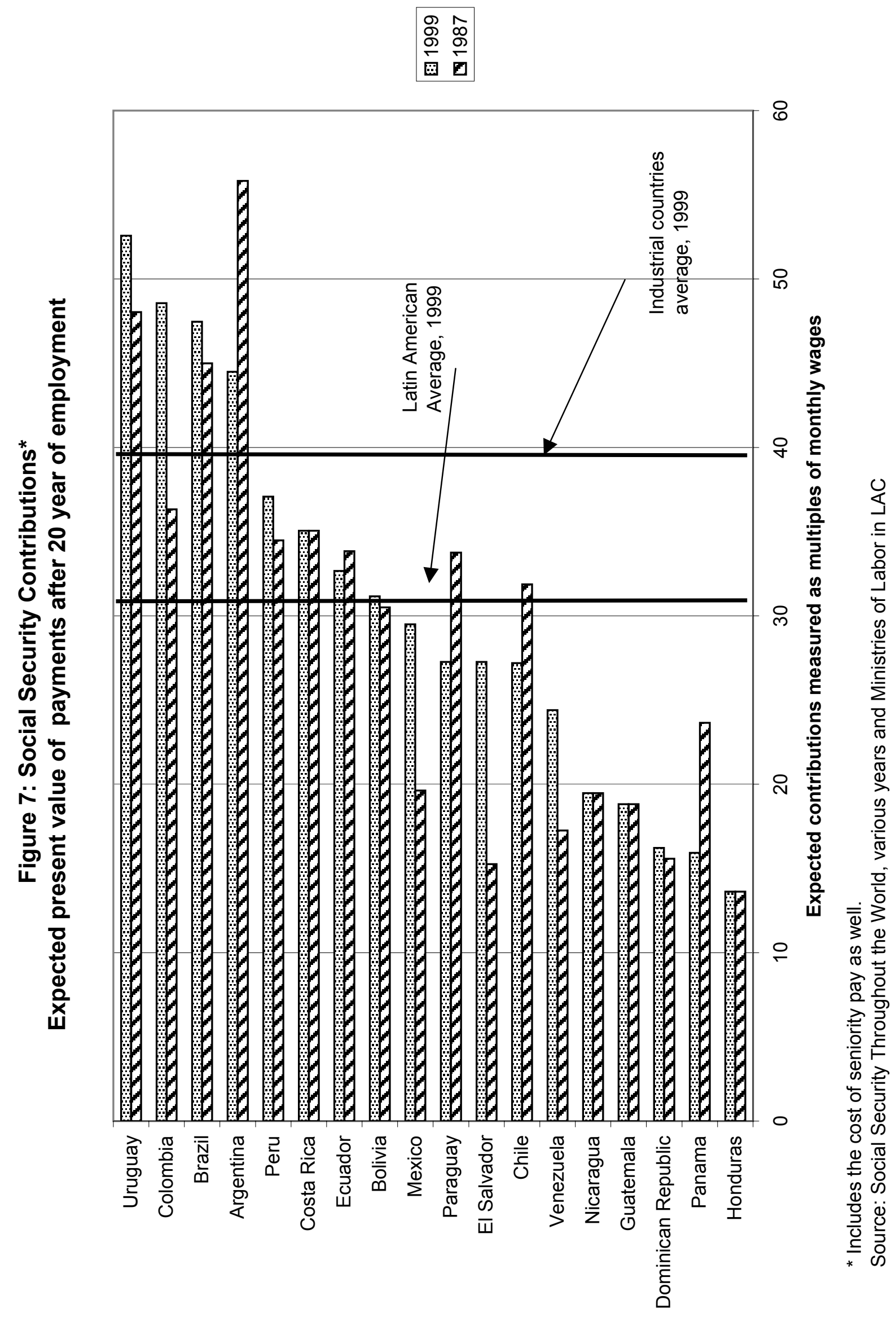




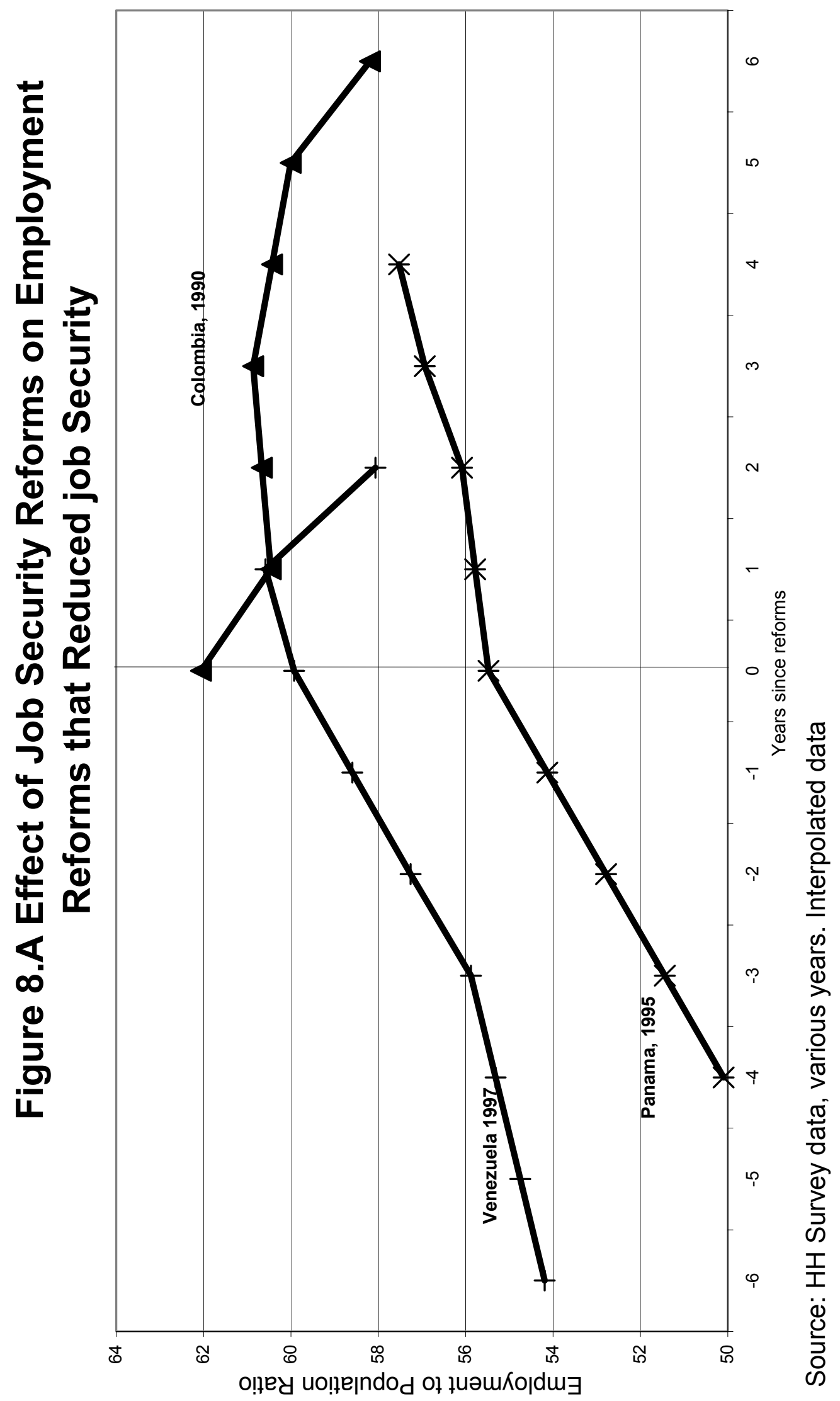




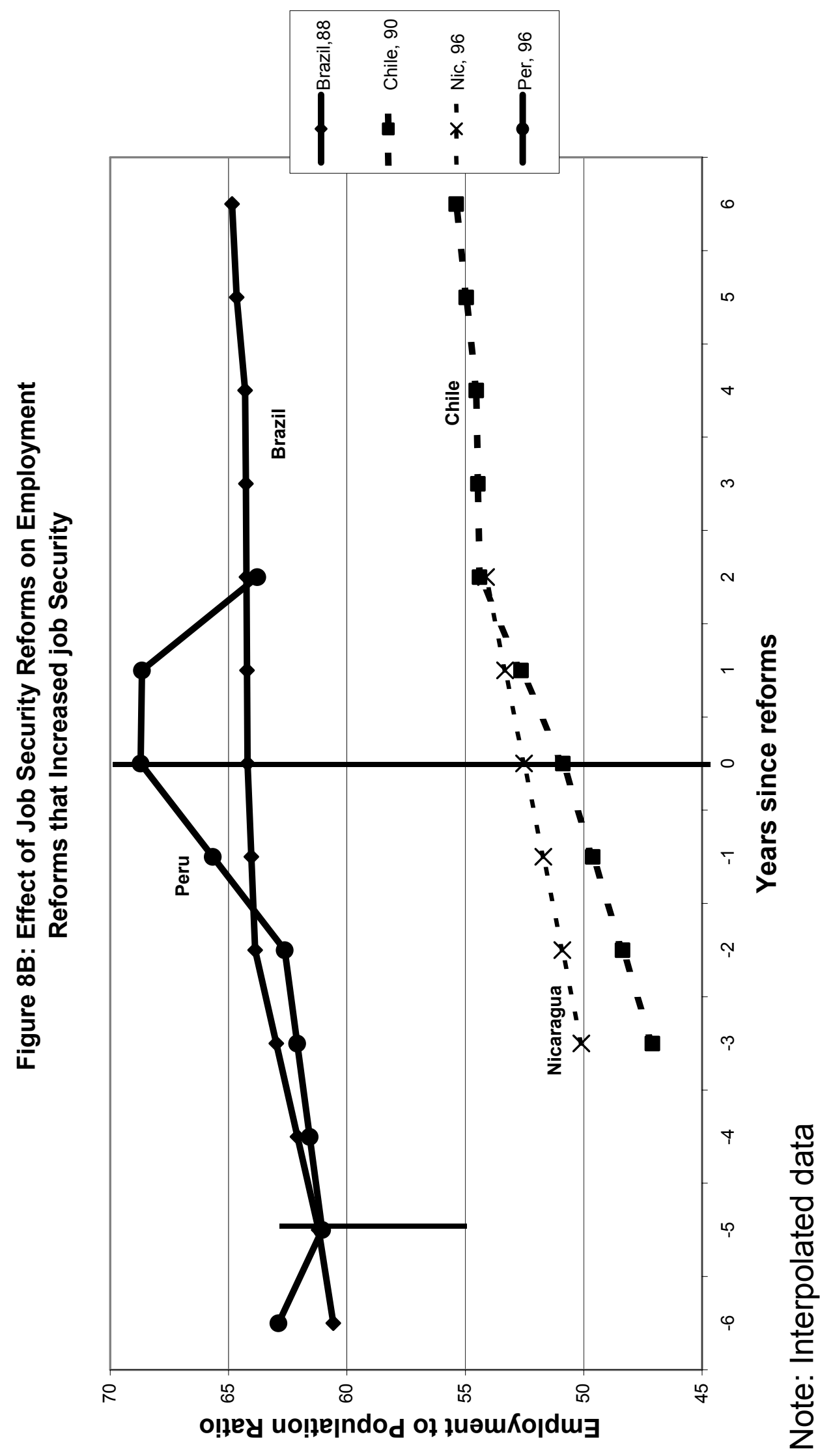




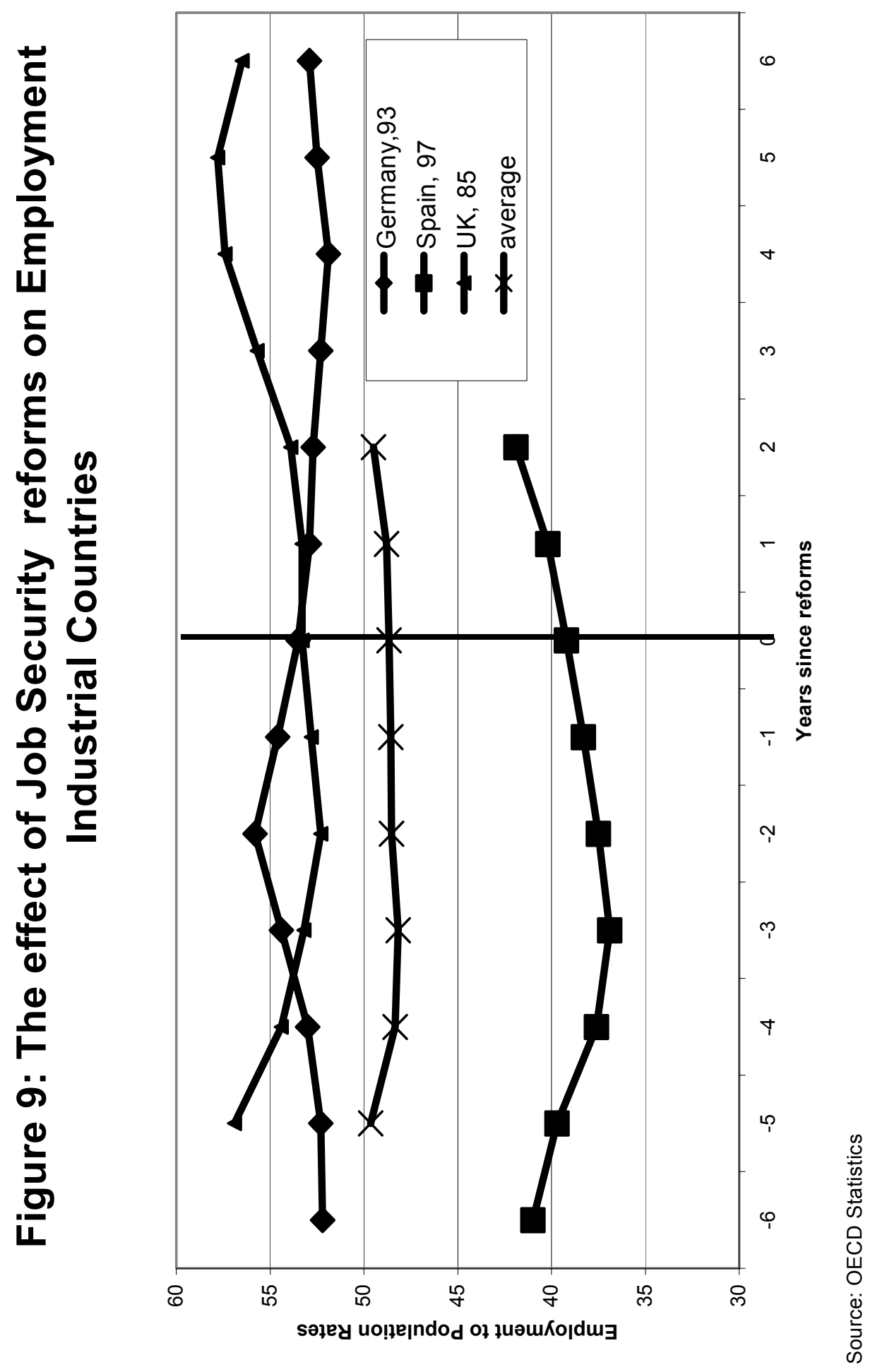

